\title{
Cost and Performance Analysis of Biomass-Based Integrated Gasification Combined-Cycle (BIGCC) Power Systems
}

Kevin R. Craig

Margaret K. Mann

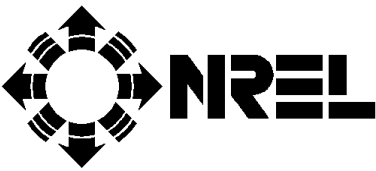

National Renewable Energy Laboratory 1617 Cole Boulevard Golden, Colorado 80401-3393

A national laboratory of the U.S. Department of Energy Managed by Midwest Research Institute for the U.S. Department of Energy under contract No. DE-AC36-83CH10093 


\section{Cost and Performance Analysis of Biomass-Based Integrated Gasification Combined-Cycle (BIGCC) Power Systems}

Kevin R. Craig

Margaret K. Mann

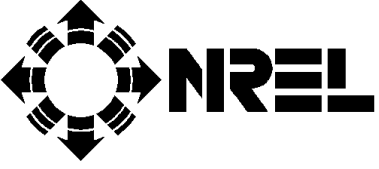

National Renewable Energy Laboratory 1617 Cole Boulevard Golden, Colorado 80401-3393

A national laboratory of the U.S. Department of Energy Managed by Midwest Research Institute for the U.S. Department of Energy under contract No. DE-AC36-83CH10093

Prepared under Task No. BP617171

October 1996 


\section{NOTICE}

This report was prepared as an account of work sponsored by an agency of the United States government. Neither the United States government nor any agency thereof, nor any of their employees, makes any warranty, express or implied, or assumes any legal liability or responsibility for the accuracy, completeness, or usefulness of any information, apparatus, product, or process disclosed, or represents that its use would not infringe privately owned rights. Reference herein to any specific commercial product, process, or service by trade name, trademark, manufacturer, or otherwise does not necessarily constitute or imply its endorsement, recommendation, or favoring by the United States government or any agency thereof. The views and opinions of authors expressed herein do not necessarily state or reflect those of the United States government or any agency thereof.

Available to DOE and DOE contractors from:

Office of Scientific and Technical Information (OSTI)

P.O. Box 62

Oak Ridge, TN 37831

Prices available by calling 423-576-8401

Available to the public from:

National Technical Information Service (NTIS)

U.S. Department of Commerce

5285 Port Royal Road

Springfield, VA 22161

703-605-6000 or 800-553-6847

or

DOE Information Bridge

http://www.doe.gov/bridge/home.html 


\section{EXECUTIVE SUMMARY}

Electric power production from biomass has the potential to make a significant contribution to the power mix in the United States, and to do so with substantially reduced environmental impact. Use of dedicated energy feedstock crops for power production will substantially close the carbon cycle, reduce and stabilize feedstock costs, increase the practical size of biomass power plants, and economically benefit agricultural communities.

To realize these potential contributions however, biomass power systems must be competitive on a cost and efficiency basis. In this report, we describe the cost and performance potential of three biomass-based integrated gasification combined cycle (IGCC) systems. In performing these analyses, we made a conscious decision to examine the potential of such IGCC systems by incorporating advanced technology that either is, or soon will be commercially available and by assuming an " ${ }^{\text {th }}$ plant" basis for costing.

The three gasifier systems chosen for this study were a high pressure air-blown, a low pressure indirectlyheated, and a low pressure air-blown. The high pressure air-blown gasifier was integrated with both the aeroderivative and utility gas turbines studied. Once it was established that a higher efficiency could be achieved with the utility gas turbine, the other two gasifiers were not examined with the aero-derivative turbine. Excess process heat from the gasification and gas turbine sections was used to produce steam for a twopressure steam cycle system. Gas cleanup prior to the gas turbine combustor was accomplished by a tar cracker and either a direct quench and conventional particulate removal operation for the low pressure systems or a hot ceramic candle filter unit for the high pressure system.

Detailed ASPEN process simulations of the systems were developed, and results were used to design, size, and cost the major plant equipment sections. Numerous literature references and previous biomass and coal studies were used to develop overall plant cost information. Standard economic analyses were performed to determine the levelized cost of electricity produced by each system. Additionally, alternative design and operating conditions were tested to optimize the efficiency and reduce the cost of electricity. The table on the following page summarizes the key results. Some of the less dramatic results of the alternative designs are presented in the body of the text.

Another aspect of this assessment was to compare cost and performance results with previous biomass-based IGCC system studies. The differences were analyzed and are presented in this report. When each study was analyzed using the same basic assumptions such as feedstock cost and project contingency, only one of the studies predicted significantly different costs. The impact of advanced utilization technologies currently being developed (advanced turbine systems, fuel cell systems) was also briefly assessed and found to be significant.

The economic viability and efficiency performance of biomass-based IGCC generation technology appear, from this study, to be quite attractive. To realize the full potential of these systems and to take advantage of future developments, it is important to continue development and demonstration of the technologies examined in this report as well as the supporting feedstock supply systems. 


\begin{tabular}{|l|c|c|c|c|c|}
\hline \multicolumn{7}{|c|}{ Summary of Results } \\
\hline & $\begin{array}{c}\text { High pressure } \\
\text { direct gasifier, } \\
\text { aero-derivative } \\
\text { gas turbine }\end{array}$ & $\begin{array}{c}\text { High pressure } \\
\text { direct gasifier, } \\
\text { greenfield } \\
\text { plant }\end{array}$ & $\begin{array}{c}\text { High pressure } \\
\text { direct gasifier, } \\
\text { advanced utility } \\
\text { gas turbine }\end{array}$ & $\begin{array}{c}\text { Low-pressure } \\
\text { indirectly-heated } \\
\text { gasifier, advanced } \\
\text { utility gas turbine }\end{array}$ & $\begin{array}{c}\text { Low-pressure } \\
\text { direct gasifier, } \\
\text { advanced utility } \\
\text { gas turbine }\end{array}$ \\
\hline Output (MWe) & 56 & 56 & 132 & 122 & 105 \\
\hline $\begin{array}{l}\text { Efficiency } \\
(\%, \mathrm{HHV})\end{array}$ & 36.01 & 36.01 & 39.70 & 35.40 & 37.90 \\
\hline $\begin{array}{l}\text { Capital Cost } \\
(\mathrm{TCR}, \$ / \mathrm{kW})\end{array}$ & $\$ 1,588$ & $\$ 1,696$ & $\$ 1,371$ & $\$ 1,108$ & $\$ 1,350$ \\
\hline $\begin{array}{l}\text { Operating } \\
\text { Cost } \\
\text { incl. fuel } \\
(\$ 1,000 / \mathrm{yr})\end{array}$ & $\$ 13,433$ & $\$ 13,675$ & $\$ 28,702$ & $\$ 27,983$ & $\$ 23,442$ \\
\hline $\begin{array}{l}\mathrm{COE} \\
(\notin / \mathrm{kWh} \\
\text { Current } \$)\end{array}$ & 7.91 & 8.20 & 6.99 & 6.55 & \\
\hline $\begin{array}{l}\text { COE } \\
(\notin / \mathrm{kWh} \\
\text { Constant } \$)\end{array}$ & 6.10 & 6.31 & 5.39 & 5.11 & \\
\hline
\end{tabular}




\section{Table of Contents}

Abbreviations and Acronyms

vii

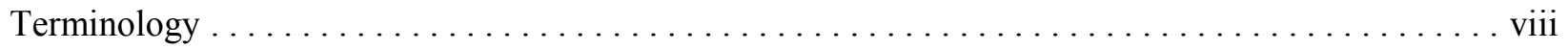

Metric Units of Measurement $\ldots \ldots \ldots \ldots \ldots \ldots \ldots \ldots \ldots \ldots \ldots \ldots \ldots \ldots \ldots \ldots \ldots \ldots \ldots \ldots \ldots \ldots \ldots$

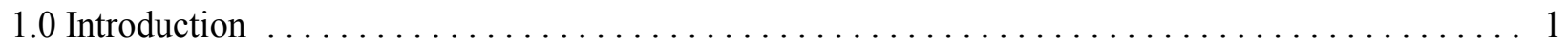

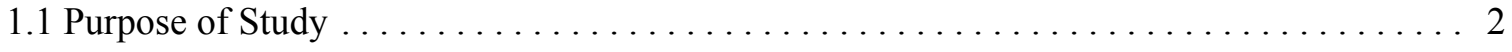

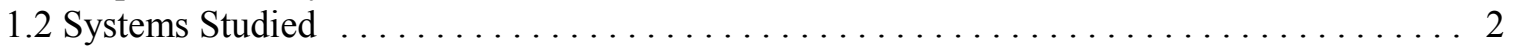

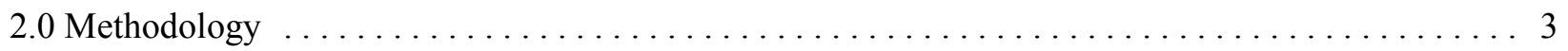

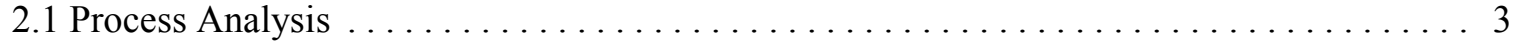

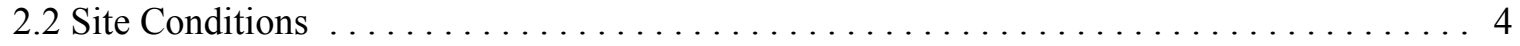

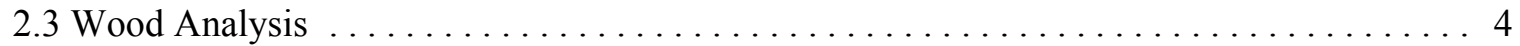

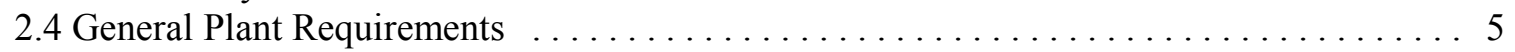

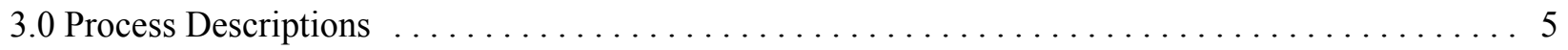

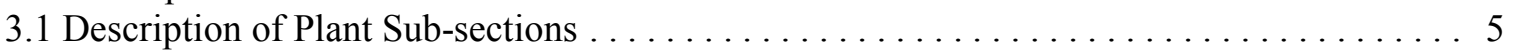

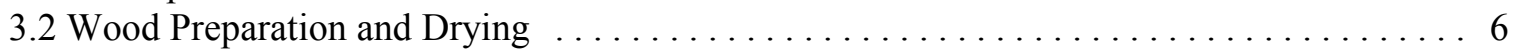

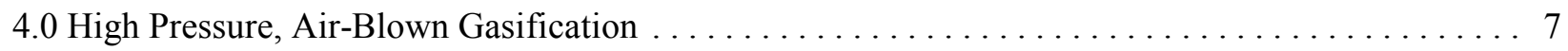

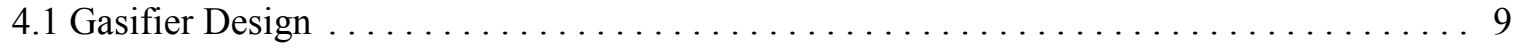

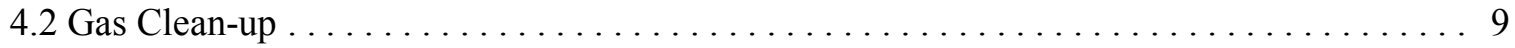

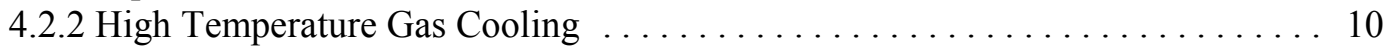

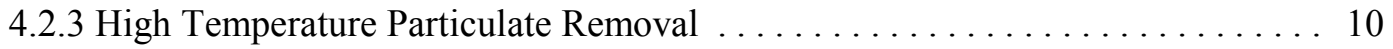

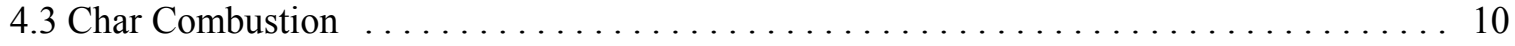

5.0 Low Pressure Indirectly Heated Gasification - The BCL Gasifier $\ldots \ldots \ldots \ldots \ldots \ldots \ldots \ldots$

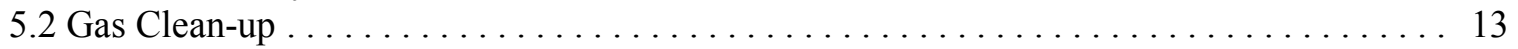

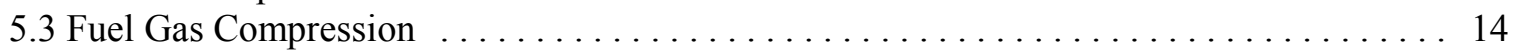

6.0 Low Pressure, Air-Blown Gasification $\ldots \ldots \ldots \ldots \ldots \ldots \ldots \ldots \ldots \ldots \ldots \ldots \ldots \ldots$

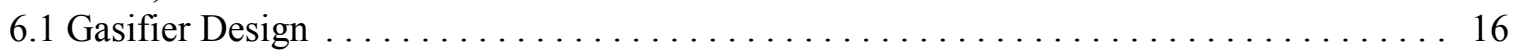

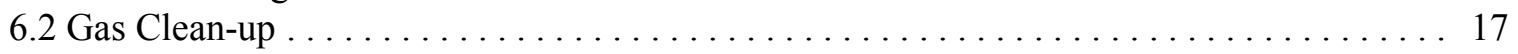

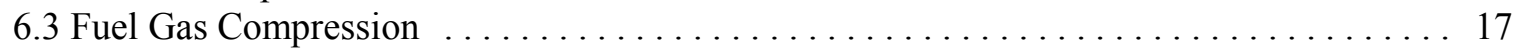

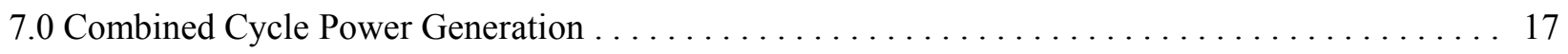

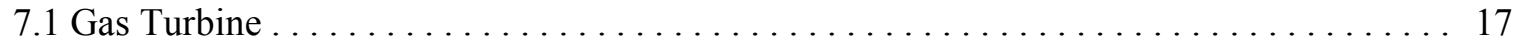

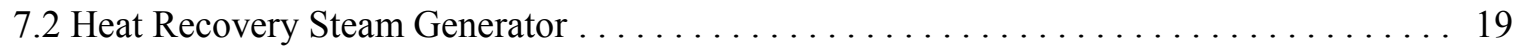

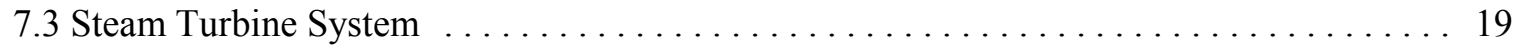

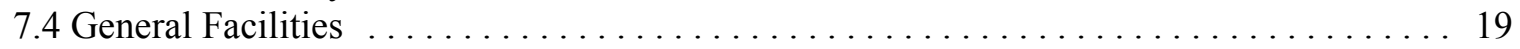

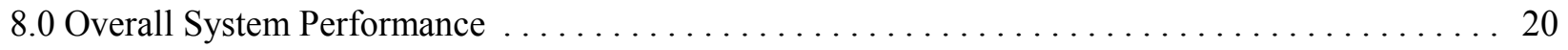




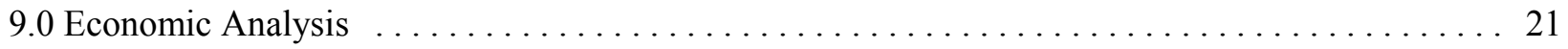

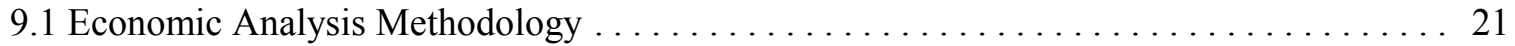

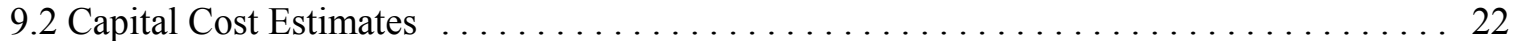

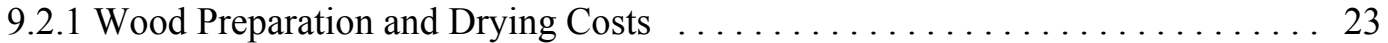

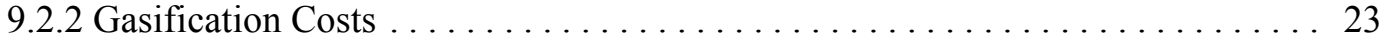

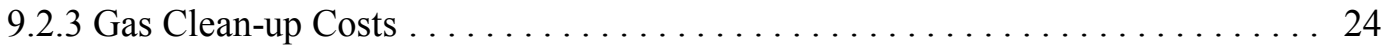

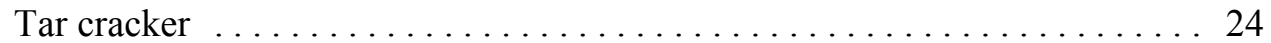

High temperature gas cooling . . . . . . . . . . . . . . . . . . . 24

High temperature particulate removal ................ 24

9.2.4 Compression Costs for Low Pressure Gasifier Systems . . . . . . . . . . . . . 25

9.2.5 Char Combustor Cost for High Pressure Gasifier System . . . . . . . . . . . . 25

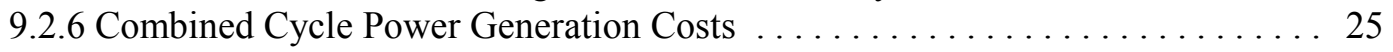

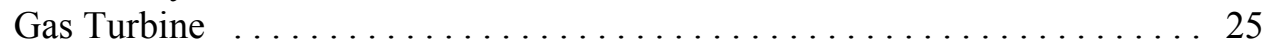

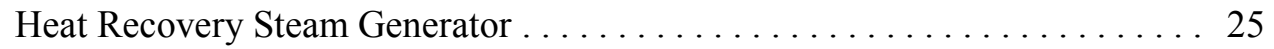

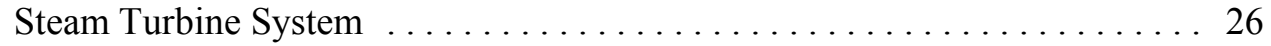

9.3 Total Plant Cost, Total Plant Investment, and Total Capital Requirements . . . . . . . . 26

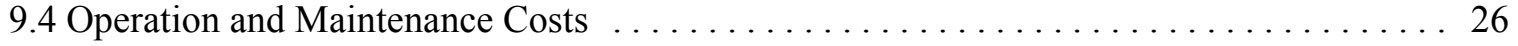

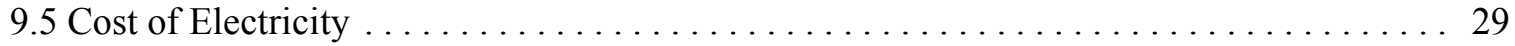

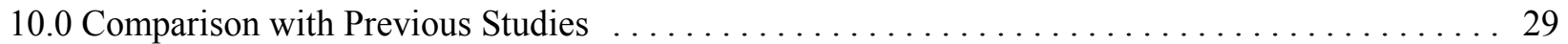

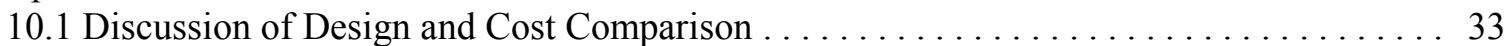

10.1.1 Fuel Costs . . . . . . . . . . . . . . . . . . . . . . . . . . . . 33

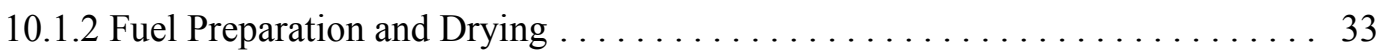

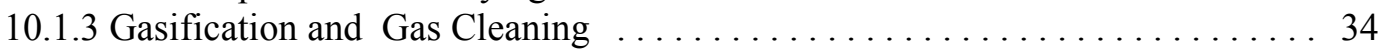

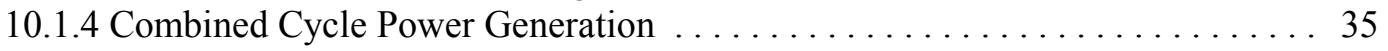

10.1.5 Miscellaneous Cost Differences Between Study . . . . . . . . . . . . 36

10.1.6 Additional Factors Affecting Cost of Electricity . . . . . . . . . . . 37

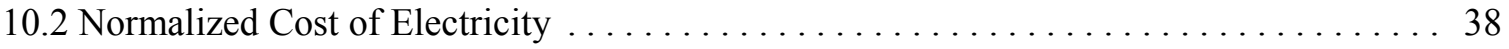

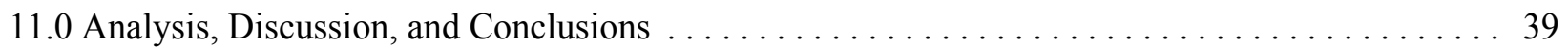

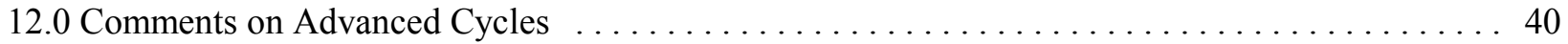




\section{Appendices}

Appendix A: Capital Cost Details for the Systems Studied $\ldots \ldots \ldots \ldots \ldots \ldots \ldots \ldots \ldots \ldots$

Appendix A-1

Capital Cost Details for the High Pressure Gasifier

Integrated with the Aero-Derivative Gas Turbine $\ldots \ldots \ldots \ldots \ldots \ldots \ldots \ldots \ldots \ldots$

Appendix A-2

Capital Cost Details for the High Pressure Gasifier

Integrated with the Utility Gas Turbine $\ldots \ldots \ldots \ldots \ldots \ldots \ldots \ldots \ldots \ldots \ldots \ldots \ldots \ldots \ldots \ldots \ldots$

Appendix A-3

Capital Cost Details for the High Pressure Gasifier

Integrated with the Aero-Derivative Gas Turbine, Greenfield Case . . . . . . . . . . . 45

Appendix A-4

Capital Cost Details for the Low Pressure Indirectly-Heated

Gasifier Integrated with the Utility Gas Turbine $\ldots \ldots \ldots \ldots \ldots \ldots \ldots \ldots \ldots \ldots$

Appendix A-5

Capital Cost Details for the Low Pressure Direct-Fired

Gasifier Integrated with the Utility Gas Turbine $\ldots \ldots \ldots \ldots \ldots \ldots \ldots \ldots \ldots$. . . . . . 47

Appendix B: Details of Biomass IGCC Cost Study Comparison $\ldots \ldots \ldots \ldots \ldots \ldots \ldots \ldots$ 


\section{List of Figures}

Figure 1: Grid Connected Electricity from Biomass $\ldots \ldots \ldots \ldots \ldots \ldots \ldots \ldots \ldots \ldots \ldots \ldots$

Figure 2: General High Pressure BIGCC Schematic $\ldots \ldots \ldots \ldots \ldots \ldots \ldots \ldots \ldots \ldots \ldots \ldots \ldots 7$

Figure 3: Low Pressure Indirect BIGCC Schematic $\ldots \ldots \ldots \ldots \ldots \ldots \ldots \ldots \ldots \ldots \ldots \ldots \ldots 11$

Figure 4: Gasifier Temperature as a Function of Feedstock Moisture Content $\ldots \ldots \ldots \ldots \ldots \ldots$

Figure 5: Low Pressure Direct BIGCC Schematic $\ldots \ldots \ldots \ldots \ldots \ldots \ldots \ldots \ldots \ldots \ldots \ldots$

Figure 6: Cost of Electricity vs. Plant Size From Several Studies $\ldots \ldots \ldots \ldots \ldots \ldots \ldots \ldots \ldots \ldots 31$

Figure 7: Capital Cost of Biomass IGCC Systems vs. Size From Several Studies $\ldots \ldots \ldots \ldots \ldots 31$

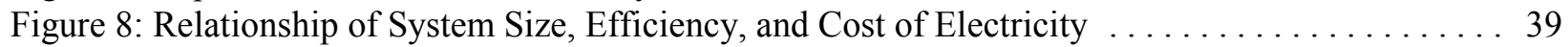

\section{List of Tables}

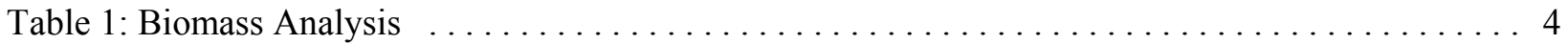

Table 2: Biomass Feed Requirements for Each Analysis $\ldots \ldots \ldots \ldots \ldots \ldots \ldots \ldots \ldots \ldots \ldots \ldots$

Table 3: High Pressure Gasifier Design Parameters and Operating Conditions . . . . . . . . . . . 8

Table 4: High Pressure Gasifier Product Gas Composition $\ldots \ldots \ldots \ldots \ldots \ldots \ldots \ldots \ldots$

Table 5: Indirectly Heated Gasifier Design Parameters and Operating Conditions $\ldots \ldots \ldots \ldots \ldots 12$

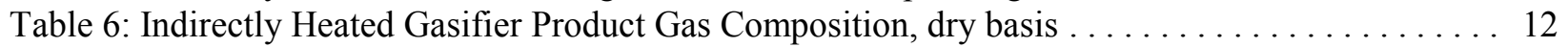

Table 7: Char Composition in the Indirectly-Heated Gasifier Simulation $\ldots \ldots \ldots \ldots \ldots \ldots \ldots \ldots 12$

Table 8: Low Pressure, Direct-Fired Gasifier Design Parameters and Operating Conditions . . . . . 15

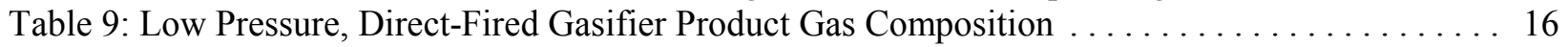

Table 10: Process Data Summary and System Performance Results $\ldots \ldots \ldots \ldots \ldots \ldots \ldots \ldots \ldots$

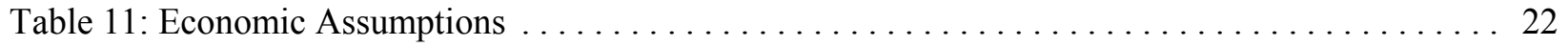

Table 12: Cost Factors Used for Calculation of Total Direct Cost $\ldots \ldots \ldots \ldots \ldots \ldots \ldots \ldots 23$

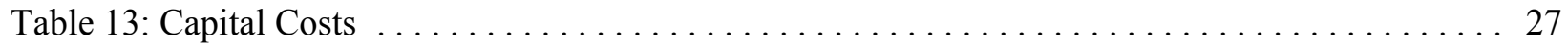

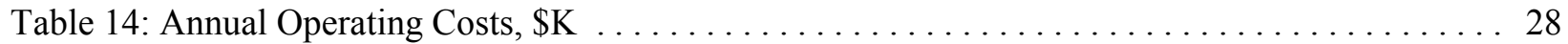

Table 15: Cost and Economic Summary for NREL Cases . . . . . . . . . . . . . . . . . . 29

Table 16: Summary of Technical and Cost Data from Four Biomass IGCC Studies . . . . . . . . 32

Table 17: Fuel Costs of Four Biomass IGCC Studies $\ldots \ldots \ldots \ldots \ldots \ldots \ldots \ldots \ldots \ldots \ldots \ldots \ldots$

Table 18: Fuel Preparation Costs of Four Biomass IGCC Studies $\ldots \ldots \ldots \ldots \ldots \ldots \ldots \ldots \ldots \ldots$

Table 19: Installed Costs of Gasification and Gas Cleaning Sections $\ldots \ldots \ldots \ldots \ldots \ldots \ldots \ldots$

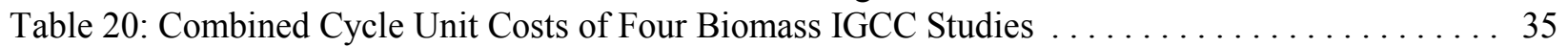

Table 21: Balance of Plant and Contingency Estimates of Four Biomass IGCC Studies . . . . . . 36

Table 22: Total Capital Investment and Direct Costs in Four Biomass IGCC Studies . . . . . . . . . 37

Table 23: Normalized Cost Comparison of Four Biomass IGCC Studies $\ldots \ldots \ldots \ldots \ldots \ldots \ldots$ 


\section{Abbreviations and Acronyms}

ASPEN - Advanced System for Process ENgineering

BCL - Battelle Columbus Laboratories

BIGCC - biomass integrated gasification combined cycle

CCT - Clean Coal Technology Program

$\mathrm{CO}$ - carbon monoxide

$\mathrm{CO}_{2}$ - carbon dioxide

COE - cost of electricity

DCFROR - discounted cash flow rate of return

DFSS - dedicated feedstock supply system

DOE - Department of Energy

EPRI - Electric Power Research Institute

GJ - gigajoule

HHV - higher heating value

HRSG - heat recovery steam generator

IGCC - integrated gasification combined cycle

IGT - Institute of Gas Technology

IRR - internal rate of return

$\mathrm{kPa}$ - kilopascal

$\mathrm{kWh}$ - kilowatt-hour

LHV - lower heating value

MAF - moisture and ash free

MMBtu - million British thermal units

METC - Morgantown Energy Technology Center

$\mathrm{MW}_{\mathrm{e}}$ - megawatts, electrical

NREL - National Renewable Energy Laboratory

ORNL - Oak Ridge National Laboratory

PDU - process development unit

PFBC - pressurize fluidized bed reactor

SCFD - standard cubic feet per day

TAG - Technical Assessment Guide, published by EPRI

$\mathrm{t}$ - ton

TCR - total capital requirements

TPC - total plant cost

TPI - total plant investment

T- Metric tonne 


\section{Terminology}

Three gasifiers were analyzed for this study. The following descriptions are used interchangeably for each gasifier in this report:

IGT gasifier $=$ high pressure, air-blown gasifier $=$ high pressure gasifier $=$ high pressure direct-fired gasifier $=$ high pressure direct gasifier.

$\mathrm{BCL}$ gasifier $=$ low pressure, indirectly-heated gasifier $=$ low pressure indirect gasifier.

Low pressure, air-blown gasifier $=$ low pressure direct-fired gasifier $=$ low pressure direct gasifier.

\section{Metric Units of Measurement}

In accord with recommendations from the Department of Energy, all results from this study are reported in metric units. Occasionally, the English system equivalent is stated in parenthesis. Below are the metric units used in this report with the corresponding conversions to English units.

Energy: $\quad$ gigajoule $(\mathrm{GJ})=0.9488 \mathrm{MMBtu}$

kilowatt-hour $(\mathrm{kWh})=3,414.7 \mathrm{Btu}$

Mass: $\quad$ kilogram $(\mathrm{kg})=2.20462$ pounds

metric tonne $(\mathrm{T})=1 \mathrm{Mg}=1.10231$ ton

Power: $\quad$ kilowatt $(\mathrm{kW})=1.341 \mathrm{hp}$

Pressure: $\quad$ kilopascals $(\mathrm{kPa})=0.145$ pounds per square inch

Temperature: $\quad{ }^{\circ} \mathrm{C}=\left({ }^{\circ} \mathrm{F}-32\right) / 1.8$

Volume: $\quad$ cubic meter $\left(\mathrm{m}^{3}\right)=264.17$ gallons 


\subsection{Introduction}

Currently, there are approximately $8.5 \mathrm{GW}$ of grid-connected biomass electrical generating capacity in the U.S., including that from landfill gas and municipal solid waste (see Figure 1). Unfortunately, a substantial fraction of this existing capacity employs relatively unsophisticated and inefficient direct steam technology. Average efficiencies for existing systems are less than $25 \%$. As a consequence, the size of a given biomass power installation historically has been limited by these low efficiencies and the amount of fuel within an economical transportation radius. The resulting low output yields a high capital cost for these systems on a dollars per kilowatt basis $(\$ / \mathrm{kW})$. A number of recent developments are changing the nature and constraints of the biomass power option, however.

Significant technical advancements are being made that will allow for substantially increased utilization efficiency of biomass as a fuel. Advanced gas turbine and combined cycle technology is being commercially deployed and demonstrated with natural gas as well as solid fuels such as coal through the use of gasification technology. Biomass gasification technologies are also being developed and demonstrated. Linking these conversion and utilization processes will nearly double current biomass electrical generation efficiencies. Concurrently, DOE, NREL, and ORNL are actively pursuing development and demonstration of Dedicated Feedstock Supply Systems (DFSS). Such systems would allow operation of plants requiring as much as 2000 dry T/day of biomass feed. The combination of advancing technology and improved fuel supply will increase the feasible biomass power plant size into a range attractive to utilities, and thus expand the market for biomass power beyond the independent power producers and co-generators who have, to date, been the principal players in the biomass power industry.

Moreover, these biomass power systems will further leverage research dollars by directly and substantially benefitting from the technological advances being made by government and industry funded gas turbine and fuel cell development programs. These utilization technologies are the subject of substantial development efforts, and are being demonstrated in integrated systems with coal gasifiers under the Clean Coal Technology Program.

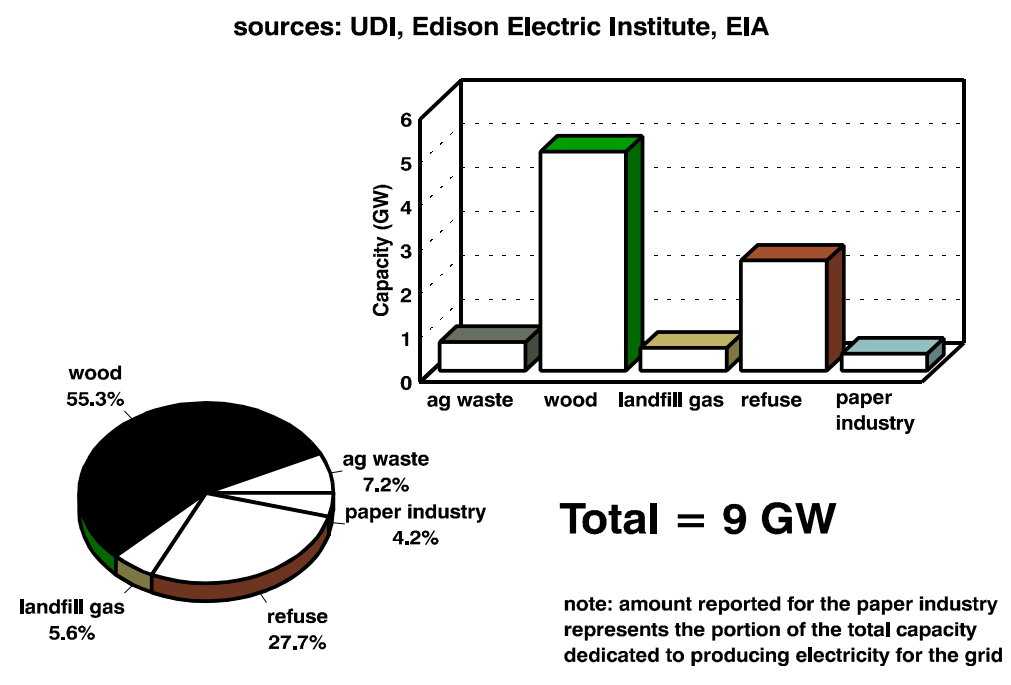

Figure 1: Grid Connected Electricity from Biomass 


\subsection{Purpose of Study}

The purpose of this study was to determine the efficiency and cost of electricity of IGCC systems incorporating biomass gasification technology. The systems we examined incorporate state-of-the-art, commercially available aero-derivative and utility gas turbine technology as well as scale-appropriate modern steam cycle technology. The resulting performance and cost numbers indicate the commercial potential for these systems, and define areas for continued and focused research. We also examined different options for gas cleaning prior to combustion in the gas turbine combustor, and compared our results to previous studies on this subject.

\subsection{Systems Studied}

ASPEN simulations were performed on three biomass IGCC systems: an air-blown (i.e. direct-fired) pressurized fluidized bed gasifier of the type under development by the Institute of Gas Technology (IGT), the Battelle Columbus Laboratory (BCL) low pressure indirectly-heated biomass gasifier, and an air-blown low pressure gasifier similar to that developed by Thermiska Processor AB (TPS) in cooperation with ABBFlakt. Process development unit (PDU) experimental results, where available, provided the basis for gasifier performance predictions. A high degree of process integration between the gasifier and combined cycle was incorporated to maximize system efficiency. The combined cycles investigated were based on aeroderivative and state-of-the-art utility gas turbines of appropriate sizes. To make a direct comparison of different combined cycle systems, the high pressure direct-fired gasifier was integrated with both an aeroderivative gas turbine and an utility gas turbine. The aero-derivative gas turbine selected for this study was the General Electric LM-5000PC. This unit has a higher pressure ratio (24.8) and firing temperature (in excess of $1150^{\circ} \mathrm{C}$ ) than the utility machines selected for most previous biomass IGCC studies. The utilityscale gas turbine selected was the GE MS-6101FA, an advanced turbine that moves GE's "F" technology (high firing temperature, high efficiency) down to a $70 \mathrm{MW}$-class machine.

Because of lower overall system efficiencies (as compared with the utility turbine case) and higher fuel pressures required, cases integrating the low pressure gasifiers with the LM-5000 turbine were not considered. All systems employing the utility turbine used a two-pressure reheat steam cycle. The LM-5000 case used a small, non-reheat steam cycle. Gas cleanup in all cases included a tar cracker to reduce the quantity of higher hydrocarbon species in the gas, followed by gas cooling via direct or indirect quench to condense alkali species. For the high pressure gasifier, a hot ceramic candle filter of the type being offered by Westinghouse and being demonstrated under the Clean Coal Technology Program was used to remove particulate matter including these condensed alkali compounds. In this case, the quench step cooled the gas down to less than $538{ }^{\circ} \mathrm{C}$. Particulate removal in the low-pressure gasifier cases was accomplished with cyclones and a fabric filter. The direct quench that follows in these latter cases reduces the fuel gas temperature to $96^{\circ} \mathrm{C}$ in preparation for compression.

Other alternate designs that were studied include greenfield plant construction instead of an existing plant site basis, indirect cooling of the synthesis gas, various levels of humidification of the syngas, and different moisture levels of the feedstock. It should be noted that not all of these variations were examined with each gasifier combined cycle system. Performance, cost, and economic data were developed for each of the cases tested, and are presented in this report. 


\subsection{Methodology}

The intent of this study was to evaluate the ultimate potential for application of IGCC technology to biomassbased power systems of large scale (>30 MWE). Therefore, the plant designs examined were assumed to be for mature, " $\mathrm{n}$ th -plant" systems. The aggressive sparing and redundancies typically utilized for "firstplant" designs and the attendant cost associated with such an approach were not applied to the systems examined here. However, the technology and equipment utilized in all of the system designs is currently, though not in all cases commercially, available. In some cases, the technology selected for these systems is under development for increased reliability, availability, and maintainability. However, projected technological advances that may result from on-going research were not included or assumed.

The base year of 1990 was chosen for cost and economic analyses in this study. In part, this reference year was chosen to facilitate comparison of our costs with previous studies in this area.

\subsection{Process Analysis}

Detailed process models were developed using the Advanced System for Process ENgineering (ASPEN/SP) process simulator to evaluate the performance of the three biomass IGCC systems. The material and energy balance results of these simulations were used to size and cost major pieces of equipment from which the resulting cost of electricity was calculated. As part of this development, data from PDU operation of the IGT and BCL gasifiers were regressed and incorporated into a user-specified yield reactor. Detailed information on gasifier operation and performance at a variety of conditions was not available for the low-pressure direct gasifier. Therefore, this case utilized a quasi-equilibrium model and reactant ratios developed from limited data contained in a Lurgi report on fluidized bed gasification of biomass[1].

Gas turbine performance when utilizing low energy content biomass derived fuel gas was estimated based on the operating parameters (air flow, pressure ratio, firing temperature, outlet temperature) of the selected gas turbine [2],[3]. A simulation was developed that matches its performance (output, heat rate) on natural gas fuel by "tuning" the efficiency of the various compression and expansion stages as well adjusting heat losses, cooling air extraction etc. Utilizing these same "tuning" parameters, the resulting turbine model was incorporated, along with the biomass gasifier and cleanup section models, into an overall gasification combined cycle simulation. The simulation was configured such that the amount of biomass fed to the system was calculated based on the amount of gaseous fuel required by the gas turbine to achieve its design firing temperature. Changes in the gas turbine output and efficiency because of the increased mass flow of the low energy content gas and the higher fuel gas temperature are thus roughly predicted. This approach has been employed in numerous studies performed at the Morgantown Energy Technology Center (METC) for coal-based IGCC systems. This prediction method has also been validated, within certain limits, by results obtained by turbine manufacturers and engineering firms that have prepared detailed designs of the such systems. It must be realized, especially in the air-blown gasifier cases, that modification of the gas turbine combustor may be required in order to efficiently combust the low calorific value fuel gas produced. The design limits of the turbine compressor must also be kept in mind when mass flow through the turbine section is increased. Such a scenario arises, again, due to the reduced (compared to natural gas) chemical energy content of the fuel gas produced from biomass.

The simulation calculates the overall biomass-to-electricity efficiency for the system based on total feed to the system and the net electrical power produced. The major auxiliary equipment items (feed water pumps, boost compressor, blowers, etc.) are explicitly included in the simulation, and their power requirements 
subtracted from the gross plant output. A 3\% charge was taken against this preliminary net power (gross minus major equipment) to account for balance of plant electrical power including wood handling and drying.

\subsection{Site Conditions}

Since this was not a site specific design, ranges of ambient conditions were not available. Therefore, International Standards Organization (ISO) conditions $\left(15^{\circ} \mathrm{C}, 1\right.$ bar atmospheric pressure, $60 \%$ relative humidity) were assumed as the ambient conditions for this evaluation. Air fed to the plant was assumed to be composed of $20.73 \mathrm{~mol} \%$ oxygen, $78.22 \mathrm{~mol} \%$ nitrogen, $1.02 \mathrm{~mol} \%$ water, and $0.03 \mathrm{~mol} \%$ carbon dioxide.

\subsection{Wood Analysis}

The biomass used in each analysis was that used most extensively in testing each gasifier. Wisconsin maple wood chips have been tested at a number of gasifier conditions in the IGT RENUGAS ${ }^{\circledR} 9$ T/day process development unit (PDU), and are therefore used in the high pressure simulations. According to tests at BCL, the biomass used for the low pressure indirectly-heated gasifier simulation is typical of woody biomass such as hybrid poplar. Wisconsin maple was also used as the feedstock in the low pressure direct gasifier simulation. The ability to feed biomass to gasification systems, high and low pressure, has been demonstrated in experimental work at a variety of scales. Detailed analyses of the feedstock, product gas, and solid residues are available from experimental data for the IGT and BCL gasifiers. For the low-pressure direct gasifier case, feed data is available and char and product gas composition is estimated. In the ASPEN simulations, biomass and char were simulated as non-conventional components; the elemental and property analysis for each biomass type are shown in Table 1. The heat of combustion was calculated by adjusting the standard ASTM correlation for biomass.

\begin{tabular}{|l|c|c|}
\hline \multicolumn{3}{|c|}{ Table 1: Biomass Analysis } \\
\hline & Wisconsin Maple & Hybrid Poplar \\
\hline $\begin{array}{l}\text { Ultimate Analysis } \\
\text { (weight \%, dry basis) }\end{array}$ & & \\
\hline Carbon & 49.54 & 50.88 \\
\hline Oxygen (by difference) & 43.73 & 41.90 \\
\hline Hydrogen & 6.11 & 6.04 \\
\hline Nitrogen & 0.10 & 0.17 \\
\hline Sulfur & 0.02 & 0.09 \\
\hline Chlorine & 0.00 & 0.00 \\
\hline Ash & 0.50 & 0.92 \\
\hline $\begin{array}{l}\text { Heat of combustion, } \\
\text { HHV, Btu/lb, dry basis }\end{array}$ & 8,476 & 8722 \\
\hline Moisture, as received & $38 \%$ & $50 \%$ \\
\hline
\end{tabular}




\subsection{General Plant Requirements}

With the exception of the greenfield analysis of the high pressure direct gasifier, the plants examined are assumed to be located at or near an existing generating facility and to share facilities such as land and an electrical substation. Additionally, all plants are assumed to be in close proximity to roads or railroad spurs adequate for delivery of the biomass feedstock. This is likely to be true when a dedicated feedstock supply system (DFSS) is employed since the power plant would be sited near the center of the agricultural area representing its biomass "shed". In addition to the major process areas and equipment discussed later in the report, the following items and systems are assumed to be part of the plants evaluated in this study: cooling water systems, plant and instrument air, potable and utility water, effluent water treatment, flare system, fire-water system, interconnecting piping, buildings, lighting, computer control system, and electrical system.

\subsection{Process Descriptions}

\subsection{Description of Plant Sub-sections}

The biomass-based IGCC electric generating plants considered in this study consist of the following process sections:

- $\quad$ Fuel receiving, sizing, preparation, and drying

- $\quad$ Truck unloading system

- $\quad$ Wood yard and storage

- $\quad$ Sizing and conveying system

- $\quad$ Dryers

- $\quad$ Live storage area

- $\quad$ Gasification and gas cleaning (Gasification Island)

- $\quad$ Wood feeding unit

- Gasifier

- Char combustion and air heating

- $\quad$ Primary cyclone

- Tar cracker

- $\quad$ Gas quench

- $\quad$ Particulate removal operation

- $\quad$ Power Island

- $\quad$ Gas turbine and generator

- $\quad$ Heat Recovery Steam Generator (HRSG)

- $\quad$ Steam turbine and generator

- $\quad$ Condenser, cooling tower, feed water and blowdown treating unit

- General plant utilities and facilities 
All systems simulated incorporate a fairly high level of integration between plant sections. In each system examined, a char combustor is used to convert any un-gasified carbon. The resulting energy provides pre-heating for the gasifier steam and air (where required), as well as heat for the biomass drying. In actual practice, carbon conversion in the direct gasifiers may be sufficiently high that a separate char combustor is not required. In the indirectly-heated gasification system, the char is combusted to heat sand which is circulated to the gasifier. There, the hot sand provides heat for the endothermic gasification reactions.

Air for the direct-fired gasifiers was removed from the gas turbine compressor discharge scroll and boosted or let down in pressure, as appropriate, with a compressor or turbine. This air extraction is necessary to avoid significantly increased mass flow in the expansion section of the gas turbine, and thus compressor surge. Without air extraction, turbine mass flow would be increased due to high fuel gas flows necessitated by the fuel gas's low energy content. Gasification steam, where required, was extracted from an appropriate location in the steam cycle.

For the aero-derivative turbine (LM-5000) cases, a single train for all process sections and units was used. The "small" utility turbine (MS-6101FA) case required use of two gasification trains to provide adequate fuel gas. This also imparts some part-load redundancy in these systems. Each plant section is discussed further below.

\subsection{Wood Preparation and Drying}

Design of the wood receiving, handling, and drying operations was based on a number of existing studies in this area [4],[5],[6]. Wood chips sized to $0 \times 2$ " are delivered by truck to the plant site at a cost of $\$ 46 /$ bone dry Tonne (\$42/bone dry ton). The feed requirements for each plant are shown in Table 2. The wood was unloaded and moved to the paved storage yard that was sized to provide one week of feed storage. Wood reclaimed from the storage yard was sized to less than $1 \frac{1 / 2}{2}$ and conveyed to the wet feed storage silo (one day of storage). Wood from the silo was conveyed from the silo to the dryers ( 2 in parallel) and then to the "live" or "day" storage tank from which it is fed to the gasifier.

\begin{tabular}{|l|c|}
\hline \multicolumn{2}{|c|}{ Table 2: Biomass Feed Requirements for Each Analysis } \\
\hline & $\begin{array}{c}\text { Feed Requirements } \\
\text { (bone dry T/day) }\end{array}$ \\
\hline High pressure gasifier, aero-derivative gas turbine & 683 \\
\hline High pressure gasifier, indirect quench & 683 \\
\hline High pressure gasifier, greenfield plant & 683 \\
\hline High pressure gasifier, advanced utility gas turbine & 1467 \\
\hline Low pressure indirectly-heated gasifier, utility gas turbine & 1,486 \\
\hline Low pressure air-blown gasifier, utility gas turbine & 1,297 \\
\hline
\end{tabular}


The wood dryers are of the co-current rotary drum type. Design conditions selected for the wood drying section result in a moisture content of $11 \%$ by weight $(17 \%$ in the low-pressure direct case for reasons that will be explained later). In the direct-fired gasifier plants, the gas used for wood drying was a mixture of combustion products from a small fluidized bed combustor flue gas extracted from the HRSG. For the indirectly-heated gasifier, a mixture of ambient air and char combustor flue gas is used. For each design, sufficient ambient air is mixed with the combustion products to reduce the gas temperature to $204^{\circ} \mathrm{C}\left(400^{\circ} \mathrm{F}\right)$ prior to introduction to the dryers. While this can result in a relatively high oxygen content (16 mole \%), the temperature is believed to be sufficiently low to avoid the possibility of dryer fires. Gas leaving the dryers at a temperature of $80^{\circ} \mathrm{C}\left(175^{\circ} \mathrm{F}\right)$ enters the dryer cyclone and then a baghouse to reduce particulate emissions. The temperature level at the baghouse is, again, believed to be sufficiently low to mitigate fire danger. The dried wood exits the dryers at $68^{\circ} \mathrm{C}\left(155^{\circ} \mathrm{F}\right)$ and cools further during final transport to the feed system.

\subsection{High Pressure, Air-Blown Gasification}

The high pressure gasifier system selected for this study was a fluidized bed unit similar to that under development by the Institute of Gas Technology (IGT) and marketed under the name RENUGAS ${ }^{\circledR}$. A schematic of this gasifier integrated with the combined cycle plant is shown in Figure 2. This is a pressurized, air-blown, single stage fluidized bed gasifier. The gasifier bed material is typically an inert solid such as alumina. The bed material improves fluidization quality and increases bed depth and heat capacity, solid residence time, and carbon conversion. The IGT gasifier has been operated over a wide range of temperature, pressure, oxidant, and fuel types at the process development (PDU) scale, and is the subject of a larger scale demonstration projects in the United States (Hawaii) and Europe (Finland).

\section{Figure 2: General High Pressure BIGCC Schematic}

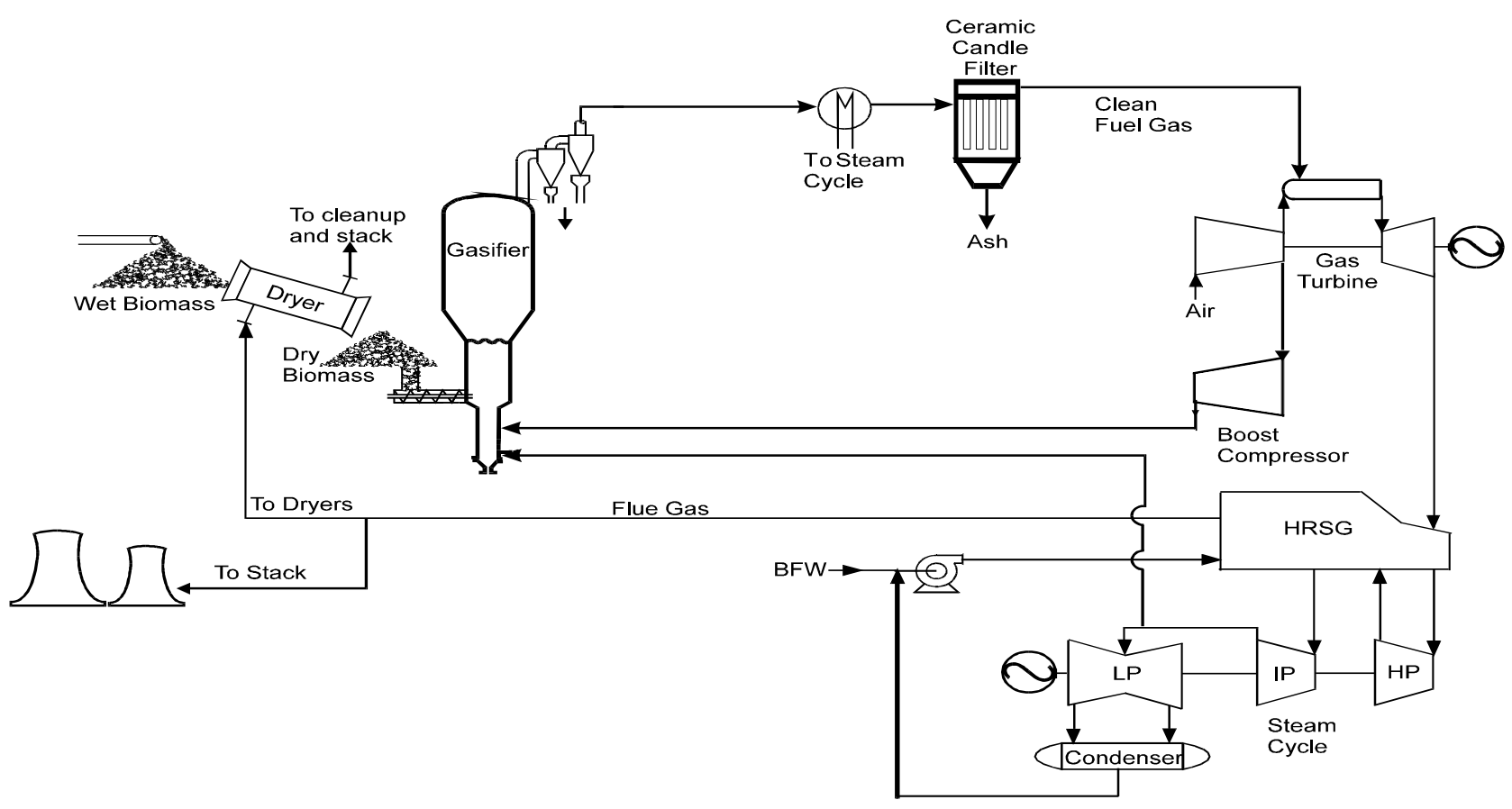


Wood from the feed lockhopper is introduced into the pressurized feed hopper with live-bottom metering screws to meter the feed into an injection screw that introduces the feed into the gasifier near the bottom of the bed. Air and a small amount of steam are introduced to effect the gasification and combustion reactions. The operating temperature selected for the gasifier for this study was 830 ${ }^{\circ} \mathrm{C}\left(1526^{\circ} \mathrm{F}\right)$. The gasifier operating pressure for aero-derivative turbine case was $3.24 \mathrm{MPa}(32 \mathrm{~atm})$ and $2.07 \mathrm{MPa}(20 \mathrm{~atm})$ for the utility gas turbine system. The former pressure is outside the currently demonstrated range for this gasifier which is $23 \mathrm{~atm}$, but is believed to be achievable due to experience with coal gasifier designs operated at similar pressures. These pressures take into account the pressure drop through the gas cleaning systems and allow for a $25 \%$ pressure drop across the gas turbine fuel control valve. Gasifier design and operating conditions are contained in Table 3. Composition of the gasifier product gas was based on experimental data from the IGT PDU gasifier tests with maple wood chips. Continued development by IGT has lead to improved gas quality and increased carbon conversion since these data were obtained. It is expected that the commercial design for this gasification technology would realize these benefits as well. The product gas composition used in this study is contained in Table 4. Product gas from the gasifier enters the primary cyclone which removes char and ash particles prior to entering the tar cracking unit.

\begin{tabular}{|l|l|}
\hline \multicolumn{2}{|l|}{ Table 3: High Pressure Gasifier Design Parameters and Operating Conditions } \\
\hline Gasifier temperature & $830^{\circ} \mathrm{C}\left(1526^{\circ} \mathrm{F}\right)$ \\
\hline Gasifier pressure & $3.17 / 2.07 \mathrm{MPa}(31.3 / 20 \mathrm{~atm})$. \\
\hline Dried wood feed to gasifier & $769 \mathrm{~T} / \mathrm{day}(843 \mathrm{t} / \mathrm{day})$ \\
\hline Dried wood moisture content & $11 \%$ \\
\hline Gasifier internal diameter & $2.86 \mathrm{~m}(9.4 \mathrm{ft})$. \\
\hline Solids throughput & $6018 \mathrm{~kg} / \mathrm{hr}-\mathrm{m}^{2}\left(1,230 \mathrm{lb} / \mathrm{hr}-\mathrm{ft}^{2}\right)$ \\
\hline Air / wood ratio (wt/wt, MAF) & 1.07 \\
\hline Steam / wood ratio (wt/wt, MAF) & 0.32 \\
\hline
\end{tabular}

Direct quenching produces a fuel gas with a lower heating value (LHV) of $4.3 \mathrm{MJ} / \mathrm{m}^{3}(115 \mathrm{Btu} / \mathrm{standard}$ cubic foot). Indirect quench produces a fuel gas of slightly higher quality $4.8 \mathrm{MJ} / \mathrm{m}^{3}(128 \mathrm{Btu} / \mathrm{standard}$ cubic foot). Analysis indicates that indirect quenching is relatively cost neutral so could be used in cases where gas quality is important. 


\begin{tabular}{|c|c|}
\hline Table 4: High Pressure Gasifier Product Gas Composition \\
\hline Component & Volume $\%$ \\
\hline $\mathrm{H}_{2}$ & 8.91 \\
\hline $\mathrm{CO}$ & 6.71 \\
\hline $\mathrm{CO}_{2}$ & 13.45 \\
\hline $\mathrm{H}_{2} \mathrm{O}$ & 39.91 \\
\hline $\mathrm{N}_{2}$ & 24.18 \\
\hline $\mathrm{CH}_{4}$ & 6.51 \\
\hline $\mathrm{C}_{2} \mathrm{H}_{4}$ & 0.01 \\
\hline $\mathrm{C}_{6} \mathrm{H}_{6}$ & 0.07 \\
\hline $\mathrm{Tars}$ & 0.16 \\
\hline $\mathrm{H}_{2} \mathrm{~S}$ & 0.005 \\
\hline $\mathrm{NH}_{3}$ & 0.06 \\
\hline $\mathrm{LHV}$ & $4.3 \mathrm{MJ} / \mathrm{m}^{3}(115 \mathrm{Btu} / \mathrm{SCF})$ \\
\hline \multicolumn{2}{|c|}{} \\
\hline
\end{tabular}

\subsection{Gasifier Design}

General gasifier size determination was based on information from the IGT 9 T/day PDU as well as the design for the scaled-up, $91 \mathrm{~T} /$ day unit operating at the Hawaiian Commercial and Sugar Company (HC\&S) sugarmill at Paia, Maui, by the Pacific International Center for High Technology Research (PICHTR). Additional demonstrations of this technology include a $64 \mathrm{~T} /$ day unit in Finland. The solid throughput, gas superficial velocity, and the ratio of bed to disengaging zone cross-sectional area were all maintained at the same level as for the $91 \mathrm{~T} /$ day demonstration unit. This yielded a gasifier vessel with a bed diameter of 2.86 meters ( 9.4 feet) between the refractory lined walls and a vessel outside diameter of 4.26 meters (14 feet).

\subsection{Gas Clean-up}

For this case, gas cleanup was accomplished by cooling the product gas to less than $538{ }^{\circ} \mathrm{C}\left(1000{ }^{\circ} \mathrm{F}\right)$ via direct quench to condense alkali species. A hot ceramic candle filter of the type being offered by Westinghouse and being demonstrated in the Clean Coal Technology Program is then used for removal of particulate matter including, it is hoped, the condensed alkali compounds. Recent tests of tar cracking and this particulate and alkali removal strategy were conducted at the IGT PDU unit in Chicago. Results from these tests indicate that a tar cracker may not be necessary in an eventual commercial system design. The tars are produced in farily small quantities, and appear to be substantially cracked prior to reaching the tar cracking vessel. The particulate filters tested at IGT also did not experience any plugging problems due to tars, and were successful in reducing the particulate matter and alkali species in the gas stream to very low levels. Long-term testing of the filters will be conducted in the coming year at the PICHTR facility. For the purposes of this study, therefore quenching followed by the ceramic candle filters was assumed to be sufficient for fuel gas cleaning. 


\subsubsection{High Temperature Gas Cooling}

Alkali species present in the fuel gas can cause corrosion and deposition if introduced into the expansion section of a gas turbine. Therefore, it was necessary to remove these species prior to combustion. These must be removed to extremely low levels, typically less than one part per million. Fortunately, most alkali components present in biomass synthesis gas have relatively high condensation temperatures. Therefore, cooling to below $538^{\circ} \mathrm{C}\left(1000^{\circ} \mathrm{F}\right)$ results in condensation of the bulk of these species, usually as fine particles that can be removed with the rest of the particulates. This cooling can be accomplished in a number of ways. The base case analyzed here performs this cooling by direct injection of water into the gas stream. While this dilutes the fuel gas stream and reduces its heating value, it was the simplest and least expensive from an equipment standpoint. An alternate case utilized indirect cooling of the fuel gas, utilizing the recovered heat in the steam cycle.

\subsubsection{High Temperature Particulate Removal}

Westinghouse has been developing high temperature ceramic barrier filters for use in advanced IGCC and pressurized fluidized bed combustor (PFBC) systems. The most promising of these so far, is the ceramic candle filter unit utilizing silicon carbide filters. A unit of this type was currently being demonstrated at the Tidd PFBC site under the Clean Coal Technology (CCT) Program. Several other demonstrations of this unit are planned under additional CCT projects including the Tampa Electric IGCC demonstration and Sierra Pacific's Pinon Pine IGCC project. This unit will allow removal of particulates to levels acceptable to a gas turbine expansion section. This unit has recently becomre available as a commercial offering with the attendant performance guarantees.

\subsection{Char Combustion}

In this system, the fluidized bed char combustor provides the energy for gasifier air/steam heating, and boiler heat for the steam cycle. Char burned in the combustor has a carbon content of approximately $87 \%$. The combustor operates at a temperature of $843^{\circ} \mathrm{C}\left(1550^{\circ} \mathrm{F}\right)$ with $20 \%$ excess air. Tubes are included in the combustor system to provide air/steam heating and to recover heat for the steam cycle. Carbon conversion in the combustor was assumed to be essentially complete. As discussed earlier, the commercial version of this gasifier is likely to have very high carbon conversion ( $>99 \%$ ). In this case, a char combustor would be unnecessary and energy for air/steam heating and wood drying would be obtained from elsewhere in the process.

\subsection{Low Pressure Indirectly Heated Gasification - The BCL Gasifier}

The low pressure indirectly-heated gasifier selected for this study was developed at Battelle Columbus Laboratory specifically for biomass gasification. A schematic of this gasifier integrated with the combined cycle is shown in Figure 3. The distinctive feature of the BCL unit was that unlike direct-fired gasifiers which use both steam and air, only steam was injected with the biomass to promote gasification. Therefore, the fuel gas has a higher heating value than that produced by direct-fired gasifiers. Without rehumidifying the fuel gas, the higher heating value of the fuel gas is $16.4 \mathrm{MJ} / \mathrm{m}^{3}$ (441 Btu/scf); if the fuel gas is rehumidified to $20 \%$ by weight, its higher heating value is $14.2 \mathrm{MJ} / \mathrm{m}^{3}$ (379 Btu/scf). The heat necessary for the endothermic gasification reactions was supplied by sand circulating between a fluidized bed char combustor and the gasification vessel. In addition to acting as the heat source, the sand was the bed material for the gasifier, designed as an entrained fluidized bed reactor. Of the total amount of sand circulating between the gasifier and char combustor, $0.5 \%$ is purged to prevent ash build-up in the system. Because this stream is nearly $100 \%$ sand, 
it is likely that its means of disposal would not be subject to the same requirements as pure ash from directlyheated gasifier systems.

This integrated gasification combined cycle plant was simulated in ASPEN/SP; a Fortran subroutine controls the simulation of the gasifier. The equations in this subroutine which control the component mass balance in the gasifier were developed from regressing the experimental data from the Battelle Columbus Laboratory 9 T/day PDU [7][8]. Because of the low pressure, wood from the dryers was fed to the gasifier using an injection screw feeder. According to the simulation, the gasifier operates at nearly atmospheric pressure $(172 \mathrm{kPa}, 25$ psi) and $825^{\circ} \mathrm{C}\left(1517^{\circ} \mathrm{F}\right)$. The design parameters and operating conditions of the indirectly heated gasifier are shown in Table 5. The product gas composition, calculated in the Fortran subroutine during the ASPEN simulation is shown in Table 6. The composition of the char is dependent upon the temperature of the gasifier, which in turn is dependent upon the heat balance between the char combustor and the gasifier. The char composition is determined, therefore, by the Fortran subroutine, and is shown in Table 7.

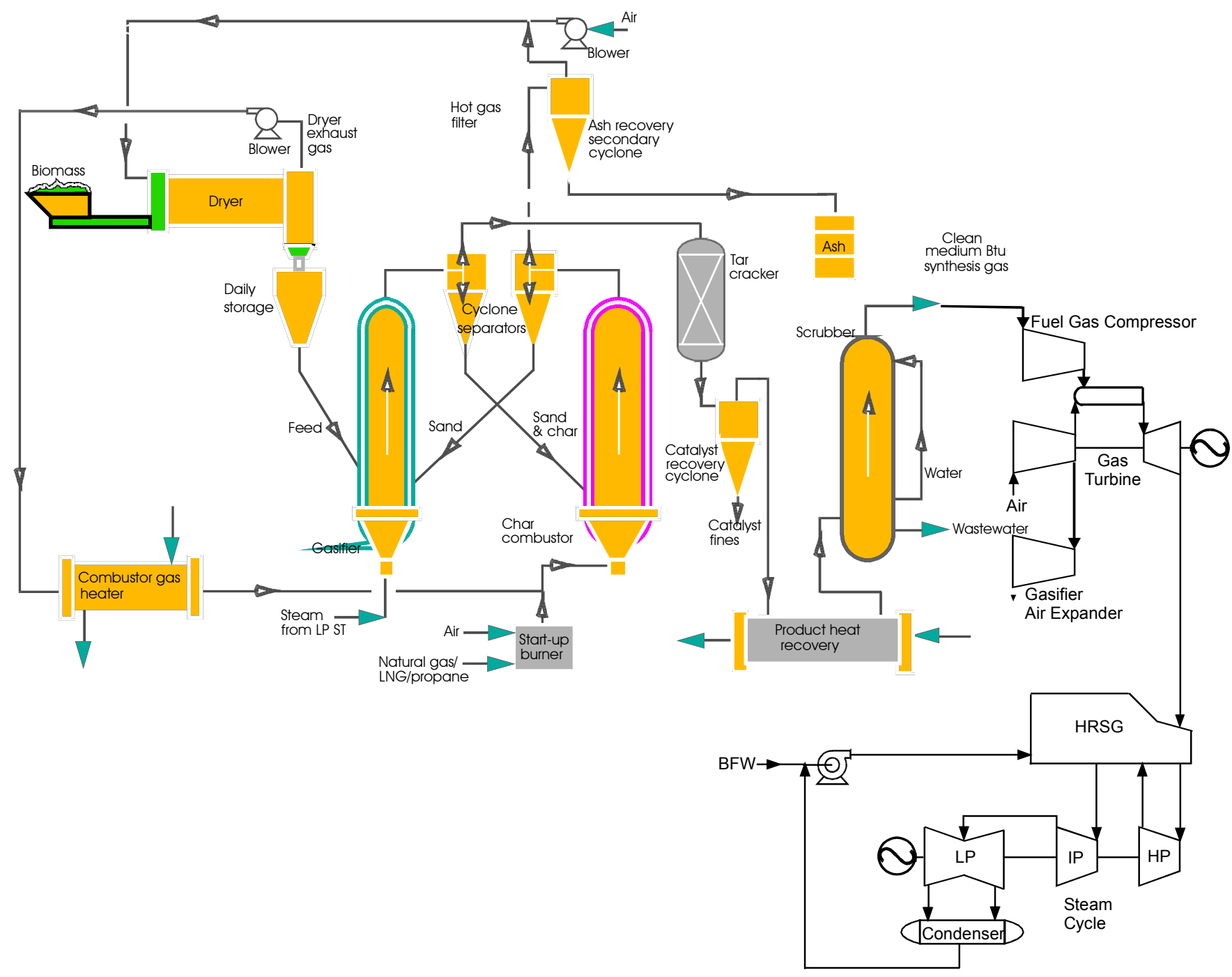

Figure 3: Low Pressure Indirect BIGCC Schematic 


\begin{tabular}{|l|l|}
\hline \multicolumn{2}{|c|}{ Table 5: Indirectly Heated Gasifier Design Parameters and Operating Conditions } \\
\hline Gasifier temperature & $826^{\circ} \mathrm{C}\left(1519^{\circ} \mathrm{F}\right)$ \\
\hline Gasifier pressure & $0.17 \mathrm{Mpa}(25 \mathrm{psi})$ \\
\hline Dried wood feed to gasifier & $1,669 \mathrm{~T} /$ day $(1,840 \mathrm{t} /$ day $)$ \\
\hline Dried wood moisture content & $11 \%$ \\
\hline Gasifier internal diameter & $2.93 \mathrm{~m}(9.6 \mathrm{ft})$ \\
\hline Steam / wood ratio (wt/wt, MAF) & 0.45 \\
\hline Sand / wood ratio into gasifier (wt/wt) & 34.4 \\
\hline
\end{tabular}

Table 6: Indirectly Heated Gasifier Product Gas Composition, dry basis

\begin{tabular}{|c|c|}
\hline Component & Volume \% \\
\hline $\mathrm{H}_{2}$ & 21.28 \\
\hline $\mathrm{CO}$ & 43.16 \\
\hline $\mathrm{CO}_{2}$ & 13.45 \\
\hline $\mathrm{CH}_{4}$ & 15.83 \\
\hline $\mathrm{C}_{2} \mathrm{H}_{2}$ & 0.36 \\
\hline $\mathrm{C}_{2} \mathrm{H}_{4}$ & 4.62 \\
\hline $\mathrm{C}_{2} \mathrm{H}_{6}$ & 0.46 \\
\hline $\mathrm{Tars}$ & 0.40 \\
\hline $\mathrm{H}_{2} \mathrm{~S}$ & 0.08 \\
\hline $\mathrm{NH}_{3}$ & 0.37 \\
\hline $\mathrm{MJ} / \mathrm{m}^{3}(354 \mathrm{Btu} / \mathrm{SCF})$ & \\
\hline & \\
\hline
\end{tabular}

Table 7: Char Composition in the Indirectly-Heated Gasifier Simulation

\begin{tabular}{|c|c|}
\hline Component & Weight \% \\
\hline Ash & 3.23 \\
\hline Carbon & 66.46 \\
\hline Hydrogen & 3.09 \\
\hline Nitrogen & 0.04 \\
\hline Sulfur & 0.03 \\
\hline Oxygen & 27.15 \\
\hline
\end{tabular}




\subsection{Drying Requirements}

To assess the feasibility of operating the low pressure indirectly-heated gasifier without a drying system, different feedstock moisture levels were tested. Results, showing the relationship between moisture content of the feed versus gasifier temperature, are shown in Figure 4. These curves represent two system designs where the air to the char combustor is fed at either ambient conditions $\left(15^{\circ} \mathrm{C}\right)$ or is preheated to $538^{\circ} \mathrm{C}$. It was found that as the moisture level increases, the heat available from the char is no longer sufficient to maintain gasification and also vaporize the water in the feed. Figure 4 shows that if the char combustion air is not preheated, a dryer is necessary. In real operation, the gasifier temperature would continue to plummet below $650{ }^{\circ} \mathrm{C}$; the curve plateaus at this point because of the lower limit set on the gasifier temperature in the ASPEN simulation. Although a dryer is still deemed necessary if the moisture content of the feed is higher than approximately $25 \%$ and the air is preheated, the drying requirements can be reduced from what is typically thought to be required (approximately $10 \%$ moisture levels) and still maintain temperatures necessary for gasification.

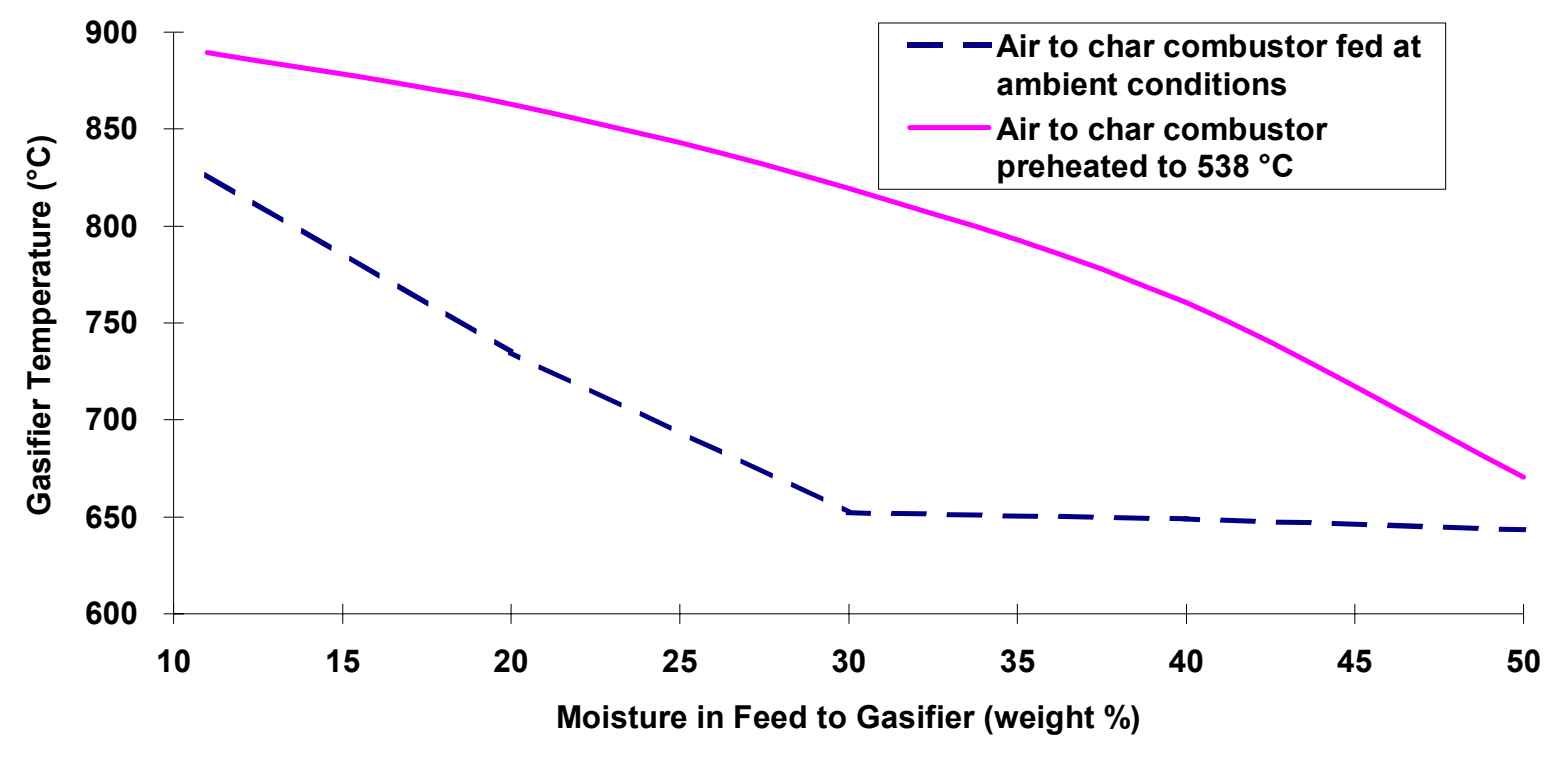

Figure 4: Gasifier Temperature as a Function of Feedstock Moisture Content

\subsection{Gas Clean-up}

Fuel gas produced by the low pressure indirectly heated gasifier was cleaned using a tar cracker to reduce the molecular weight of the larger hydrocarbons, and a cyclone separator to remove particulates. A direct water quench was used to remove alkali species and cool the gas to $97{ }^{\circ} \mathrm{C}$ for compression. As an additional safeguard, a baghouse filter was also included to remove any fine particulates that were not removed in the cyclone separator, and to ensure that any alkali species that were not removed in the quench are not fed to the compression and turbine systems. Although a tar cracker was not necessarily required since the gas was 
cooled using a direct water quench, one was included in this design to avoid losing the substantial heating value of the tars.

\subsection{Fuel Gas Compression}

Compression of the fuel gas prior to the gas turbine combustor was accomplished in a five stage centrifugal compressor with interstage cooling. This series of compressors increased the pressure from $172 \mathrm{kPa}$ to 2,068 $\mathrm{kPa}(25 \mathrm{psi}$ to $300 \mathrm{psi})$. The maximum interstage temperature was $158^{\circ} \mathrm{C}$, and the interstage coolers reduced the temperature of the syngas to $93{ }^{\circ} \mathrm{C}$. This unit operation was optimized at five stages according to the purchased equipment cost and horsepower requirements. After compression, the syngas is heated indirectly to $371{ }^{\circ} \mathrm{C}$ with process heat from the quench and char combustor flue gas.

\subsection{Rehumidification of the Syngas Prior to Combustion}

For the indirectly-heated gasifier, the efficiency, electricity output, and cost of electricity were also studied as a function of the moisture level of the syngas prior to combustion in the gas turbine combustor. During quench and compression, the water in the syngas is reduced to $7 \%$ by weight. Feeding this syngas directly to the combined cycle results in an efficiency of $35.67 \%$ and a cost of electricity of $\$ 0.0576 / \mathrm{kWh}$ on a constant dollar basis. If, however, a portion of the water that drops out of the syngas during compression is compressed and re-added such that the moisture content is $20 \%$ by weight, the efficiency and constant dollar cost of electricity are $35.40 \%$ and $\$ 0.0572 / \mathrm{kWh}$, respectively. Thus, rehumidifying the syngas prior to combustion decreases the overall efficiency of the system but increases the power output; this results in a slightly lower cost of electricity, although $2 \%$ more biomass feed is required. Increasing the moisture level of the fuel gas past $20 \%$ is not feasible as the gas turbine mass flow limit is reached and the ability of the turbine combustor to burn the wood is decreased. Naturally, the heating value of the fuel gas is reduced when water is added to it. Without rehumidifying the fuel gas, the higher heating value of the fuel gas is 16.4 $\mathrm{MJ} / \mathrm{m}^{3}$ (441 Btu/scf); at $20 \%$ by weight, its higher heating value is $14.2 \mathrm{MJ} / \mathrm{m}^{3}$ (379 Btu/scf).

\subsection{Low Pressure, Air-Blown Gasification}

The last commercially available gasifier type investigated was the low pressure direct system. The most well-known gasifier of this type is that offered by TPS and is also known as the Studsvik gasifier. The TPS gasifier has been selected for the World Bank's Global Environment Facility (GEF) project in Brazil. The GEF project will couple a TPS gasifier fueled with eucalyptus to a GE LM-2500 aero-derivative gas turbine system for power generation in northern Brazil. The TPS gasifier was also examined in a biomass IGCC application as part of a DOE/NREL sponsored site-specific feasibility study conducted by Weyerhauser [9]. Other low pressure, direct air-blown gasifiers that have been operated with biomass include the Lurgi circulating fluidized-bed gasifier and the Energy Products of Idaho (EPI) gasifier. A schematic of the system used in this study is shown in Figure 5. 


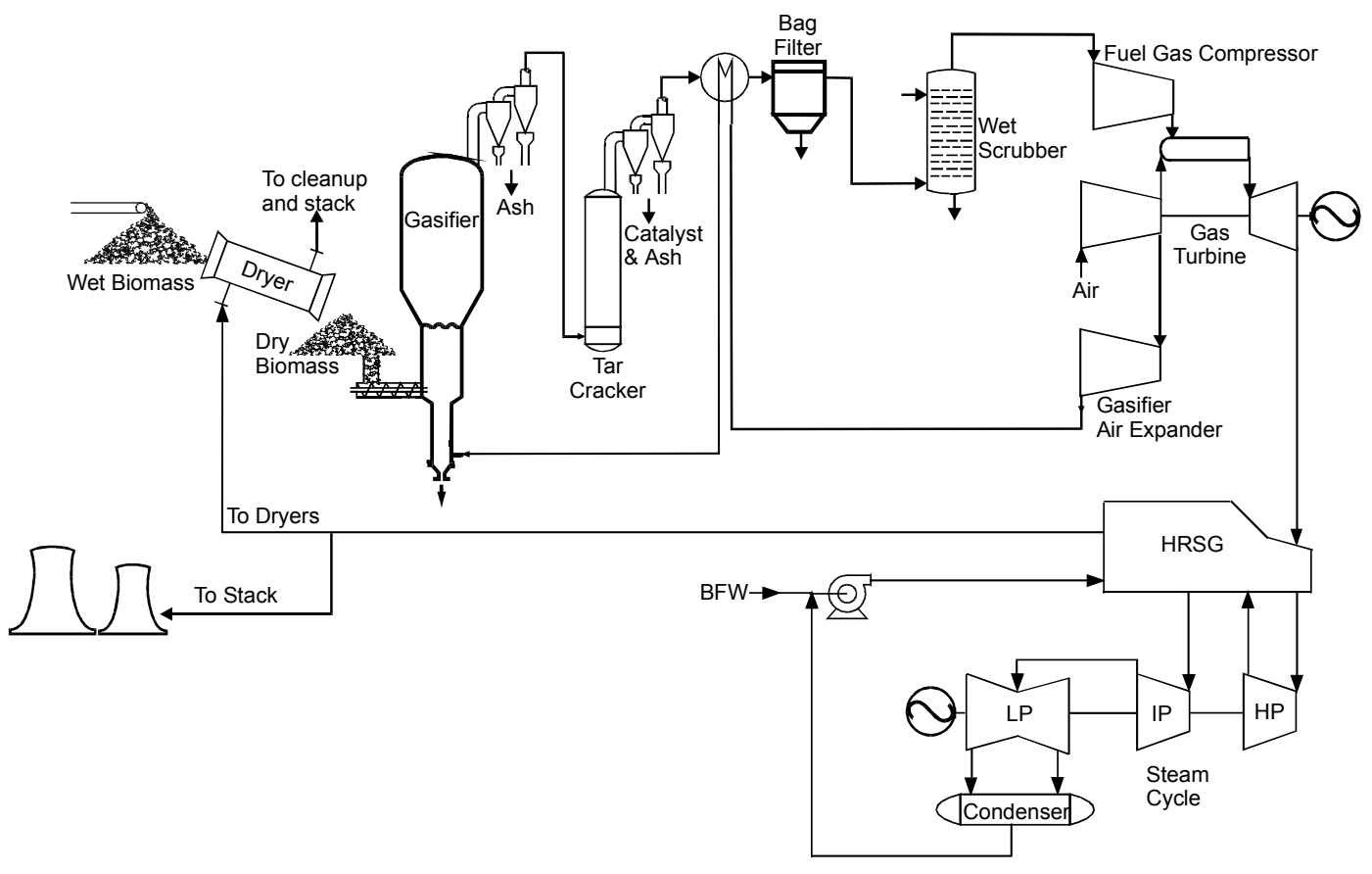

Figure 5: Low Pressure Direct BIGCC Schematic

Unfortunately, little concrete data is publicly available on the operating conditions, reactant ratios, and fuel gas produced by the TPS gasifier. For this study, therefore, data from biomass testing in a small-scale Lurgi circulating fluidized-bed gasifier [10] was used to estimate gasifier performance. The operating conditions selected for this gasifer were a temperature of $870{ }^{\circ} \mathrm{C}\left(1,600{ }^{\circ} \mathrm{F}\right)$ and a pressure of $0.14 \mathrm{MPa}(1.36 \mathrm{~atm})$. Survey of available data on gasifiers of this type indicates that steam is rarely used as part of the gasification process. It was noted that the moisture content of the dried biomass used in these gasifiers is somewhat high (up to slightly over $20 \%$ ); it is assumed that this moisture serves as the source of "steam" for the steam-carbon gasification reaction. Relatively high air/biomass ratios also seem to be common for gasifiers of this type, though again, detailed information on this point is difficult to obtain. Table 8 summarizes the operating conditions for the gasifier used in this case.

\begin{tabular}{|l|l|}
\hline \multicolumn{2}{|c|}{ Table 8: Low Pressure, Direct-Fired Gasifier Design Parameters and Operating Conditions } \\
\hline Gasifier temperature & $870^{\circ} \mathrm{C}\left(1,600^{\circ} \mathrm{F}\right)$ \\
\hline Gasifier pressure & $0.14 \mathrm{MPa}(1.36 \mathrm{~atm})$ \\
\hline Fuel gas pressure & $1.89 \mathrm{MPa}(18.6 \mathrm{~atm})$ \\
\hline Dried wood feed to gasifier & $1,460 \mathrm{~T} / \mathrm{day}(1,606 \mathrm{t} / \mathrm{day})$ \\
\hline Dried wood moisture content & $15.8 \%$ \\
\hline Air / wood ratio (wt/wt, MAF) & 2.1 \\
\hline $\begin{array}{l}\text { Steam / wood ratio } \\
(\mathrm{wt} / \mathrm{wt}, \mathrm{MAF})\end{array}$ & 0.0 \\
\hline
\end{tabular}


In order to estimate gasifier performance and fuel gas composition, a quasi-equilibrium model was used. This process employed the RGIBBS model in ASPEN/SP along with its capability to accomodate equilibrium approach temperatures for specified reactions. The problem was further complicated by the lack of information on air preheat temperature. The problem was solved by selecting the gasifier temperature and pressure and a probable air/biomass ratio. The air preheat level was adusted to yield a heat loss expected for a unit of this scale $(1.5 \%)$, and the equilibrium approach temperatures for the various gasification reactions adjusted to match reported fuel gas composition. These, of course, are not independent variables so an iterative approach was required. Nitrogen in the fuel gas provided a check on the selected air/biomass ratio. The derived fuel gas composition after the gas cleaning and conditioning described below is shown in Table 9.

\begin{tabular}{|c|c|}
\hline Table 9: Low Pressure, Direct-Fired Gasifier Product Gas Composition \\
\hline Component & Volume $\%$ \\
\hline $\mathrm{H}_{2}$ & 18.87 \\
\hline $\mathrm{CO}$ & 23.66 \\
\hline $\mathrm{CO}_{2}$ & 8.29 \\
\hline $\mathrm{H}_{2} \mathrm{O}$ & 4.85 \\
\hline $\mathrm{N}_{2}$ & 44.22 \\
\hline $\mathrm{CH}_{4}$ & 0.11 \\
\hline \multicolumn{2}{|c|}{$\mathrm{LHV}=4.8 \mathrm{MJ} / \mathrm{m}^{3}(129 \mathrm{Btu} / \mathrm{SCF})$} \\
\hline
\end{tabular}

\subsection{Gasifier Design}

Owing to the aforementioned dearth of detailed information on this gasifier, it was not possible to perform a detailed gasifier design. Instead, the design and cost information for the TPS gasifier case contained in the Weyerhauser feasibility study was scaled to fit the system examined in this report. Portions of the following system description in this section are extracted from the Weyerhauser final report, and additional details can be found therein.

Biomass is fed to the gasifier by two screw feeders that are isolated from the upstream components by pressurized rotary valves. The gasifier is a two-zone fluidized bed rector that used sand as a bed material. Biomass fed to the gasifier drops into the lower, dense phase fluidized bed. This portion of the gasifer provides sufficient residence time for gasification of the larger biomass particles. Preheated primary air enters the gasifier near the base of the vessel and maintains fluidization of this dense portion of the bed. Secondary air in added above the dense bed to produce a "fast" fluidized bed region. In this section, remaining fuel is fully pyrolized and gasified by the combined action of heat, air, and gas components.

Air for gasification is extracted from the gas turbine compressor and let down to gasifier operating pressure through a turbine. This generates an additional $8.4 \mathrm{MWe}$ of power, almost half the amount required to drive the fuel gas compressor. The air extraction rate in this case was such that the combined air and combustion product mass flow through the gas turbine expansion section and, thus the power output, was not significantly different from the design values on natural gas. 


\subsection{Gas Clean-up}

Fuel gas exiting the gasifier cyclones enters a circulating fluidized bed tar cracking unit. This unit reduces the quantity of higher hydrocarbon species in the fuel gas that could otherwise foul the fuel gas cooler, plug the fabric filters, and increase wastewater treatment loads from the gas scrubber. Dolomite is used as the bed material in the tar cracker. The higher temperature of the tar cracker $\left(920^{\circ} \mathrm{C}, 1688^{\circ} \mathrm{F}\right)$ also ensures converison of any un-gasified solids that escape the gasifier.

After exiting the second stage tar cracker cyclone, the fuel gas enters the syngas cooler. In a slight modification to the Weyerhauser report design, this unit is used to preheat gasification air as well as provide heat to the steam cycle. In actual practice, the potential safety risk of this scheme would have to be carefully evaluated though we have some assurances that such an approach is feasible[11]. In the syngas cooler, the temperature of the fuel gas is reduced to $288^{\circ} \mathrm{C}\left(550^{\circ} \mathrm{F}\right)$.

Any particulates remaining in the fuel gas are removed in a bag filter unit. As the fuel gas is cooled, volatile alkali species present in the gas stream condense on the remaining particulate matter and are removed from the system by the filter bags. The particulate-free fuel gas is cooled further in a direct contact water scrubber that removes any trace higher hydrocarbons and most of the water in the fuel gas stream. This operation also removes a significant amount of the ammonia from the fuel gas. Following this step, the gas is furhter washed with a dilute sulfuric acid stream. These combined steps remove over $95 \%$ of the ammonia from the fuel gas. This ammonia would otherwise be likely to produce $\mathrm{NO}_{\mathrm{x}}$ in the gas turbine combustor. Purge streams from both towers are sent to wastewater treatment. The fuel gas then enters a knockout drum prior to the fuel gas compressors.

\subsection{Fuel Gas Compression}

Following final fuel gas cleaning, the fuel gas is compressed for introduction into the gas turbine combusor. Although the turbine pressure ratio is only 14.9 , the fuel gas is compressed to $1.89 \mathrm{MPa}(18.6 \mathrm{~atm})$ to allow for pressure drop across the fuel control valve. This compression is accomplished in a multi-stage, intercooled centrifugal compressor. This portion of the process was not detailed in the Weyerhauser report and so was evaluated as part of the ASPEN/SPsimulation. It was noted that fewer compression/inter-cooling stages were required to maintain gas temperature within acceptable limits in this case than in the indirect gasifier case. Presumably this is due to differences in the gas composition.

\subsection{Combined Cycle Power Generation}

Since the output, performance, and conditions of the combined cycles vary across the cases examined, only the general features of the power island are discussed here. Output and efficiency data are contained later in the discussion of the results of this study. All of the equipment discussed in this section was commercially available. The MS-6101FA gas turbine will see its first commercial demonstration at Sierra Pacific's Piñon Pine IGCC plant being funded under DOE's Clean Coal Technology Program.

\subsection{Gas Turbine}

$\operatorname{Hot}\left(538^{\circ} \mathrm{C}\right.$ for the pressurized gasifier system, $371{ }^{\circ} \mathrm{C}$ for the low pressure indirectly-heated gasifier system, $225^{\circ} \mathrm{C}$ for the low pressure direct gasifier) clean fuel gas is introduced into the gas turbine combustor along 
with air from the high pressure turbine compressor. All scenarios tested, including those with direct quench produced fuel gas that was well within the projected requirements for combustion of low energy content gas in gas turbines. The use of a direct quench or humidification in some of the systems studied produces a fuel gas with higher moisture levels which helps reduce formation of nitrogen oxides in the combustor and increases the mass flow through the turbine expander and, thus, the turbine's power output. However, in all if the cases studied, the overall increase in mass flow through the turbine expander was less than $10 \%$ since the increased flow of low energy content fuel gas was partially offset by gasification air extracted from the compressor discharge.

An important technical qualification to selection of the turbines in this study is the ability to extract gasification air for the air-blown gasifiers from the compressor discharge. This extraction was necessary not only to realize the efficiency benefits of tight integration, but to maintain compressor/turbine power balance. Because of the reduced heating value of the gasifier product gas, a larger amount of this fuel gas (compared to natrual gas) was required to achieve design turbine firing temperatures. This additional fuel can increase the mass flow into the turbine section, depending on the amout of air extracted, and thus the turbine's power output. Without air extraction, this increase can cause compressor stall. In the case of the indirectly heated gasifier, air extraction is probably not necessary because the fuel gas produced is of a medium heat content. The air/biomass ratio for the low pressure direct gasifier (and thus the air extraction rate) is such that the turbine mass flow and power output is essentially unchanged from the natural gas design values.

The aero-derivative gas turbine selected for this study was the General Electric LM-5000PC. The LM-5000 has a higher pressure ratio $(24.8)$ and firing temperature (in excess of $1150^{\circ} \mathrm{C}$ ) than the utility machines selected for previous biomass IGCC studies. The smaller size turbines used in earlier studies were selected because of the smaller amounts of biomass fuel available compared to systems using coal or natural gas. Unfortunately, small scale utility turbines are generally the last to benefit from technological advances in the field. Therefore, resulting system efficiencies were correspondingly low relative to coal or gas IGCC systems. One of the goals of this study was to evaluate the effect the latest turbines had on biomass system efficiency. A combined cycle was selected rather than the steam-injected LM-5000 because of the lower water usage required for the combined cycle. This allows maximum flexibility for siting the plant, reduces feed water treating, and conserves water resources. The similarly sized and higher efficiency LM-6000 turbine was not selected for the study because of its even higher pressure ratio of 30 .

Air extraction has not yet been demonstrated with the LM-5000 gas turbine; however, an investigation of the feasibility and mechanics of this practice has been investigated by DOE's Fossil Energy program and such a scheme has been investigated with the related LM2500 turbine being used in the GEF project. General Electric and other turbine manufacturers are incorporating air extraction provisions into some utility turbine designs including the MS-6101FA discussed below. Westinghouse also commercially offers for biomass-derived as well as natural gas fuels, the 251B12 "ECONOPAC"TM" combined cycle system. This package is nominally rated at $50 \mathrm{MW}$, includes low- $\mathrm{NO}_{\mathrm{x}}$ combustion technology, and has a net efficiency of $46.5 \%$ (LHV basis) on natural gas fuel.

Within the last few years, a smaller, advanced utility gas turbine has also become available, the GE MS6101FA. This turbine moves GE's "F" technology (high firing temperature, high efficiency) down from the company's $160 \mathrm{MW}$ MS-7221FA machine to a $70 \mathrm{MW}$ class machine. This increases the Frame 6 efficiency to $34.2 \%$ (simple cycle, LHV, natural gas) from the $30 \%$ range previously typical for this scale and type of machine. The increased mass flow and temperature of the turbine exhaust also allows the use of more sophisticated steam cycles in this size range. The pressure ratio of utility machines ( 14.9 for the $6 \mathrm{FA}$ ) was 
also more compatible with demonstrated biomass gasifier operation. Further, the MS-6101FA is able to accommodate extraction of up to $20 \%$ of the compressor discharge flow to supply a gasifier [12]. A recent Gas Turbine World article [13] also discusses GE's 20\% uprate of this turbine's power output when fueled with synthesis gas. For these reasons, systems incorporating the Frame 6FA turbine were also evaluated. It was believed that the substantially increased efficiency would offset the system size increase and keep the feed requirements within what might be available from a dedicated feedstock supply system (DFSS).

\subsection{Heat Recovery Steam Generator}

Gas turbine exhaust was ducted to the heat recovery steam generator (HRSG). For the LM-5000 based cases, the HRSG design and conditions were derived from published information on the LM-5000 steam-injected turbine [14]. This was done to avoid issues of availability of high performance HRSG's for small-scale turbines and the associated cost data. The HRSG incorporates a superheater, high and low pressure boilers and economizers. Superheated steam $\left(394^{\circ} \mathrm{C}, 5.3 \mathrm{MPa}\right)$ was provided for the gasifier and the steam cycle. Medium pressure steam $(1.4 \mathrm{MPa})$ was also provided for the steam cycle. The exhaust temperature from the HRSG in all cases, $140^{\circ} \mathrm{C}\left(284^{\circ} \mathrm{F}\right)$, was sufficiently high to avoid any possible corrosion in the stack and to mitigate plume visibility issues.

Given the higher turbine exhaust temperature $\left(618^{\circ} \mathrm{C}, 1145^{\circ} \mathrm{F}\right)$, a more complicated HRSG was utilized for the systems integrated with the MS-6101FA gas turbine. In this case, the HRSG provides steam superheating and steam reheat, as well as the high and low pressure boilers and economizers. For all designs, HRSG's were designed with superheater temperature approaches of $16-33^{\circ} \mathrm{C}\left(30-60^{\circ} \mathrm{F}\right)$ and pinch points of $22^{\circ} \mathrm{C}$ $\left(40^{\circ} \mathrm{F}\right)$. Boiler blowdown was assumed to be $2 \%$, and feedwater heating and deaeration are performed in the HRSG system. All feedwater pumps are motor driven rather than steam turbine driven.

In all direct gasifier systems studied, supplemental heat for drying is provided by flue gas extraction from an appropriate point in the HRSG.

\subsection{Steam Turbine System}

The steam turbine system for the LM-5000 cases was relative simple comprising high (HP) and low pressure (LP) power turbines and a generator. Superheated steam $\left(394^{\circ} \mathrm{C}, 5.3 \mathrm{MPa}\right)$ was introduced into the high pressure turbine and expanded to $1.4 \mathrm{MPa}(200 \mathrm{psia})$. Exhaust from the HP turbine was combined with additional steam from the LP boiler and introduced to the LP turbine which exhausts to the condenser at 6,900 $\mathrm{Pa}(2$ in. $\mathrm{Hg})$.

For the MS-6101FA case, the steam cycle was somewhat more advanced. Superheated steam at $538^{\circ} \mathrm{C}$ and $10 \mathrm{MPa}\left(1000^{\circ} \mathrm{F}, 1465 \mathrm{psia}\right)$ was expanded in the HP turbine. Gasification steam, where required, was extracted from the HP exhaust. The remaining steam was combined with steam from the LP boiler, reheated, and introduced into the intermediate pressure (IP) turbine. Exhaust from the IP turbine was passed though the LP turbine and condensed at 6,900 $\mathrm{Pa}(2 \mathrm{in} . \mathrm{Hg}$ ). Expanded steam quality leaving the LP turbine in all cases was 90 per cent. Assumed generator efficiency was $98.5 \%$.

\subsection{General Facilities}

A mechanical induced-draft cooling tower was assumed for each design. This includes all of the necessary pumps for condenser cooling and makeup water needs. Balance of plant equipment includes plant water supply and demineralization facilities, firewater system, waste water treating, service and instrument air 
system, and the electric auxiliary systems. General facilities included are roads, administrative, laboratory and maintenance buildings, potable water and sanitary facilities, lighting, heating and air conditioning, flare, fire water system, startup fuel system, and all necessary computer control systems. In addition, the greenfield case included costs for land and land development, as well as an electrical substation for transmission access.

\subsection{Overall System Performance}

Process conditions and system performance for each of the cases examined are summarized in Table 10. Net system output ranges from $55.5 \mathrm{MW}_{\mathrm{e}}$ for the LM-5000 cases to $131.7 \mathrm{MW}_{\mathrm{e}}$ for the high pressure gasifier MS-6101FA case. Net system efficiency ranges from $35.4 \%$ for the low pressure indirect gasifier case to 39.7 for the high pressure gasifier MS-6101FA case. Gas turbine output and efficiency based on fuel heating value are greater than those listed in the literature for natural gas fuel. These increases are primarily the result of high fuel gas temperatures and the increased mass flow through the turbine expander (due to lower energy content fuel gas). The gas turbine power output in the high pressure gasifier case is in excess of the $20 \%$ performance augmentation claimed by GE for their turbine operated on synthesis gas fuel. The turbine may need to be de-rated in this case using more sophisticated modelling techniques.

The performance results from the simulation demonstrate a number of salient points. It was clear that use of advanced turbine technology results in significant efficiency gains. Predicted efficiency of the worst case considered was nearly eight percentage points higher than the best previous biomass IGCC system study. It is also clear that the lower gas turbine efficiency of the MS-6101F (as compared to the LM-5000) was more than compensated by the more advanced steam cycle that was possible with its increased exhaust flowrate and temperature.

\begin{tabular}{|c|c|c|c|c|}
\hline \multicolumn{5}{|c|}{ Table 10: Process Data Summary and System Performance Results } \\
\hline & $\begin{array}{l}\text { High pressure } \\
\text { gasifier, aero- } \\
\text { derivative gas turbine }\end{array}$ & $\begin{array}{l}\text { High pressure } \\
\text { gasifier, advanced } \\
\text { utility turbine }\end{array}$ & $\begin{array}{l}\text { Low-pressure indirectly- } \\
\text { heated gasifier, advanced } \\
\text { utility gas turbine }\end{array}$ & $\begin{array}{l}\text { Low pressure air-blown } \\
\text { gasifier, advanced } \\
\text { utility gas turbine }\end{array}$ \\
\hline \multicolumn{5}{|c|}{ Gasifier Requirements } \\
\hline $\begin{array}{l}\text { Bone dry wood } \\
\text { flowrate, } \\
\text { T/day (t/day) }\end{array}$ & $683(753)$ & $1,467(1,617)$ & $1,486(1,638)$ & $1,297(1,430)$ \\
\hline $\begin{array}{l}\text { Air flowrate, } \\
\mathrm{kg} / \mathrm{s}(\mathrm{lb} / \mathrm{hr})\end{array}$ & $9.2(72,674)$ & $18.1(143,178)$ & 0 & $29.7(235,469)$ \\
\hline $\begin{array}{l}\text { Steam flowrate, } \\
\mathrm{kg} / \mathrm{s}(\mathrm{lb} / \mathrm{hr})\end{array}$ & $2.5(20,044)$ & $5.4(43,181)$ & $7.7(61,346)$ & 0 \\
\hline \multicolumn{5}{|l|}{ Fuel Gas } \\
\hline $\begin{array}{l}\text { Fuel gas flowrate, } \\
\mathrm{kg} / \mathrm{s}(\mathrm{lb} / \mathrm{hr})\end{array}$ & $23.0(182,520)$ & $47.7(378,360)$ & $14.5(114,734)$ & $43.8(347,040)$ \\
\hline $\begin{array}{l}\text { Fuel gas heating } \\
\text { value, } \mathrm{LHV} \text {, wet } \\
\text { basis, } \mathrm{MJ} / \mathrm{m}^{3} \\
(\mathrm{Btu} / \mathrm{SCF})\end{array}$ & $4.3(115)$ & $4.3(115)$ & $13.2(353.9)$ & $4.8(129)$ \\
\hline
\end{tabular}




\begin{tabular}{|c|c|c|c|c|}
\hline & $\begin{array}{l}\text { High pressure } \\
\text { gasifier, aero- } \\
\text { derivative gas turbine }\end{array}$ & $\begin{array}{l}\text { High pressure } \\
\text { gasifier, advanced } \\
\text { utility turbine }\end{array}$ & $\begin{array}{l}\text { Low-pressure indirectly- } \\
\text { heated gasifier, advanced } \\
\text { utility gas turbine }\end{array}$ & $\begin{array}{l}\text { Low pressure air-blown } \\
\text { gasifier, advanced } \\
\text { utility gas turbine }\end{array}$ \\
\hline \multicolumn{5}{|l|}{ Power Island } \\
\hline Gas turbine & GE LM-5000PC & GE MS-6101FA & GE MS-6101FA & GE MS-6101FA \\
\hline Turbine PR & 24.8 & 14.9 & 14.9 & 14.9 \\
\hline $\begin{array}{l}\text { Turbine firing } \\
\text { temperature, } \\
{ }^{\circ} \mathrm{C}\left({ }^{\circ} \mathrm{F}\right)\end{array}$ & $\begin{array}{l}1,154(2,110) \\
\text { estimated }\end{array}$ & $\begin{array}{l}1,288(2,350) \\
\text { estimated }\end{array}$ & $1,288(2,350)$ & $1,288(2,350)$ \\
\hline $\begin{array}{l}\text { Steam cycle } \\
\text { conditions, } \\
\mathrm{MPa} /{ }^{\circ} \mathrm{C} /{ }^{\circ} \mathrm{C} \mid \\
\left(\mathrm{psia} /{ }^{\circ} \mathrm{F} /{ }^{\circ} \mathrm{F}\right)\end{array}$ & $5.3 / 395(770 / 742)$ & $\begin{array}{l}10 / 538 / 538 \\
(1,465 / 1,000 / 1,000)\end{array}$ & $\begin{array}{l}10 / 538 / 538(1,465 / 1,000 / \\
1,000)\end{array}$ & $\begin{array}{l}10 / 538 / 538 \\
(1,465 / 1,000 / \\
1,000)\end{array}$ \\
\hline \multicolumn{5}{|c|}{ Power Production Summary } \\
\hline $\begin{array}{l}\text { Gas turbine } \\
\text { output, } \mathrm{MW}_{\mathrm{e}}\end{array}$ & 50.3 & 93.1 & 82.1 & 72.9 \\
\hline $\begin{array}{l}\text { Steam turbine } \\
\text { output, } \mathrm{MW}_{\mathrm{e}}\end{array}$ & 8.95 & 46.6 & 55.1 & 47.6 \\
\hline $\begin{array}{l}\text { Internal } \\
\text { consumption, } \\
\mathrm{MW}_{\mathrm{e}}\end{array}$ & 3.79 & 8.02 & 15.2 & 15.1 \\
\hline $\begin{array}{l}\text { Net system } \\
\text { output, } \mathrm{Mw}_{\mathrm{e}}\end{array}$ & 55.5 & 131.7 & 122 & 105.4 \\
\hline $\begin{array}{l}\text { Net plant } \\
\text { efficiency, \%, } \\
\text { HHV basis }\end{array}$ & 36.0 & 39.7 & 35.4 & 37.9 \\
\hline
\end{tabular}

\subsection{Economic Analysis}

The selling price of electricity in 1990 (the base year for this report) was $\$ 0.047 / \mathrm{kWh}, \$ 0.073 / \mathrm{kWh}$, and $\$ 0.078 / \mathrm{kWh}$ for industrial, commercial, and residential customers, respectively (EIA, Annual Energy Review, 1993). By calculating the economics of the processes being studied and comparing the results to the prices within the electricity generating market, the potential profitability can be assessed.

\subsection{Economic Analysis Methodology}

The levelized cost of electricity from three BIGCC systems was calculated by setting the net present value of the investment to zero. The method and assumptions that were used are based on those described in the EPRI Technical Assessment Guide (TAG) [15] and reflect typical utility financing parameters. Independent power producers or cogenerators would clearly have different analysis criteria. The spreadsheet used for COE calculations was developed at DOE's Morgantown Energy Technology Center. A summary of the economic assumptions is presented in Table 11. 


\section{Table 11: Economic Assumptions}

\begin{tabular}{|c|c|c|c|c|c|}
\hline \multicolumn{6}{|c|}{ December, 1990 dollars } \\
\hline \multicolumn{6}{|c|}{30 year project life } \\
\hline \multicolumn{6}{|l|}{30 year book life } \\
\hline \multicolumn{6}{|l|}{20 year tax life } \\
\hline \multicolumn{6}{|c|}{ General plant facilities $=10 \%$ of process plant cost } \\
\hline \multicolumn{6}{|c|}{ Project contingency $=15 \%$ of plant cost } \\
\hline \multicolumn{6}{|c|}{ Two year construction period } \\
\hline \multicolumn{6}{|c|}{ Royalties $=0.5 \%$ of process plant cost } \\
\hline \multicolumn{6}{|c|}{ Feedstock cost $=\$ 46 / \mathrm{T}(\$ 42 / \mathrm{t})$} \\
\hline \multicolumn{6}{|c|}{ Sixty days supply of fuel and consumable materials } \\
\hline \multicolumn{6}{|c|}{ Accelerated Cost Recovery System (ACRS) depreciation } \\
\hline \multicolumn{6}{|c|}{ Federal and state income tax rate $=41 \%$} \\
\hline \multicolumn{6}{|c|}{ Yearly inflation rate for calculation of current dollar cost $=4 \%$} \\
\hline \multicolumn{6}{|c|}{ Zero investment tax credit } \\
\hline \multicolumn{2}{|c|}{ Financial Structure } & \multicolumn{2}{|c|}{ Current Dollar } & \multicolumn{2}{|c|}{ Constant Dollar } \\
\hline $\begin{array}{l}\text { Type of } \\
\text { Security }\end{array}$ & $\%$ of Total & Cost, $\%$ & Return, \% & Cost, $\%$ & Return, $\%$ \\
\hline Debt & 50 & 8.6 & 4.3 & 4.5 & 2.3 \\
\hline Preferred Stock & 8 & 8.3 & 0.7 & 4.2 & 0.3 \\
\hline Common Stock & 42 & 14.6 & 6.1 & 10.3 & 4.3 \\
\hline Discount Rate (c & st of capital) & & 11.1 & & 6.9 \\
\hline
\end{tabular}

\subsection{Capital Cost Estimates}

Capital costs for the systems were estimated using a combination of capacity factored and equipment-based estimates. Capacity factored estimates utilize the ratio of the capacity (flowrate, heat duty, etc.) of an existing piece of equipment to the new equipment multiplied by the cost of the existing equipment to estimate the cost of the new equipment. A scale-up factor particular to the equipment type was applied to the capacity ratio. The equipment-based estimates were determined from more detailed equipment design calculations based on the process conditions and results of the simulations. All costs were estimated in instantaneous 1990 dollars. Where necessary, costs were corrected to 1990 using the M\&S or Chemical Engineering equipment cost indices. A charge of $20 \%$ of the installed cost of the major plant sections was 
taken to account for all balance of plant (BOP) equipment and facilities. Additional costs a for substation and land were included for the greenfield case.

The major equipment costs were multiplied by a factor to arrive at the total direct cost of the installed equipment. Table 12 lists the factors used to determine total direct cost. In the design of the various pieces of process equipment, every effort was made to specify units that were modular and capable of being shop fabricated and shipped by rail. It was believed that this approach will help keep capital costs low and shorten the learning curve in deployment of plants of this type.

\begin{tabular}{|l|l|}
\hline \multicolumn{2}{|c|}{ Table 12: Cost Factors Used for Calculation of Total Direct Cost } \\
\hline Installation & $15 \%$ of delivered equipment cost \\
\hline Piping & $45 \%$ of delivered equipment cost \\
\hline Instrumentation & $10 \%$ of delivered equipment cost \\
\hline Buildings and Structures & $10 \%$ of delivered equipment cost \\
\hline Auxiliaries & $25 \%$ of delivered equipment cost \\
\hline Outside Lines & $10 \%$ of delivered equipment cost \\
\hline Total Direct Plant Cost (TDC) & $\mathbf{2 1 5 \%}$ of delivered equipment cost \\
\hline
\end{tabular}

\subsubsection{Wood Preparation and Drying Costs}

The majority of the equipment necessary for solids handling, storage, sizing, and conveying was scaled from a study performed by Tecogen for a similar sized IGCC plant based on the BCL indirectly heated gasifier [16]. A magnetic separator was added as one was not explicitly included in the Tecogen analysis. Costs for the separator were determined from a detailed study on wood handling equipment [17]. The dryers were sized based on the methodology outline in the Tecogen study and the costs were developed from Perry's Chemical Engineers' Handbook [18]. A baghouse was added to remove wood particles from the dryer exit. Costs for the baghouse were developed used the CHEMCOST program. The equipment included in the wood preparation and drying section includes the following: truck unloaders and truck scales, chip yard handling equipment, one week storage paved chip yard, one day storage silo, sizing bin/chip hogger, conveyor/bucket elevator, magnetic separator, rotary drum dryers, and baghouse filter.

\subsubsection{Gasification Costs}

The costs of the high pressure air-blown gasifier and its associated equipment were initially based on work done for EPRI by Southern Company Services [19]. Because of the similarities in design and operating conditions, the cost for the gasifier and its associated equipment was based on that for the Kellogg-RustWestinghouse (KRW) coal gasifier. While this report was being revised and finalized, however, more recent and applicable cost data became available. In May of 1995, Northern States Power (NSP) completed a report on a site-specific feasibility study that evaluated biomass gasification combined cycle technology for rural power generation [20]. This report included cost estimates for the Tampella Power Systems (not associated in any way with TPS) biomass gasifier. Tampella are a licensee of the IGT gasifier technology and it is believed that their design and costs are representative of the high-pressure gasifier used in this study. 
Therefore, the gasification section cost contained in the NSP report was scaled and modified to reflect a projected $\mathrm{n}^{\text {th }}$ plant cost and used in the final version of the cost figures for systems incorporating the high pressure direct gasifier. These revised, higher, costs also reflect the consensus position on the cost of $\mathrm{n}^{\text {th }}$ plant biomass IGCC systems developed in discussions with EPRI, Princeton, Colorado School of Mines, and others and documented in an EPRI paper [21]. The original cost figures can be found in an ASME paper by the authors [22]. For the utility turbine case, two gasification trains of equal size were used to provide the required quantity of fuel gas to the turbine. The boost compressor for the gasification air was sized based on the ASPEN/SP simulation and its cost determined from a standard references [23],[24],[25],[26].

The costs associated with the low pressure indirectly heated gasifier were determined by studying and evaluating the accuracy of costs developed by several independent sources[27],[28],[29],[30]. It was assumed that two gasification trains of equal capacity will be needed. Equipment included in the gasification section include the gasifier, char combustor, char combustor cyclone, sand surge pots, ash cyclone, sand makeup hopper, startup burner and blower, and steam supply valves.

The costs of the low pressure air-blown gasifier were developed from information contained in the Weyerhauser feasibility study [31] for the TPS gasification system. The capital costs are reported by overall plant section (e.g. "Gasification", "Power Block") so detailed analysis and scaling was not possible for each piece of eqiupment. Given that the gasification system design was essentially identical to that used in our simulation, the entire gasification section cost was scaled to the size required for use with an MS-6101FA gas turbine using an overall scale factor of 0.8 . This assumes, of course, that a single train could be increased in scale by $60 \%$. Otherwise, two parallel trains would be required. This would increase the gasification section capital cost by approximately $15 \%$.

\subsubsection{Gas Clean-up Costs}

\section{Tar cracker}

The initial tar cracker design was developed using laboratory data [32] including space velocities of 2000 $\mathrm{hr}^{-1}$; however, this resulted in extremely large and shallow beds. Further examination of the laboratory data revealed that very large space velocities were utilized to quickly test catalyst life. Therefore, a reduced space velocity ( $35 \%$ of the lab value) was adopted for the design. This resulted in reasonable superficial gas velocities and a vessel size of 4.26 x 12.8 meters ( $14 \times 42 \mathrm{ft}$.). The module cost for the tar cracker was determined using the CHEMCOST program and the cost factor applied.

\section{High temperature gas cooling}

For the cases that used a direct quench, the cost of a quench pump was determined with the CHEMCOST program. For the indirect gas cooling case, the area and size of the heat exchanger required was calculated utilizing standard methods [33] and based on data from the system simulation. The cost of this indirect cooler was determined from the CHEMCOST program. In both cases, a cost factor of 0.7 was applied to the basic equipment cost.

\section{High temperature particulate removal}

Based on information supplied by the equipment vendor [34], it was believed that a hot gas filtration unit similar in size to that being demonstrated with the Tidd pressurized fluidized bed combustor (PFBC) system under the Clean Coal Program would be appropriate for a gasification train of the size being evaluated in this report. The vendor supplied an FOB cost for the hot gas filtration unit. The installation factor applied to the 
particulate filter was reduced slightly given the highly modular, shop fabricated nature of the unit. This cost was further confirmed against data contained in the NSP report which used a similar system.

\subsubsection{Compression Costs for Low Pressure Gasifier Systems}

In the low pressure indirectly heated gasifier plant, a five stage compression system with interstage cooling was used to boost the pressure of the syngas prior to combustion in the gas turbine combustor. The purchase price and total power requirement for this compression operation were estimated to be $\$ 3.8 \mathrm{MM}$ and 9.6 $\mathrm{MW}_{\mathrm{e}}$, respectively. This unit was optimized at five stages according to the purchased cost and horsepower requirements which were higher for both four stage $\left(\$ 4.1 \mathrm{MM}, 9.7 \mathrm{MW}_{\mathrm{e}}\right)$ and six stage $\left(\$ 3.9 \mathrm{MM}, 9.7 \mathrm{Mw}_{\mathrm{e}}\right)$ compression systems.

The cost for the fuel gas compressor is included in the gasification section system cost from the Weyerhauser report that was used to develop an overall cost for the gasification system up to the combined cycle system. Therefore, cost details for the compressor itself are not available. Data from the ASPEN simulation indicates that two or three compressor stages with inter-cooling would be required to raise the fuel gas to the necessary pressure. The number of stages is largely constrained by the allowable outlet temperature of each stage and the thermodynamic characteristics of the fuel gas.

\subsubsection{Char Combustor Cost for High Pressure Gasifier System}

The base cost for the char combustor for the direct gasification systems was determined from the ENFOR reports [35] on commercially available equipment for wood combustion and the result independently confirmed [36]. The size was determined based on the heat duty of the unit. The total cost for the combustor system was reduced by $30 \%$ from that found in the ENFOR reports, since a substantial fraction of the heat recovery in the commercial system (and therefore a substantial fraction of the heat exchange area) was not needed for this application. The system cost included the feed system, primary air, boil, and ash removal system. The final cost for the wood handling and drying section was compared with an independent cost estimate for a system of similar size[37], and found to be similar.

As discussed earlier, if gasifier carbon conversion achieves high levels in the final commercial, this plant section will not be required. This would result in a total capital requirement savings of $\$ 2.1$ million in the aero-derviative turbine case and $\$ 3.3$ million in the utility gas turbine case as well as an indeterminate amount of O\&M expense.

\subsubsection{Combined Cycle Power Generation Costs}

\section{Gas Turbine}

Costs for the gas turbines utilized in this study were determined from published data [38] or from the manufacturer. Again, installation factors were slightly reduced because of the modular nature of the gas turbines and associated equipment.

\section{Heat Recovery Steam Generator}

The cost of the HRSG for the LM-5000 turbine was estimated from published sources [39], [40]. The HRSG cost for the MS-6101FA turbine was scaled from the cost for a similar unit for the MS-7001FA turbine [41]. 


\section{Steam Turbine System}

The cost for the steam cycles for both systems were determined from capacity costs $(\$ / \mathrm{kW})$ from a number of sources [42], [43], [44]. The estimated cost included all ancillary equipment for the cycle including mechanical draft cooling tower, feedwater pumps, condenser, etc, and was estimated to be $\$ 250 / \mathrm{kW}$ of the steam turbine output for the large steam cycles and $\$ 350 / \mathrm{kW}$ for the smaller steam cycles.

\subsection{Total Plant Cost, Total Plant Investment, and Total Capital Requirements}

To obtain the total plant cost (TPC), capital costs were added to the installed equipment cost for general plant facilities ( $10 \%$ of process plant cost), engineering fees ( $15 \%)$, and project contingency ( $15 \%$ of process plant cost + general plant facilities cost). The percentages were selected from ranges provided in EPRI TAG [45]. No process contingencies were applied to the individual plant sections as this was assumed to be a mature plant.

The total plant investment (TPI) was determined by adding the interest cost plus inflation to the TPC. The period of construction was assumed to be 2 years and construction interest was assumed to be $4.5 \%$.

The total capital requirement (TCR) for the plant was the sum of the TPC, TPI, royalties, startup costs, initial catalyst and chemicals, working capital, spare parts, and land (where applicable). A summary of the capital costs for each case was contained in Table 13. Capital cost details for all cases are contained in Appendices A1-A6.

\subsection{Operation and Maintenance Costs}

Operating and maintenance costs for the plant were based on an $80 \%$ capacity factor. Wood costs were assumed to be $\$ 46 / \mathrm{Mg}$ ( $\$ 42$ per bone dry ton). It was assumed that 2 operators per shift were required for the LM-5000 based systems, and 5 operators per shift for the MS-6101FA based system. This number of operators is substantially reduced over the EPRI TAG numbers and those contained in our earlier evaluation. This revised estimate is a result of developing operating trends and the consensus position arrived at between NREL, EPRI, Princeton, and others. A summary of annual operating costs for each case is contained in Table 14. Ash disposal costs for the indirectly-heated gasifier case are significantly higher than in the other cases because a large amount of sand was purged to prevent build-up of ash in the system. It is likely that this sand stream will not be disposed of in the same manner as pure ash streams from the other gasifiers, but a more conservative approach was taken in assuming the cost per tonne was the same. 


\begin{tabular}{|c|c|c|c|c|c|}
\hline \multicolumn{6}{|c|}{ Table 13: Capital Costs } \\
\hline & \multicolumn{5}{|c|}{ Installed Equipment Cost, \$K (1990) } \\
\hline $\begin{array}{l}\text { Plant Section } \\
\text { Description }\end{array}$ & $\begin{array}{l}\text { High } \mathrm{P} \text {, aero-deriv } \\
\text { gas turbine }\end{array}$ & $\begin{array}{c}\text { High P, greenfield } \\
\text { plant }\end{array}$ & $\begin{array}{l}\text { High } P \text {, utility } \\
\text { gas turbine }\end{array}$ & $\begin{array}{l}\text { Low } \mathrm{P} \text {, indirect, } \\
\text { utility gas turbine }\end{array}$ & $\begin{array}{l}\text { Low P, direct, } \\
\text { utility gas turbine }\end{array}$ \\
\hline Wood Handling & 2,173 & 2,173 & 4,346 & 4,400 & 3,478 \\
\hline Wood Drying & 2,724 & 2,724 & 5,448 & 5,448 & 4,360 \\
\hline Gasification & 20,972 & 20,972 & 44,475 & 14,185 & I \\
\hline Gas Cleanup & 2,700 & 2,700 & 5,400 & 5,400 & $\begin{array}{l}1 \\
1\end{array}$ \\
\hline Tar Cracker & & & & 454 & I \\
\hline Direct Quench & 15 & 15 & 30 & 30 & 33,481 \\
\hline Gas Turbine & 13,161 & 13,161 & 17,220 & 17,850 & 17,220 \\
\hline HRSG & 2,208 & 2,208 & 8,000 & 7,686 & 8,000 \\
\hline Steam Cycle & 3,133 & 3,133 & 11,675 & 12,668 & 11,900 \\
\hline $\begin{array}{l}\text { Boost } \\
\text { Compressor }\end{array}$ & 590 & 590 & 1,180 & 5,691 & $\begin{array}{l}\text { included with } \\
\text { gasification }\end{array}$ \\
\hline $\begin{array}{l}\text { Char Combustor } \\
\text { System }\end{array}$ & 1,215 & 1,215 & 2,282 & $\begin{array}{l}\text { included with } \\
\text { gasification costs }\end{array}$ & $\begin{array}{l}\text { included with } \\
\text { gasification }\end{array}$ \\
\hline Balance of Plant & 9,778 & 9,778 & 20,011 & 14,762 & 15,688 \\
\hline Substation & 0 & 3,958 & 0 & 0 & 0 \\
\hline $\begin{array}{r}\text { Subtotal, } \\
\text { Process Plant } \\
\text { Cost } \\
\end{array}$ & 58,669 & 62,627 & 120,067 & 88,575 & 94,127 \\
\hline $\begin{array}{r}\text { General Plant } \\
\text { Facilities } \\
\end{array}$ & 5,867 & 6,263 & 12,007 & 8,657 & 9,413 \\
\hline $\begin{array}{r}\text { Engineering } \\
\text { Fees } \\
\end{array}$ & & 9,394 & 18,010 & 13,286 & 14,119 \\
\hline $\begin{array}{r}\text { Project } \\
\text { Contingency } \\
\end{array}$ & 9,680 & 10,333 & 19,811 & 14,615 & 15,531 \\
\hline $\begin{array}{r}\text { Total Plant Cost } \\
\text { (TPC) }\end{array}$ & 83,017 & 88,617 & 169,895 & 125,333 & 133,189 \\
\hline $\begin{array}{r}\text { Adjustment for } \\
\text { Interest and } \\
\text { Inflation } \\
\end{array}$ & 200 & 213 & 408 & 301 & 320 \\
\hline $\begin{array}{r}\text { Total Plant } \\
\text { Investment } \\
(\mathrm{TPI}) \\
\end{array}$ & 83,216 & 88,831 & 170,303 & 129,635 & 133,510 \\
\hline $\begin{array}{r}\text { Prepaid } \\
\text { Royalties } \\
\end{array}$ & 293 & 313 & 600 & 443 & 471 \\
\hline
\end{tabular}




\begin{tabular}{|r|l|l|l|l|l|}
\hline $\begin{array}{l}\text { Plant Section } \\
\text { Description }\end{array}$ & $\begin{array}{l}\text { High P, aero-deriv } \\
\text { gas turbine }\end{array}$ & $\begin{array}{c}\text { High P, greenfield } \\
\text { plant }\end{array}$ & $\begin{array}{l}\text { High P, utility } \\
\text { gas turbine }\end{array}$ & $\begin{array}{l}\text { Low P, indirect, } \\
\text { utility gas turbine }\end{array}$ & $\begin{array}{c}\text { Low P, direct, } \\
\text { utility gas turbine }\end{array}$ \\
\hline Startup Costs & 2,250 & 2,382 & 4,649 & 4,081 & 3,683 \\
\hline Spare Parts & 415 & 443 & 849 & 627 & 666 \\
\hline $\begin{array}{r}\text { Working } \\
\text { Capital }\end{array}$ & 1,978 & 1,982 & 4,251 & 4,425 & 4,480 \\
\hline Land & 0 & 1,000 & 0 & 0 & 0 \\
\hline $\begin{array}{r}\text { Total Capital } \\
\text { Requirement } \\
(\mathrm{TCR})\end{array}$ & 88,112 & 94,951 & 180,653 & 135,211 & 141,810 \\
\hline $\begin{array}{r}\text { TCR } \\
(\$ \mathrm{~kW})\end{array}$ & 1,588 & 1,696 & 1,371 & 1,108 & 1,350 \\
\hline
\end{tabular}

\begin{tabular}{|c|c|c|c|c|c|}
\hline \multicolumn{6}{|c|}{ Table 14: Annual Operating Costs, \$K } \\
\hline & $\begin{array}{l}\text { High P gasifier, } \\
\text { aero- deriv. gas } \\
\text { turbine }\end{array}$ & $\begin{array}{l}\text { High P } \\
\text { gasifier, } \\
\text { greenfield } \\
\text { plant }\end{array}$ & $\begin{array}{l}\text { High P gasifier, } \\
\text { advanced utility } \\
\text { gas turbine }\end{array}$ & $\begin{array}{l}\text { Low P indirectly- } \\
\text { heated gasifier, } \\
\text { utility gas turbine }\end{array}$ & $\begin{array}{l}\text { Low-pressure air- } \\
\text { blown gasifier, } \\
\text { utility gas turbine }\end{array}$ \\
\hline $\begin{array}{l}\text { Wood (dry), } \\
\$ 42 / \mathrm{T}\end{array}$ & 9,198 & 9,198 & 19,794 & 20,087 & 16,250 \\
\hline Water, $\$ 0.60 / \mathrm{T}$ & 49 & 49 & 105 & 211 & 53 \\
\hline $\begin{array}{l}\text { Ash Disposal } \\
\text { Cost, } \$ 8.00 / T\end{array}$ & 9 & 9 & 19 & 822 & 16 \\
\hline $\begin{array}{l}\text { Operating } \\
\text { Labor (incl. } \\
\text { Benefits) } \\
\end{array}$ & 356 & 356 & 891 & 2,139 & 891 \\
\hline $\begin{array}{l}\text { Supervision and } \\
\text { Clerical }\end{array}$ & 306 & 320 & 675 & 1,243 & 587 \\
\hline $\begin{array}{l}\text { Maintenance } \\
\text { Costs }\end{array}$ & 1,660 & 1,772 & 3,398 & 5,013 & 2,664 \\
\hline $\begin{array}{l}\text { Insurance and } \\
\text { Local Taxes }\end{array}$ & 1,660 & 1,772 & 3,398 & 2,507 & 2,664 \\
\hline Royalties & 92 & 92 & 198 & 201 & 162 \\
\hline $\begin{array}{l}\text { Other Operating } \\
\text { Costs }\end{array}$ & 102 & 107 & 225 & 414 & 196 \\
\hline $\begin{array}{l}\text { Net Operating } \\
\text { Costs }\end{array}$ & 13,433 & 13,675 & 28,702 & 32,638 & 23,442 \\
\hline
\end{tabular}




\subsection{Cost of Electricity}

Based on the above cost information and the economic assumptions listed in Tables 11 and 12, the levelized costs of electricity (COE) were calculated for each case. The method utilized was based on that described in EPRI TAG [46]. The resulting electricity costs are summarized along with other pertinent cost data in Table 15.

\begin{tabular}{|l|l|l|l|l|l|}
\hline \multicolumn{7}{|c|}{ Table 15: Cost and Economic Summary for NREL Cases } \\
\hline & $\begin{array}{l}\text { High pressure } \\
\text { gasifier, } \\
\text { aero-deriv. gas } \\
\text { turbine }\end{array}$ & $\begin{array}{c}\text { High pressure } \\
\text { gasifier, } \\
\text { greenfield } \\
\text { plant }\end{array}$ & $\begin{array}{l}\text { High pressure } \\
\text { gasifier, advanced } \\
\text { utility } \\
\text { gas turbine }\end{array}$ & $\begin{array}{c}\text { Low-pressure } \\
\text { indirectly-heated } \\
\text { gasifier, utility } \\
\text { gas turbine }\end{array}$ & $\begin{array}{c}\text { Low-pressure air- } \\
\text { blown gasifier, } \\
\text { utility gas } \\
\text { turbine }\end{array}$ \\
\hline $\begin{array}{l}\text { Output } \\
(\text { Mw })\end{array}$ & 56 & 56 & 132 & 122 & 105 \\
\hline $\begin{array}{l}\text { Efficiency } \\
(\%, \mathrm{HHV})\end{array}$ & 36.01 & 36.01 & 39.70 & 35.40 & 37.9 \\
\hline $\begin{array}{l}\text { Capital Cost } \\
(\mathrm{TCR}, \$ / \mathrm{kW})\end{array}$ & 1,588 & 1,696 & 1,371 & 1,108 & 1,350 \\
\hline $\begin{array}{l}\text { Operating } \\
\text { Cost } \\
\text { incl. fuel } \\
(\$ 1,000 / \mathrm{yr})\end{array}$ & 13,433 & 13,675 & 28,703 & 27,983 & 23,442 \\
\hline $\begin{array}{l}\text { COE } \\
(ф / \mathrm{kW}, \\
\text { Current } \$)\end{array}$ & 7.91 & 8.2 & 6.99 & 6.55 & 7.03 \\
\hline $\begin{array}{l}\text { COE } \\
(\text { Constant } \$)\end{array}$ & 6.1 & 6.31 & 5.39 & 5.11 & 5.43 \\
\hline
\end{tabular}

\subsection{Comparison with Previous Studies}

Cost results from this study were compared with those from other investigations. Figure 6 depicts COE results from a number of biomass-to-electricity studies that utilized various technologies. The curve in this figure was represents a 0.7 scale-factor curve drawn through the COE for the high pressure gasifier base case in this report. Figure 7 correlates the capital cost results from a number of studies and cost estimate efforts. The lines on this figure represent 0.8 scale factor curves using, as a base point, the "high" and "low" technology estimates from a recent EPA study [47]. Plotted as points around the curves are the cost estimates from the various studies shown. The "GEF" study is the Global Environment Fund facility in Brazil that is using TPS gasification technology and a General Electric aero-derivative turbine [48]. The other studies are listed in the reference section [49] [50][51]. As these figures show, most of the illustrated results are reasonably consistent. The 
notable exceptions are the EPRI [52] and Ebasco[53] studies. These differences are likely due to a number of factors.

To investigate the reasons for reported differences among studies, we performed a detailed comparison of three previous biomass IGCC studies (EPRI, Tecogen, Ebasco (for EPRI and TVA), and the high pressure direct gasifier/aero-derivative turbine case in the current NREL study. Detailed cost information was not available for all studies; however, a great deal of insight was gained as a result of this analysis. Table 16 presents a brief summary of this comparison. Since we decided to compare systems of similar electricity output, the utility gas turbine cases from this study are not included in the comparison. The detailed table is included as Appendix B. The constant-dollar cost of electricity resulting from these four studies ranges from $3.3 \phi / \mathrm{kWh}$ (Ebasco) to $10.7 \phi / \mathrm{kWh}$ (EPRI). The other immediately obvious differences between studies are the fuel costs ( $\$ 17$ - \$42/ton), and capital costs for feed drying and preparation, gasification, and combined cycle costs.

Another area of significant difference was in raw gas cooling. The EPRI system cools the gasifier product gas to $49^{\circ} \mathrm{C}\left(120^{\circ} \mathrm{F}\right)$ to effect gas cleanup. The clean gas was then re-heated and humidified prior to combustion. These steps require extensive heat transfer equipment. In a study involving a KRW gasifier of similar scale [54], Southern Company Services found that the cost of this heat exchange equipment ranged from $\$ 5$ - \$22 million. Therefore, the cost of the gasification/cleanup sections could be expected to be significantly different. 


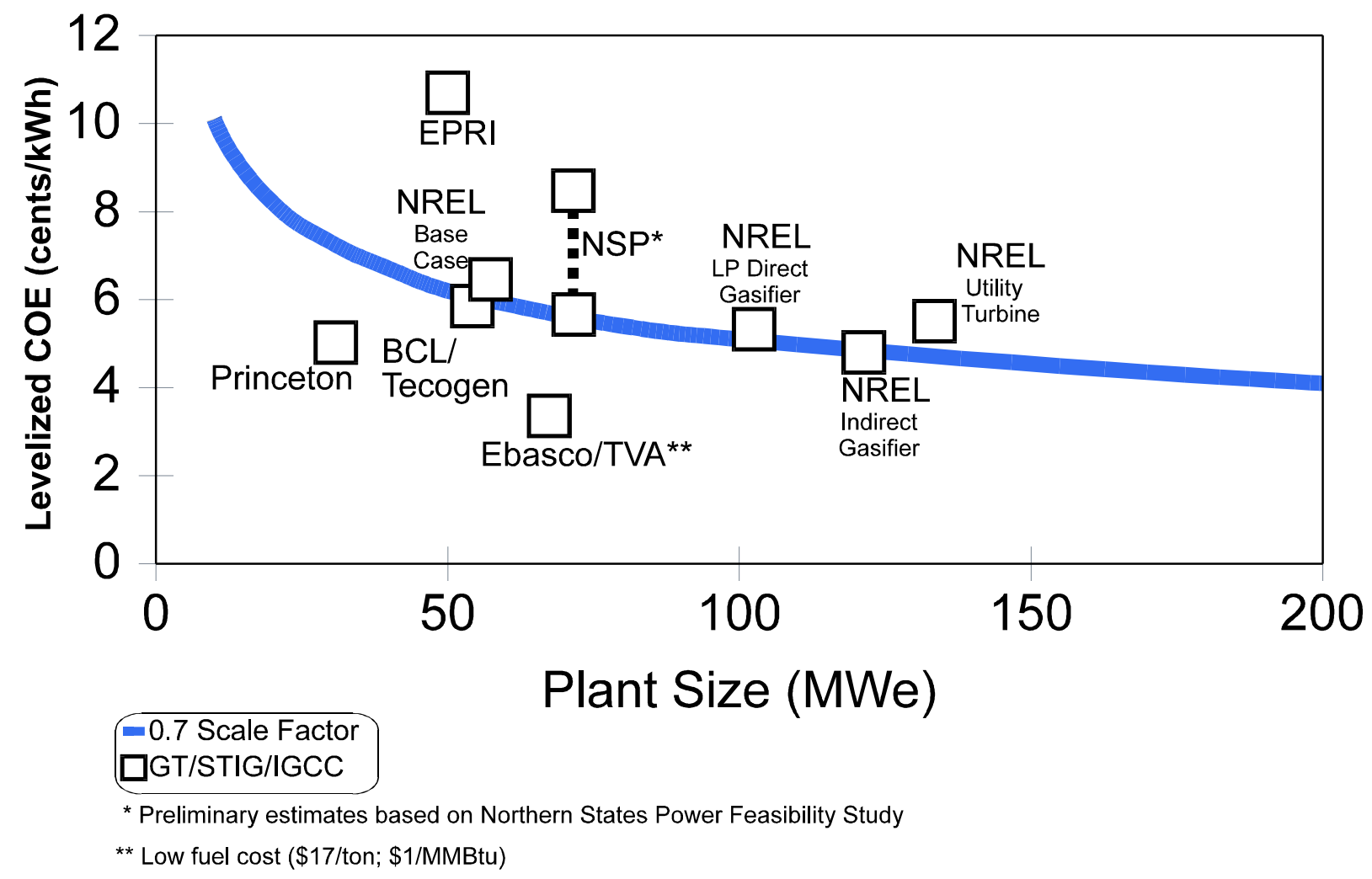

Figure 6: Cost of Electricity vs. Plant Size From Several Studies

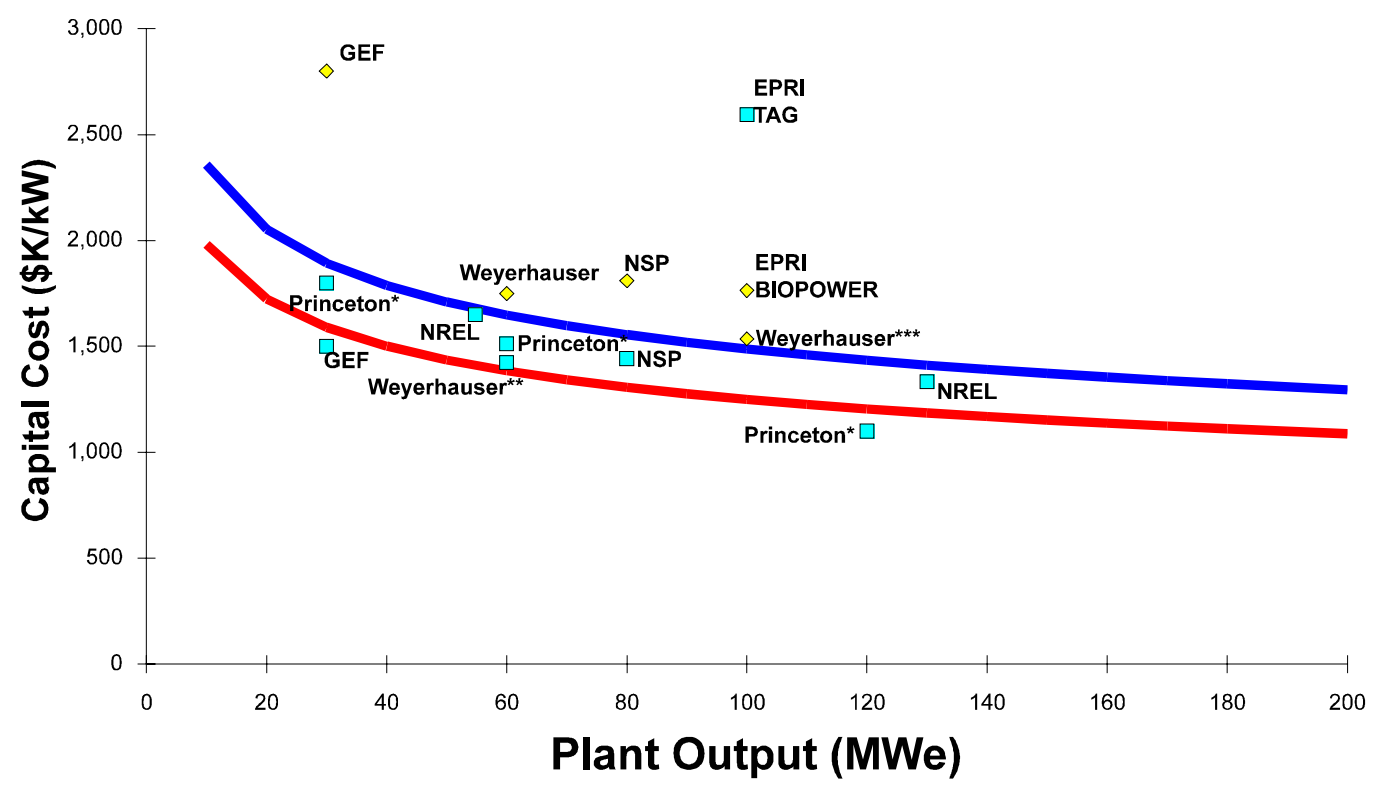

Figure 7: Capital Cost of Biomass IGCC Systems vs. Size From Several Studies 
Table 16: Summary of Technical and Cost Data from Four Biomass IGCC Studies

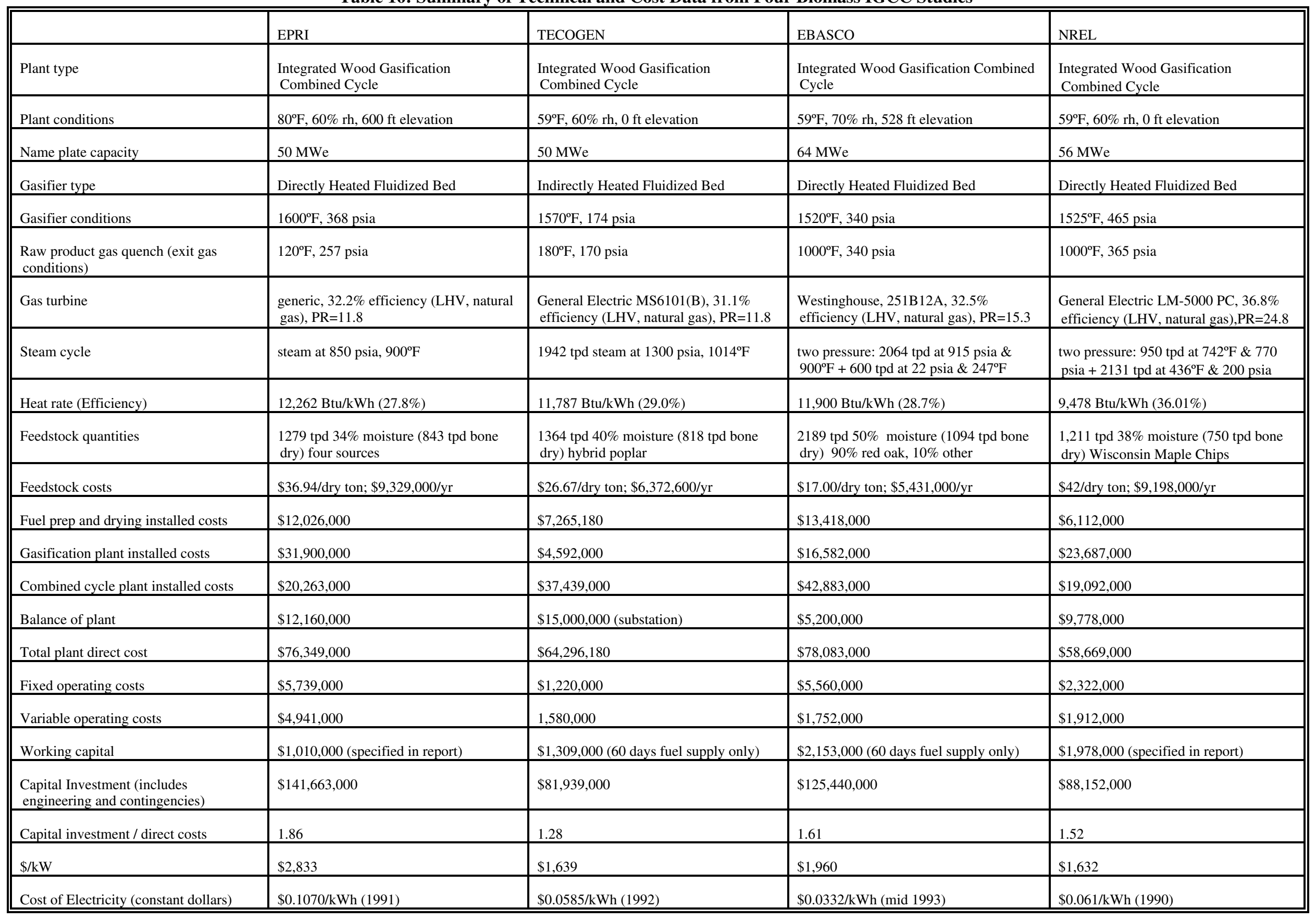




\subsection{Discussion of Design and Cost Comparison \\ 10.1.1 Fuel Costs}

Fuel costs contribute to the electricity cost being high for EPRI and low for Ebasco. Since Ebasco performed a site specific study for TVA, they were able to do a survey of available biomass resources in the area, which determined that a reasonable feedstock cost was $\$ 17 /$ ton. The NREL feed cost of $\$ 42 /$ ton was based on the projections of biomass from a DFSS in its early stages of production. Although this was the highest feed cost, it was partially offset by the high efficiency, and therefore reduced feed rate, of our proposed system. To summarize wood purchase price and quantity of wood purchased, fuel cost per unit of power produced was also calculated. The values from each report are shown in Table 17.

\begin{tabular}{|l|c|c|c|c|}
\hline \multicolumn{5}{|c|}{ Table 17: Fuel Costs of Four Biomass IGCC Studies } \\
\hline & EPRI & Tecogen & Ebasco & NREL \\
\hline Biomass cost, \$/ton & 36.94 & 26.67 & 17.00 & 42.00 \\
\hline $\begin{array}{l}\text { Quantity used, } \\
\text { t/day, bone dry basis }\end{array}$ & 843 & 818 & 1,094 & 750 \\
\hline Net cost, \$/year & $9,328,000$ & $6,372,600$ & $5,431,000$ & $9,198,000$ \\
\hline $\begin{array}{l}\text { Fuel cost per unit output, } \\
\text { \$ kWh }\end{array}$ & 0.0266 & 0.0182 & 0.0121 & 0.0236 \\
\hline
\end{tabular}

\subsubsection{Fuel Preparation and Drying}

The fuel receiving and preparation system in the EPRI study was designed to accept four different feedstocks: urban wood waste, manufacturing wood waste, in-forest wood waste, and agricultural waste. As a result, the feed preparation section of the plant was quite extensive owing to the variety of operations that were included and the amount of feed processing required. The other systems depicted in Figure 6 were designed for single feedstocks. As a consequence, the feed preparation capital costs for the EPRI system were almost twice that of the base case in this study. An examination of the cost detail for the Ebasco study indicates that it includes a substantial amount of ductwork for conveying hot flue gas from the existing power plant to the biomass facility for use in feedstock drying. This ductwork contributes substantially to the cost of this plant section. Exclusion of this ductwork yields a feed preparation and drying section cost similar to that developed by Tecogen and NREL. Table 18 shows the fuel preparation costs for each study.

\begin{tabular}{|l|l|}
\hline \multicolumn{2}{|c|}{ Table 18: Fuel Preparation Costs of Four Biomass IGCC Studies } \\
\hline EPRI & $\$ 12,026,000$ \\
\hline Tecogen & $\$ 7,265,180$ \\
\hline Ebasco & $\$ 13,418,000$ \\
\hline NREL & $\$ 4,897,000$ \\
\hline
\end{tabular}


The following items also contribute to cost discrepancy in fuel preparation:

NREL reduces wood chips to $-1.5 "$ while EPRI, Tecogen and Ebasco reduce wood chips to -0.5 ". Ebasco includes in their cost an additional hammermill to reduce an unspecified amount of wood chips to -1/16" for the gasifier combustor. According to the equipment list, EPRI uses many more conveyors (14) than the other reports (4 to 8). Total conveyor length was not specified in any of the reports. According to Tecogen, conveyors cost $\$ 300$ per foot, FOB. Therefore, cost could significantly be impacted if EPRI's use of more conveyors indicates more total length.

The following factors contribute to cost discrepancies in drying:

The current study employs a smaller installation factor than EPRI, Tecogen or Ebasco as outlined in Table 12. The Ebasco design dries more wood (2189 t/day) and the current design dries less ( $1274 \mathrm{t} /$ day) wood than the other designs. However, the Ebasco study dries wood only to $25 \%$ while the other schemes dry wood to $15 \%$ or lower. Because the heat of vaporization of water was high, evaporating less water has a larger effect on dryer size than does the flowrate of wood when the difference in flowrate was small (as with NREL). When the difference was large, the total water being evaporated was larger even when a smaller percentage of water was removed (as with Ebasco). Therefore, the increased amount of wood that Ebasco dries contributes to an increased dryer cost. A decrease in dryer cost was seen in NREL's scheme.

The EPRI study dryers are smaller in diameter but cost more than dryers used in the other schemes. Although length was not given, cost should depend more on diameter because of difficulties in fabrication and shipping. This indicates that these dryers were not priced in the same manner as in the other reports. The Tecogen design dries the wood chips with recycled flue gas and, therefore, does not use a combustor to heat the air used for drying as do the other designs. It was not clear that this design choice would be workable in an actual system.

\subsubsection{Gasification and Gas Cleaning}

The Installed costs of the gasification and gas cleaning sections in each study are shown in Table 19. Factors contributing to cost discrepancies in the gasification section are listed in the following paragraphs.

\begin{tabular}{|l|l|}
\hline \multicolumn{2}{|l|}{ Table 19: Installed Costs of Gasification and Gas Cleaning Sections } \\
\hline EPRI & $\$ 31,900,000$ \\
\hline Tecogen & $\$ 4,592,000$ \\
\hline Ebasco & $\$ 16,582,000$ \\
\hline NREL & $\$ 23,687,000$ \\
\hline
\end{tabular}

Perhaps the most significant factor affecting cost of this section was that the EPRI design utilizes cold gas cleanup and, therefore, performs extensive indirect gas cooling and reheating. As discussed previously, this can entail substantial equipment cost (\$5-\$22 million). The present study and the Ebasco design perform hot gas cleanup and leave the fuel gas relatively hot. The Tecogen design quenches the fuel gas in a spray tower and leaves the gas relatively cool prior to compression for introduction into the gas turbine combustor. 
The EPRI design uses two lockhoppers in the feeding system, Ebasco and NREL use three, Tecogen uses one. Further, the EPRI design makes a nitrogen-rich stream in a membrane air separation unit for purging the lockhopper system. The oxygen-enriched stream was vented to the atmosphere. The other schemes do not supply an air separation unit.

The Ebasco design incorporates two gasifiers, EPRI, Tecogen, and the NREL aero-derivative cases use only one. Tecogen's gasifier was also significantly smaller than EPRI's and Ebasco's gasifiers because it was indirectly as opposed to directly heated.

Tecogen utilizes an indirectly heated fluidized bed; the other schemes involve directly heated fluidized bed gasifiers. Since an indirectly heated gasifier was sized to accommodate a smaller gas flow, it was smaller than a directly heated gasifier. Thus, Tecogen's gasifier cost could be significantly less. Additional equipment to burn the char and wood to heat an indirectly heated gasifier was necessary. The cost of this additional equipment, however, was $\$ 172,400$ (FOB), which when added to the price of the gasifier $(\$ 86,400, \mathrm{FOB})$ gives a total that was still substantially lower than the gasification cost in this, the Ebasco, or the EPRI study or $(\$ 25,057,000, \$ 16,975,000$, and $\$ 31,900,000$ respectively, installed).

The Tecogen study gasifier operates at 174 psia, while the EPRI and Ebasco gasifiers operate at about 350 psia; the gasifier in the NREL aero-derivative cases operates at 465 psia. The lower operating pressure of the Tecogen gasifier allows for less expensive fabrication and operating costs. These costs do not increase significantly as the pressure was increased from 350 psia to 465 psia.

Gas flowrates per gasifier are highest in the gasifier in the EPRI study, and lowest in the indirectly-heated gasifier. The larger flowrates in the EPRI gasifier account for its larger size and cost. A large amount of steam was added to the Ebasco gasifiers ( $300 \mathrm{t} /$ day per gasifier) compared to EPRI ( $93 \mathrm{t} /$ day) and Tecogen (10.6 t/day). This steam was taken away from the combined cycle, thus producing less electricity.

\subsubsection{Combined Cycle Power Generation}

The gas turbine costs are comparable in each study; differences do not significantly affect difference in capital cost. A summary of the costs of the combined cycle components in each study are shown in Table 20. Factors that contribute to cost differences in the combined cycle system are detailed below.

\begin{tabular}{|l|c|c|c|c|}
\hline \multicolumn{5}{|c|}{ Table 20: Combined Cycle Unit Costs of Four Biomass IGCC Studies } \\
\hline & EPRI & Tecogen & Ebasco & NREL \\
\hline Gas turbine cost, $\$$ & $11,617,000$ & $13,670,000$ & $12,250,000^{*}$ & $13,161,000$ \\
\hline Steam cycle cost, \$ & $3,571,000$ & $7,620,000$ & not specified & $3,133,000$ installed \\
\hline HRSG cost, \$ & 833,000 & $\begin{array}{c}\text { included with steam } \\
\text { turbine cost }\end{array}$ & not specified & $2,208,000$ installed \\
\hline $\begin{array}{l}\text { Combined cycle } \\
\text { installed cost, } \$\end{array}$ & $20,263,000$ & $37,439,000$ & $42,883,000$ & $19,092,000$ \\
\hline
\end{tabular}

* Not specified in report; cost taken from Gas Turbine World [55]

The costs in the Tecogen study include an electrical substation at a cost of $\$ 15,000,000$; the other schemes, with the exception of the greenfield case in this study, do not. 
The combined cycle cost in the Tecogen study includes a balance of plant amount that was reported separately in the other studies.

Ebasco produces more electricity which necessitates a larger and more expensive steam turbine.

The EPRI steam turbine cost was lower than Tecogen's since it was smaller and produces less electricity.

The HRSG in the EPRI study was much lower in cost $(\$ 833,000)$ than in the other studies. The EPRI and Tecogen designs do not extract as much heat from the flue gas as do the Ebasco and NREL studies. The HRSG exit temperature was important; a higher temperature reduces the size and cost of the HRSG, but decreases the amount of steam and thus electricity produced in the steam cycle. In the EPRI design, the HRSG exit temperature was $400^{\circ} \mathrm{F}$; it was $320^{\circ} \mathrm{F}$ in Tecogen's, $203^{\circ} \mathrm{F}$ in Ebasco's and $284^{\circ} \mathrm{F}$ in NREL's. Although this helps explain why the EPRI combined cycle cost was low and Ebasco's high, it leaves the reason for Tecogen's high cost unclear.

These combined cycle installed costs include the gas turbine figures given above:

\subsubsection{Miscellaneous Cost Differences Between Study}

The cost of site development in the Tecogen study was high $(\$ 2,990,000)$ compared to the others $(\$ 500,000$ to $\$ 1,500,000)$. The balance of plant estimate varies from study to study as shown in Table 21. Balance of plant differences add to the total capital investment discrepancies. However, because the components of balance of plant were not specified in any of the studies, it was impossible to determine from which area of the plant these differences arise. The amount added to the total capital investment as contingency is also shown in Table 21.

The high contingency used in the EPRI and Ebasco studies contributes to a higher total capital investment in each case. However, since contingency was a function of purchased equipment price, the source of discrepancy in contingency was in the equipment of each section already mentioned.

\begin{tabular}{|l|l|l|l|}
\hline \multicolumn{3}{|c|}{ Table 21: Balance of Plant and Contingency Estimates of Four Biomass IGCC Studies } \\
\hline & Balance of Plant Estimate & Contingency & $\begin{array}{l}\text { Formulation for calculating } \\
\text { contingency }\end{array}$ \\
\hline EPRI & $\$ 12,160,000$ & $\$ 22,397,000$ & $15 \%$ of installed equipment costs \\
\hline Tecogen & $\$ 0$ & $\$ 6,069,000$ & $\begin{array}{l}13 \% \text { of CCPP installed costs }+75 \% \text { of } \\
\text { other installed costs }\end{array}$ \\
\hline Ebasco & $\begin{array}{l}\$ 5,200,000 \text { (appears to be only } \\
\text { for the combined cycle plant) }\end{array}$ & $\$ 18,687,000$ & $20 \%$ of installed equipment costs \\
\hline NREL & $\$ 9,778,000$ & $\$ 9,952,000$ & $\begin{array}{l}15 \% \text { of installed equipment costs plus } \\
\text { general plant facilities }\end{array}$ \\
\hline
\end{tabular}

A comparison of the total capital investment, the direct costs and the ratio of the two indicates the degree to which the costs of a study are influenced by equipment or indirect costs such as installation and contingencies. This comparison can be seen in Table 22 . 


\begin{tabular}{|l|r|r|c|}
\hline \multicolumn{2}{|c|}{ Table 22: Total Capital Investment and Direct Costs in Four Biomass IGCC Studies } \\
\hline & $\begin{array}{c}\text { Total capital investment } \\
(\mathrm{TCI})\end{array}$ & Direct costs & $\begin{array}{c}\text { ratio of TCI to } \\
\text { direct costs }\end{array}$ \\
\hline EPRI & $\$ 141,663,000$ & $\$ 76,349,000$ & 1.86 \\
\hline Tecogen & $\$ 81,939,000$ & $\$ 64,296,180$ & 1.28 \\
\hline Ebasco & $\$ 125,440,000$ & $\$ 78,083,000$ & 1.61 \\
\hline NREL & $\$ 88,152,000$ & $\$ 58,669,000$ & 1.50 \\
\hline
\end{tabular}

Since indirect costs are usually calculated as a percentage of direct costs, a higher ratio of capital investment to direct costs indicates that higher factors were used to calculate items such as installation and working capital. With the exception of the present study, the direct costs are similar. Therefore, the discrepancy in the ratio was due to the calculation of indirect costs. The high ratio in the EPRI study indicates that the higher capital estimate was due to higher indirect costs. Similarly, the Tecogen estimate uses low factors to calculate indirect costs. The difference in total capital investment between the Ebasco and NREL studies was a result of the difference in direct costs, rather than the factors used to calculate indirect costs.. According to Peters and Timmerhaus [56], the ratio was 1.66 for a solid-fluid processing plant

Ebasco includes a substantial additional cost labeled as "Construction" in the capital cost for the combined cycle. This cost was not mentioned in the other parts of the plant or in the other studies and was therefore assumed to be included as a direct cost. Usually, construction was mentioned as an indirect cost.

\subsubsection{Additional Factors Affecting Cost of Electricity}

The heating value of the product gas into the gas turbine was highest for Tecogen $(459 \mathrm{Btu} / \mathrm{scf}$ ) because an indirectly heated gasifier was used. All other heating values are similar: EPRI's was $154 \mathrm{Btu} / \mathrm{scf}$, Ebasco's was $132 \mathrm{Btu} / \mathrm{scf}$, NREL's was $126 \mathrm{Btu} / \mathrm{scf}$. This impacts power output from the gas turbine and plant efficiency, and thus feed cost.

The capital investment in the EPRI study was very high in relation to the amount of electricity produced. The Ebasco study system produces more electricity, $64 \mathrm{MW}_{\mathrm{e}}$, than do the other studies which produce 50 $\mathrm{MW}_{\mathrm{e}}$. The Ebasco design was for a TVA power plant and therefore does not include federal taxes.

Ebasco uses more steam in gasification than do the other schemes. This steam was taken from the steam turbine, and thus less electricity was produced. Therefore, Ebasco could be making even more power than they currently propose, further reducing the cost of electricity.

The Tecogen and especially EPRI designs do not extract all available heat in the HRSG from flue gas to produce steam. Ebasco extracts more heat than does the NREL study.

Each scheme utilizes tar generated in gasification differently. If the tar was somehow removed from the fuel gas and combusted, more steam will be available for the combined cycle plant. EPRI disposes the tar as waste, thus not generating additional steam and incurring the cost of wastewater treatment and tar disposal. Tecogen combusts the tar in a separate combustor, thus incurring additional equipment cost but 
producing more steam. Ebasco leaves the tar in the fuel gas which at $1000^{\circ} \mathrm{F}$ reduces the chances of the tar accumulating on the ceramic candle filters. The tars are then burned in the gas turbine. The present study cracks the tars in a separate reactor and burns the resulting products in the gas turbine.

The price of land does not significantly affect the price of electricity. EPRI and Tecogen buy land for about one million dollars each, while Ebasco and the present base case do not include land in their estimates. In the EPRI study 140 acres are purchased; Tecogen assumes that nine acres are purchased.

\subsection{Normalized Cost of Electricity}

The above analysis aside, there remained a wide variability between studies in the ratio of total capital investment to direct costs $(1.28$ - 1.86). To eliminate the effect of this and other assumptions and factors, we performed "normalized" cost of electricity calculations for each study. To do this, we utilized the direct capital costs from each study (converted to 1990 dollars), then calculated a cost of electricity utilizing the other assumptions (feed costs, contingencies, etc.) and methods employed in our study. All of the normalized cases assumed a greenfield plant basis and thus also included costs for land, site preparation, and an electrical substation. The results of this normalization, presented in Table 23, show that all studies except EPRI's yield costs of electricity in the $5-7 \phi / \mathrm{kWh}$ range.

Table 23: Normalized Cost Comparison of Four Biomass IGCC Studies *

\begin{tabular}{|c|c|c|c|c|c|c|}
\hline & EPRI & $\begin{array}{l}\text { Tecoge } \\
\mathrm{n}\end{array}$ & Ebasco & $\begin{array}{l}\text { NREL } \\
\text { case } 1\end{array}$ & $\begin{array}{l}\text { NREL } \\
\text { case } 2\end{array}$ & $\begin{array}{l}\text { NREL } \\
\text { case } 3\end{array}$ \\
\hline $\begin{array}{l}\text { Output, } \\
\text { MWe }\end{array}$ & 50 & 50 & 64 & 56 & 122 & 105 \\
\hline $\begin{array}{l}\text { Efficiency, } \\
\%, \text { HHV }\end{array}$ & 27.84 & 22.96 & 28.69 & 36.01 & 35.40 & 37.9 \\
\hline $\begin{array}{l}\text { Capital Cost, } \\
\$ / \mathrm{kW}\end{array}$ & 3,005 & 1,850 & 1,706 & 1,588 & 1,108 & 1,350 \\
\hline \multicolumn{7}{|c|}{ Cost of Electricity (Constant \$1990) } \\
\hline $\begin{array}{l}\text { Capital, } \\
\notin / \mathrm{kWh}\end{array}$ & 4.2 & 2.6 & 2.4 & 2.64 & 1.8 & 2.25 \\
\hline $\begin{array}{l}\text { Fuel, } \\
\notin / \mathrm{kWh}\end{array}$ & 4.1 & 2.1 & 1.7 & 2.36 & 2.4 & 2.21 \\
\hline $\begin{array}{l}\mathrm{O} \& \mathrm{M}, \\
\notin / \mathrm{kWh}\end{array}$ & 3.0 & 2.9 & 3.0 & 1.09 & 1.5 & 0.98 \\
\hline $\begin{array}{l}\mathrm{COE} \\
\phi / \mathrm{kWh}\end{array}$ & 11.3 & 7.6 & 7.1 & 6.1 & 5.66 & 5.43 \\
\hline
\end{tabular}

* NREL case 1 refers to the high pressure, air-blown gasifier with aero-derivative turbine.

NREL case 2 refers to the low pressure, indirectly-heated gasifier with an utility gas turbine. NREL case 3 refers to the low pressure, air-blown gasifier with an utility gas turbine. 


\subsection{Analysis, Discussion, and Conclusions}

Advanced utilization systems currently under development hold the potential for even more significant improvements in cost and efficiency than the systems examined here. It is important to continue development and demonstration of current technology and dedicated feedstock supply systems to be positioned to take advantage of these advances.

To put the results of this study into perspective, and to help visualize potential benefits of future work, Figure 8 was created. This figure depicts the inter-relation of system efficiency, system size (or feedstock availability), and the cost of electricity at two different feedstock costs. The figure was constructed by scaling the base case system costs and generating "iso-COE" lines at various feedstock availability levels. The base and advanced utility turbine cases from the current study are indicated on the figure.

It is clear from this figure that the greatest reductions in COE from biomass IGCC systems will come from increasing both system efficiency and size. Simply increasing the efficiency of the base case by even an optimistic 10 points of efficiency, would only reduce the resulting cost of electricity by about $1 \phi / \mathrm{kWh}$. However, the same increase in efficiency coupled with a threefold size (feedstock availability) increase yields double the reduction in electricity cost. Similarly, except at very low efficiencies, increases in system size alone result in relatively small reductions in cost of electricity. Therefore, to maximize COE reductions, it is necessary to proceed in a "diagonal" manner across the figure, increasing efficiency and system size (feedstock availability). Thus, significant incentive exists for the continued development of both utilization technologies (turbines, cycles, fuel cells) and feedstock supply systems.

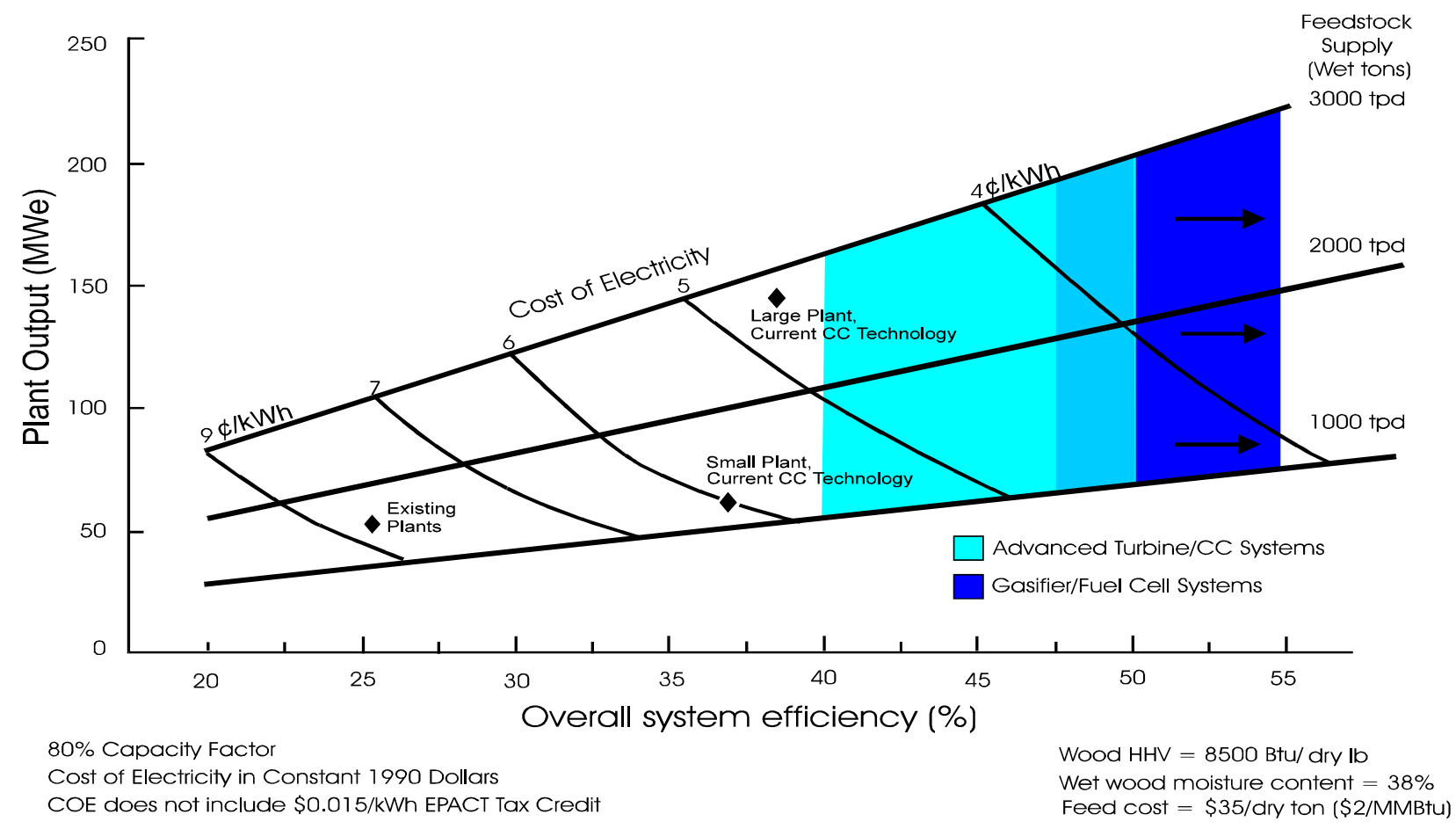

Figure 8: Relationship of System Size, Efficiency, and Cost of Electricity 
The alternative, and contrary to this conclusion, is to pursue low-cost feedstocks such as may be available to smaller scale, distributed generation systems. The studies discussed in this report clearly point out the importance of feedstock to cost of electricity comprising as much as one third of the overall electricity cost in some cases. Successful deployment of small-scale systems will also depend, however, on the availability of modular, high efficiency, low-maintenance power production devices such as fuel cells.

Low pressure gasification is shown in this report to be a economically vaible even at relatively large scales. The cost of low-temperature gas cleanup and compression is more than offset by the substantially lower cost of the gasifier itself. Scale-up and demonstration efforts underway in the Biomass Power Program will help to determine how accurate these relative costs are. Low pressure gasification is also preferrable at small-scale, and for most fuel cell systems.

A number of other useful conclusions can be drawn from this study. It was clear that, despite the notable efficiency increase from indirect quench of the fuel gas, the resulting cost of electricity does not warrant the increased capital expenditure. Conversely, if technical considerations require a fuel gas with an increased heating value, an indirect quench will not substantially increase the cost of electricity. However, the use of an indirectly-heated gasifier (such as that developed by BCL) is more likely if a higher quality fuel gas is needed.

The most promising alternative is to use an advanced utility-scale gas turbine such as the GE MS-6101FA. Such a system benefits not only from economy of scale, but from the increased turbine efficiency and, perhaps most significantly, the re-heat steam cycle that is feasible at this scale and turbine exhaust temperature. Historically, generating systems of this scale $\left(>100 \mathrm{MW}_{\mathrm{e}}\right)$ were deemed infeasible for biomass-based systems because of the associated feed requirements. However, the use of advanced combined-cycle technology reduces fuel requirements to manageable levels because of the striking increase in generating efficiency.

Complementary to this trend is the development of dedicated feedstock supply systems that are intended to sustainably supply larger quantities of feedstock than were heretofore available. Properly managed, these trends are positioned to merge and provide a new generation of high-efficiency and cost-competitive biomass-based electricity generating stations.

\subsection{Comments on Advanced Cycles}

The Department of Energy is pursuing commercial deployment of advanced gas turbines and combined cycles systems through its Advanced Turbine Systems (ATS) program. Private and utility development is being fostered through the Collaborative Advanced Gas Turbine (CAGT) program. These efforts have as their mutual goal combined cycle systems with efficiencies of $60 \%$ (natural gas, LHV basis). This translates into biomass IGCC system efficiencies on the order of $50 \%$ on a higher heating value basis. An examination of Figure 8 reveals that this represents at least a $1 \varnothing / \mathrm{kWh}$ reduction in the cost of electricity from such systems.

An avenue for even greater system efficiency and reduced electricity costs exists in integration of biomass gasification with fuel cell systems. Fuel cells, in particular molten carbonate fuel cells (MCFC's), are in the early demonstration stages with coal gasifiers. These tests will determine the tolerance of the fuel cells for contaminants contained in actual fuel gas streams as well as the lifetime 
and thus costs of cells so operated. These gasification fuel cell systems (IGFC's) are projected to have overall coal-to-electricity efficiencies in excess of $50 \%$. Biomass gasifiers have potentially significant advantages over coal gasifier for these applications. In the Biomass Power Program 5-year plan, demonstration of a MCFC with a biomass gasifier is scheduled for 1998.

Sulfur is the contaminant of most concern for fuel cell applications. However, because most biomass feedstocks are substantially lower in sulfur than virtually any coal, biomass systems have a considerable advantage. Although biomass is higher in alkali species it's likely that MCFC's are much more tolerant of alkali than are gas turbines. This is especially true of potassium (the majority of biomass alkali) since the molten carbonates are largely potassium salts. This of course needs to be experimentally verified. It is possible that significant amounts of potassium in the fuel gas could upset the mixed salt balance in the electrolyte. However, high temperature alkali control procedures adequate for turbines should be more than satisfactory for fuel cells. Therefore, the current generation biomass-IGFC systems are likely to have similar or possibly slightly higher efficiencies than equivalent coal-based systems.

Biomass gasifiers may be ideally suited to certain advanced IGFC systems as well. A hypothetical IGFC system was identified in a 1989 paper [57] with a projected efficiency in excess of $65 \%$. One of the major keys to realization of such systems is the close matching of the gasifier to fuel cell operating conditions. The key gasifier characteristics necessary for this matching were identified in the paper as:

- gasifier temperature less than maximum MCFC temperature $704^{\circ} \mathrm{C}\left(1300^{\circ} \mathrm{F}\right)$,

- gasifier pressure less than MCFC pressure 0.6 MPa (6 atm.),

- maximal hydrogen content in fuel gas,

- no tars in the fuel gas,

- no combustion in the gasifier.

Biomass gasifiers are much more likely to meet these criteria than are coal gasifiers because of their feed characteristics and reactivity of the feed. Further, with the use of internally reforming fuel cells, the maximal hydrogen criterion could be expanded to include methane. This further favors biomass gasification. In the coming months an investigation will be completed which assesses the performance of biomass gasifier-fuel cell systems. 
Appendix A: Capital Cost Details for the Systems Studied 
Appendix A-1

Capital Cost Details for the High Pressure Gasifier

Integrated with the Aero-Derivative Gas Turbine

ELECTRIC POWER GENERATION COST - Version 1.11

56 MW Integrated biomass gasification combined cycle power plant

High pressure directly-heated biomass gasifier

Cost of Electricity - Levelized
Capital Charges
Fuel costs
Operating \& Maintenance

Total Cost of Electricity

CAPITAL REQUIREMENTS (Dec

1990 Dollars)

Total Plant Investment

PLANT SECTION DESCRIPTION

PROCESS

CONT, \%

Wood Handling

Wood Drying

Gasification

Particulate Cleanup

Quench System

Gas Turbine

HRSG

Steam Cycle

Air Boost Compressor

Char combustor

B.O.P.

$50.3 \mathrm{MWe}$

8.95 MWe $\begin{array}{ll}\begin{array}{l}\text { Current } \$ \\ \text { mills/kWh }\end{array} & \begin{array}{c}\text { Constant } \$ \\ \text { mills/kWh }\end{array}\end{array}$

$\begin{array}{ll}37.5 & 26.4 \\ 28.6 & 23.6 \\ 13.1 & 10.9\end{array}$

$79.1 \quad 61.0$

Subtotal, Process Plant Cost

\begin{tabular}{|c|c|}
\hline $\begin{array}{c}\text { COST, K\$ } \\
\text { W/O CONT }\end{array}$ & $\begin{array}{l}\text { COST } \\
\$ / k W\end{array}$ \\
\hline$\$ 2,173$ & $\$ 39$ \\
\hline$\$ 2,724$ & $\$ 49$ \\
\hline$\$ 20,972$ & $\$ 378$ \\
\hline$\$ 2,700$ & $\$ 49$ \\
\hline & $\$ 0$ \\
\hline$\$ 15$ & $\$ 0$ \\
\hline$\$ 13,161$ & $\$ 262$ \\
\hline$\$ 2,208$ & $\$ 63$ \\
\hline$\$ 3,133$ & $\$ 350$ \\
\hline$\$ 590$ & $\$ 11$ \\
\hline$\$ 1,215$ & $\$ 22$ \\
\hline$\$ 9,778$ & $\$ 176$ \\
\hline$\$ 58,669$ & $\$ 1,057$ \\
\hline$\$ 5,867$ & \\
\hline$\$ 8,800$ & \\
\hline$\$ 0$ & \\
\hline$\$ 9,680$ & \\
\hline$\$ 83,017$ & \\
\hline$\$ 200$ & \\
\hline$\$ 83,216$ & \\
\hline$\$ 293$ & \\
\hline$\$ 0$ & \\
\hline$\$ 2,250$ & \\
\hline$\$ 415$ & \\
\hline$\$ 1,978$ & \\
\hline$\$ 0$ & \\
\hline$\$ 88,152$ & $\$ 1,588$ \\
\hline
\end{tabular}

General Plant Facilities

Engineering Fees

Process Contingency (Using contingencies listed above)

Project Contingency,

Total Plant Cost (TPC)

Plant Construction Period,

Construction Interest Rate,

Adjustment for Interest and Inflation

2 Years (1 or more)

$4.5 \%$

Prepaid Royalties

Total Plant Investment (TPI)

$\$ 88,152$

Startup Costs

Spare Parts

Working Capital

Land,

0 Acres

Total Capital Requirement (TCR) 43 
Appendix A-2

Capital Cost Details for the High Pressure Gasifier

Integrated with the Utility Gas Turbine

ELECTRIC POWER GENERATION COST - Version 1.11

$132 \mathrm{MW}$ Integrated biomass gasification combined cycle power plant High pressure directly-heated biomass gasifier
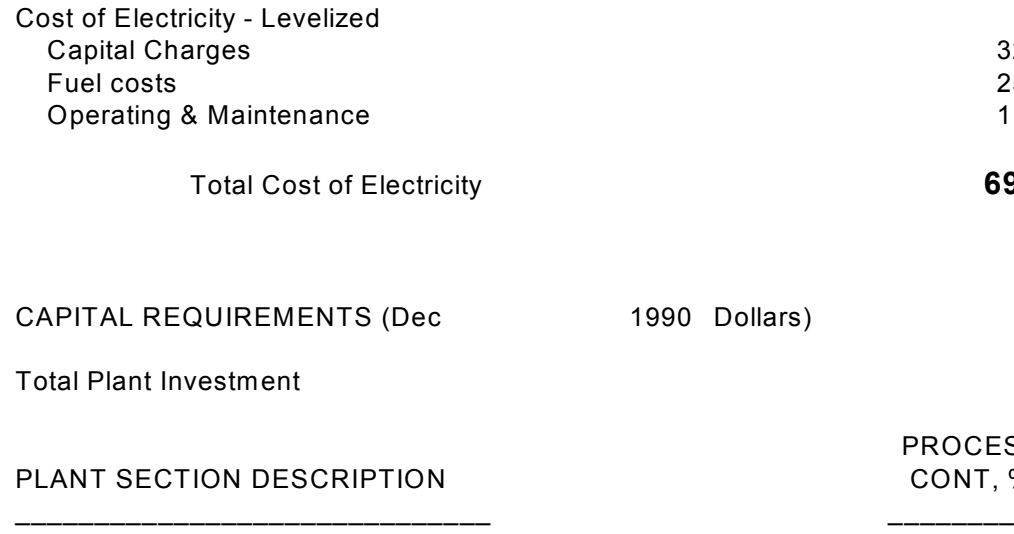

$\begin{array}{ll}\text { Current } \$ & \text { Constant } \$ \\ \text { mills/kWh } & \text { mills/kWh }\end{array}$

$\begin{array}{rr}32.3 & 22.8 \\ 25.9 & 21.4 \\ 11.6 & 9.6\end{array}$

69.9

53.9
Subtotal, Process Plant Cost

General Plant Facilities

Engineering Fees

Process Contingency (Using contingencies listed above)

Project Contingency,

$\begin{array}{rr}\begin{array}{c}\text { COST, K\$ } \\ \text { W/O CONT } \\ (\$ 1,000)\end{array} & \begin{array}{c}\text { COST } \\ \$ / \mathrm{kW}\end{array} \\ & \\ \$ 4,346 & \$ 33 \\ \$ 5,448 & \$ 41 \\ \$ 44,475 & \$ 338 \\ \$ 5,400 & \$ 41 \\ & \$ 0 \\ \$ 30 & \$ 0 \\ \$ 17,220 & \$ 185 \\ \$ 8,000 & \$ 61 \\ \$ 11,675 & \$ 250 \\ \$ 1,180 & \$ 9 \\ \$ 2,282 & \$ 17 \\ \$ 20,011 & \$ 152 \\ & \\ \$ 120,067 & \$ 911\end{array}$

$\$ 12,007$

$\$ 18,010$

$\$ 0$

$\$ 19,811$

$\$ 169,895$

$\$ 408$

$\$ 170,303$

$\$ 600$

$\$ 4,649$

$\$ 849$

$\$ 4,251$

$\$ 0$

$\$ 180,653$ 
Appendix A-3

Capital Cost Details for the High Pressure Gasifier

Integrated with the Aero-Derivative Gas Turbine, Greenfield Case

ELECTRIC POWER GENERATION COST - Version 1.11

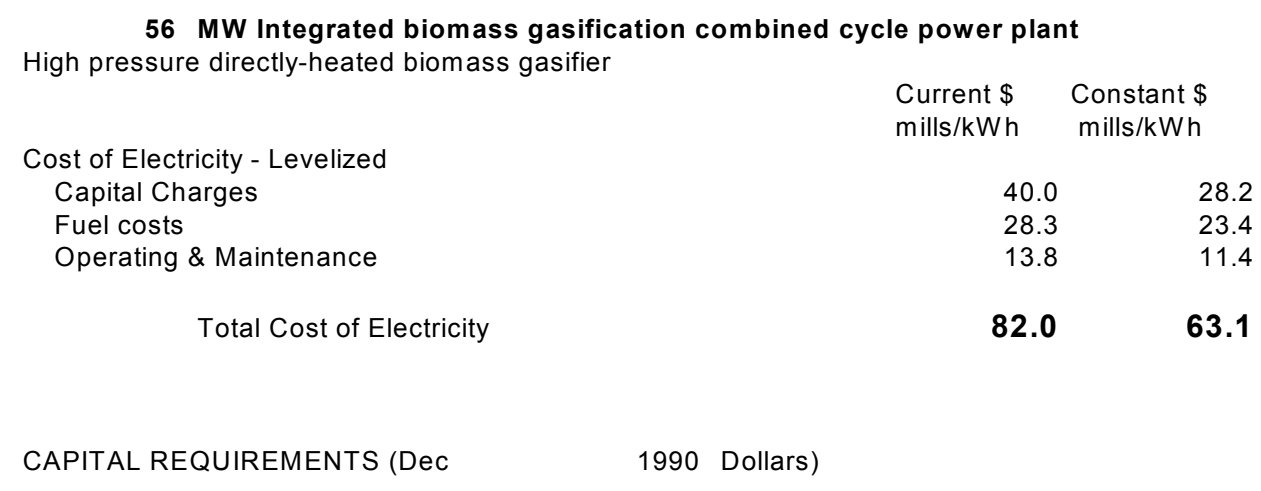

Total Plant Investment

CONT, \%

Wood Handling

Wood Drying

Gasification

Particulate Cleanup

Quench System

Gas Turbine

HRSG

Steam Cycle

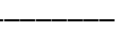

Air Boost Compressor

Char combustor

B.O.P.

Substation

$\begin{gathered}\text { PROCESS } \\ \text { CONT, \% }\end{gathered}$
-

Subtotal, Process Plant Cost

\begin{tabular}{rr}
$\begin{array}{r}\text { COST, K\$ } \\
\text { W/O CONT } \\
(\$ 1,000)\end{array}$ & $\begin{array}{c}\text { COST } \\
\$ / \mathrm{kW}\end{array}$ \\
\cline { 2 - 2 }$\$ 2,173$ & \\
$\$ 2,724$ & $\$ 39$ \\
$\$ 20,972$ & $\$ 375$ \\
$\$ 2,700$ & $\$ 48$ \\
& $\$ 0$ \\
$\$ 15$ & $\$ 0$ \\
$\$ 13,161$ & $\$ 262$ \\
$\$ 2,208$ & $\$ 63$ \\
$\$ 3,133$ & $\$ 350$ \\
$\$ 590$ & $\$ 11$ \\
$\$ 1,215$ & $\$ 22$ \\
$\$ 9,778$ & $\$ 175$ \\
$\$ 3,958$ & $\$ 71$ \\
&
\end{tabular}

General Plant Facilities

$\$ 62,627$

$\$ 1,118$

Engineering Fees

$\$ 6,263$

$\$ 9,394$

Process Contingency (Using contingencies listed above)

Project Contingency,

Plant Construction Period

Construction Interest Rate,

Adjustment for Interest and Inflation

2 Years (1 or more)

$4.5 \%$

Total Plant Investment (TPI)

Prepaid Royalties

$\$ 313$

Initial Catalyst and Chemical Inventory

$\$ 2,382$

$\$ 443$

$\$ 1,982$

$\$ 1,000$

Working Capital

Land,

0 Acres

$\$ 94,951$ 
Appendix A-4

Capital Cost Details for the Low Pressure Indirectly-Heated

Gasifier Integrated with the Utility Gas Turbine

Capital Cost Details for the Low Pressure Indirectly-Heated Gasifier Integrated with an Industrial Gas Turbine

122 MW Integrated biomass gasification combined cycle power plant

$\begin{array}{crr} & \begin{array}{c}\text { Current \$ } \\ \text { mills/kWh }\end{array} & \begin{array}{c}\text { Constant } \$ \\ \mathrm{mills} / \mathrm{kW} \mathrm{h}\end{array} \\ \text { Cost of Electricity - Levelized } & 26.1 & 18.4 \\ \text { Capital Charges } & 28.4 & 23.5 \\ \text { Fuel costs } & 17.7 & 14.7 \\ \text { Operating \& Maintenance } & \mathbf{7 2 . 2} & \mathbf{5 6 . 6} \\ \text { Total Cost of Electricity } & \end{array}$

CAPITAL REQUIREMENTS (December

1990 Dollars)

Total Plant Investment

Wood Handling

Wood Drying

Gasification

Particulate Cleanup

Tar Cracker

Quench System

Gas Turbine

HRSG

Steam Cycle

5 Stage Boost Compressor

B.O.P.

82.07 MWe

$55.08 \mathrm{MWe}$

\section{PLANT SECTION DESCRIPTION}

Subtotal, Process Plant Cost

PROCESS

CONT, \%

$--------$

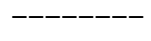

General Plant Facilities

Engineering Fees

Process Contingency (Using contingencies listed above)

Project Contingency,

$15 \%$ Proc PIt \& Gen PIt Fac

Total Plant Cost (TPC)

2 Years

$4.5 \%$

Plant Construction Period,

Construction Interest Rate,

Adjustment for Interest and Inflation

Total Plant Investment (TPI)

Prepaid Royalties

Initial Catalyst and Chemical Inventory

Startup Costs

Spare Parts

Working Capital

Land,

0 Acres

Total Capital Requirement (TCR)

\begin{tabular}{rr} 
COST, K\$ & \multicolumn{1}{c}{ COST } \\
W/OCONT & \multicolumn{2}{c}{$\$ / \mathrm{kW}$} \\
$(\$ 1,000)$ & ------ \\
$\$ 4,400$ & $\$ 36$ \\
$\$ 5,448$ & $\$ 45$ \\
$\$ 14,185$ & $\$ 116$ \\
$\$ 5,400$ & $\$ 44$ \\
$\$ 454$ & $\$ 4$ \\
$\$ 30$ & $\$ 0$ \\
$\$ 17,850$ & $\$ 217$ \\
$\$ 7,686$ & $\$ 63$ \\
$\$ 12,668$ & $\$ 230$ \\
$\$ 5,691$ & $\$ 47$ \\
$\$ 14,762$ & $\$ 121$ \\
& \\
$\$ 88,575$ & $\$ 726$
\end{tabular}

$\$ 8,857$

$\$ 13,286$

$\$ 0$
$\$ 14,615$

$\$ 125,333$

$\$ 301$

$\$ 125,635$

$\$ 443$

$\$ 0$

$\$ 4,081$

$\$ 627$

$\$ 4,425$

$\$ 0$

$\$ 135,211$

$\$ 1,108$ 
Appendix A-5

Capital Cost Details for the Low Pressure Direct-Fired

Gasifier Integrated with the Utility Gas Turbine

105 MW Integrated biomass gasification combined cycle power plant Low pressure directly-heated biomass gasifier

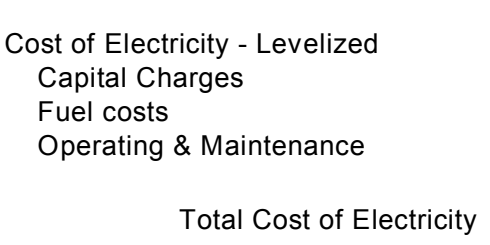

\begin{tabular}{rr}
$\begin{array}{l}\text { Current \$ } \\
\text { mills/kWh }\end{array}$ & \multicolumn{2}{c}{$\begin{array}{c}\text { Constant \$ills/kWh } \\
\text { milk }\end{array}$} \\
31.8 & 22.5 \\
26.7 & 22.1 \\
11.8 & 9.8 \\
& \\
$\mathbf{7 0 . 3}$ & $\mathbf{5 4 . 3}$
\end{tabular}

$72.8 \mathrm{MWe}$

47.6 MWe
Subtotal, Process Plant Cost

General Plant Facilities

Engineering Fees

Process Contingency (Using contingencies listed above)

Project Contingency,

$15 \%$ Proc PIt \& Gen PIt Fac

\begin{tabular}{rr} 
COST, K\$ \\
W/O CONT \\
$(\$ 1,000)$ & $\begin{array}{c}\text { COST } \\
\$ / \mathrm{kW}\end{array}$ \\
\cline { 2 - 2 }$\$ 3,478$ & \\
$\$ 4,360$ & $\$ 33$ \\
$\$ 33,481$ & $\$ 319$ \\
$\$ 17,220$ & $\$ 237$ \\
$\$ 8,000$ & $\$ 76$ \\
$\$ 11,900$ & $\$ 250$ \\
$\$ 15,688$ & $\$ 215$
\end{tabular}

$\$ 94,127$ $\$ 896$

Total Plant Cost (TPC)

$\$ 9,413$

$\$ 14,119$

$\$ 0$

$\$ 15,531$

$\$ 133,190$

Plant Construction Period, Construction Interest Rate,

2 Years (1 or more)

Adjustment for Interest and Inflation

$4.5 \%$

$\$ 320$

Total Plant Investment (TPI)

$\$ 133,510$

$\$ 471$

Initial Catalyst and Chemical Inventory

$\$ 3,680$

$\$ 666$

Startup Costs

$\$ 3,472$

Working Capital

Land,

0 Acres

$\$ 0$

Total Capital Requirement (TCR)

$\$ 141,798$

$\$ 1,350$ 
Appendix B: Details of Biomass IGCC Cost Study Comparison 


\section{CAPITAL EXPENDITURES}

\begin{tabular}{|c|c|c|c|c|c|c|c|c|}
\hline & EPRI & $\begin{array}{l}\text { costs } \\
(1991)\end{array}$ & TECOGEN & $\begin{array}{l}\text { costs } \\
(1992)\end{array}$ & EBASCO & $\begin{array}{l}\text { costs } \\
(1993)\end{array}$ & NREL & $\begin{array}{l}\text { costs } \\
(1990)\end{array}$ \\
\hline \multicolumn{9}{|l|}{ FEEDSTOCK } \\
\hline $\begin{array}{l}\text { source and condition at } \\
\text { plant }\end{array}$ & $\begin{array}{l}\text { four sources, many } \\
\text { different woods; 1/2" } \\
\text { chips }\end{array}$ & & hybrid poplar; $1 / 2$ " chips & & $\begin{array}{l}90 \% \text { red oak, various } \\
\text { sources not mentioned; } \\
2 " \text { chips }\end{array}$ & & $\begin{array}{l}\text { Wisconsin Maple Chips } \\
2^{\prime \prime}\end{array}$ & \\
\hline moisture content & $\begin{array}{l}\text { AR wood has } 34 \mathrm{wt} \% \\
\text { moisture, dried to } 15 \%\end{array}$ & & $\begin{array}{l}\text { AR wood has } 40 \mathrm{wt} \% \\
\text { moisture, dried to } 15 \%\end{array}$ & & $\begin{array}{l}\text { AR wood has } 50 \mathrm{wt} \% \\
\text { moisture, dried to } 25 \%\end{array}$ & & $\begin{array}{l}\text { AR wood has } 38 \mathrm{wt} \% \\
\text { moisture, dried to } 15 \%\end{array}$ & \\
\hline wood bought & $\begin{array}{l}1279 \text { tpd AR wood ( } 843 \\
\text { tpd bone dry) }\end{array}$ & & $\begin{array}{l}1364 \text { tpd AR wood ( } 818 \\
\text { tpd bone dry) }\end{array}$ & & $\begin{array}{l}2189 \text { tpd AR wood } \\
\text { (1094 tpd bone dry) }\end{array}$ & & $\begin{array}{l}1274 \text { tpd AR wood ( } 789 \\
\text { tpd bone dry) }\end{array}$ & \\
\hline cost & & $\begin{array}{l}\$ 36.94 / \text { dry ton; } \\
\$ 9,328,000 / \mathrm{yr}\end{array}$ & & $\begin{array}{l}\$ 26.67 / \text { dry ton; } \\
\$ 6,372,600 / y r\end{array}$ & & $\begin{array}{l}\$ 32.80 / \text { dry ton; } \\
\$ 10,478,000 / y \\
\text { r }\end{array}$ & & $\begin{array}{l}\$ 42 / \text { dry ton; } \\
\$ 9,198,000 / \mathrm{yr}\end{array}$ \\
\hline \multicolumn{9}{|l|}{$\begin{array}{l}\text { FUEL } \\
\text { PREPARATION } \\
\end{array}$} \\
\hline magnetic separator & & not specified & & not specified & & not specified & & $\$ 8,300$ \\
\hline screen and hammermill & screen used & not specified & $\begin{array}{l}\text { screen and hammermill } \\
\text { (hogger) used }\end{array}$ & $\begin{array}{l}\text { included; } \\
\$ 40,000\end{array}$ & $\begin{array}{l}\text { two hammermills to } \\
\text { reduce chips: one to - } \\
1 / 2 " \text {, one to }-1 / 16 \text { " } \\
\text { (1/16" burned to heat } \\
\text { drying gas) }\end{array}$ & not specified & $\begin{array}{l}\text { screen and hammermill } \\
\text { (hogger) used }\end{array}$ & $\$ 59,540$ \\
\hline prepared chip size & $-0.5^{\prime \prime}$ & & $-0.5^{\prime \prime}$ & & $-0.5^{\prime \prime}$ & & $-1.5^{\prime \prime}$ & \\
\hline electrical installation & & $\begin{array}{l}\text { included; } \\
\$ 927,900 \\
\end{array}$ & & $\begin{array}{l}\text { included; } \\
\$ 92,180\end{array}$ & & not specified & & not specified \\
\hline mechanical installation & & $\$ 1,560,000$ & & $\begin{array}{l}\text { included; } \\
\$ 414,500 \\
\end{array}$ & & not specified & & not specified \\
\hline conveyors & 14 used & & $\begin{array}{l}4 \text { used (length not } \\
\text { specified) }\end{array}$ & $\$ 300 / \mathrm{ft} * *$ & 8 used & & 4 used & \\
\hline $\begin{array}{l}\text { bag house dust } \\
\text { collection }\end{array}$ & & $\begin{array}{l}\text { included; } \\
\$ 850,000 \\
\end{array}$ & & $\begin{array}{l}\text { included; } \\
\$ 92,180\end{array}$ & & not specified & included in wood drying & $\$ 253,300$ \\
\hline storage & 30 days & & $\begin{array}{l}\text { one day silo storage } \\
\text { one week yard storage }\end{array}$ & & & not specified & one week & \\
\hline Installed cost & & $\$ 6,885,000^{*}$ & & $\$ 2,376,180^{*}$ & includes drying & $\$ 13,418,000^{*}$ & & $\$ 2,173,000$ \\
\hline WOOD DRYING & & $\$ 5,141,000^{*}$ & & $\$ 4,889,000^{*}$ & & $\begin{array}{l}\text { cost included } \\
\text { in fuel prep } \\
\text { total }\end{array}$ & $\begin{array}{l}\text { includes baghouse and } \\
\text { char combustor }\end{array}$ & $\$ 4,524,000^{*}$ \\
\hline
\end{tabular}




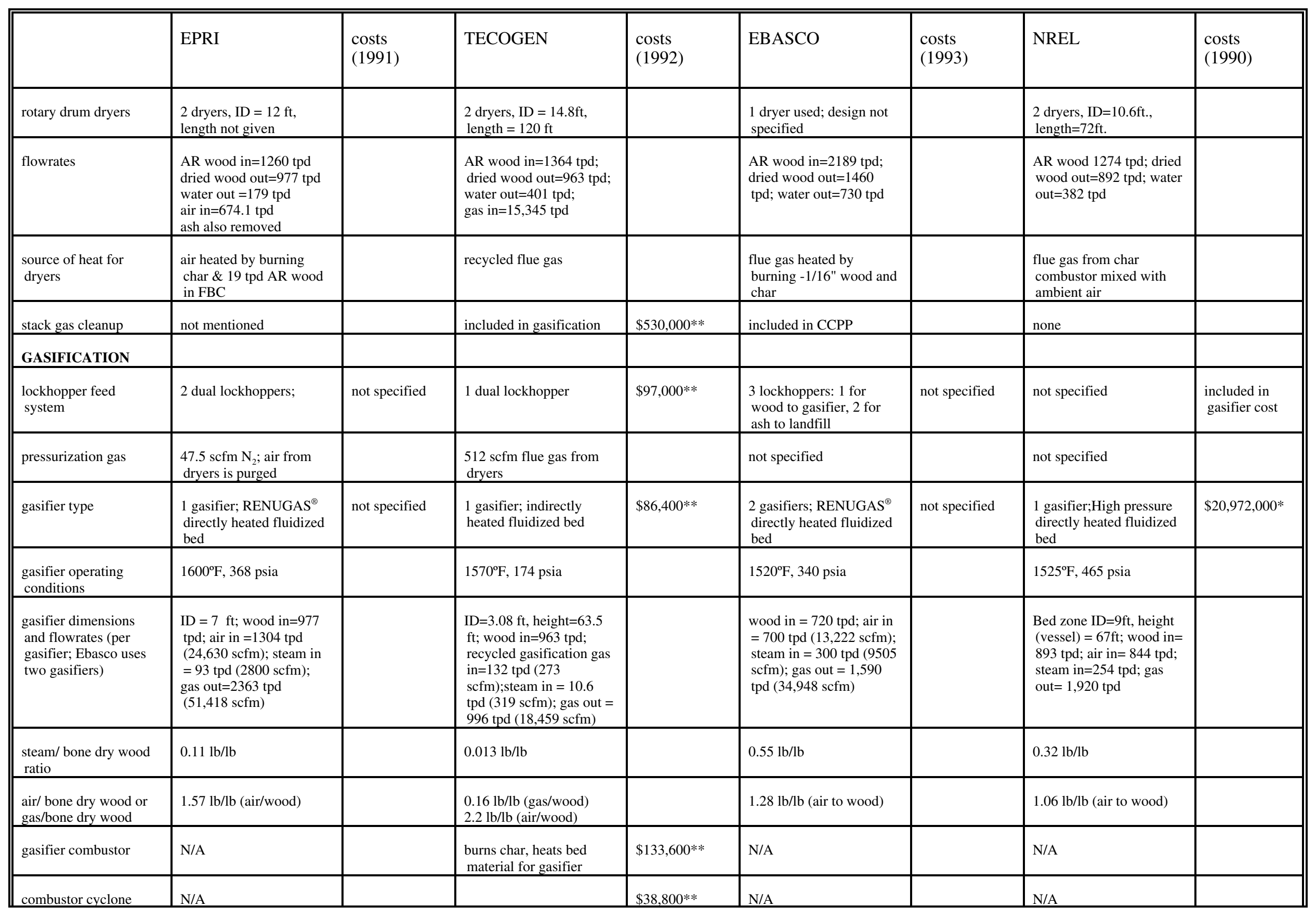




\begin{tabular}{|c|c|c|c|c|c|c|c|c|}
\hline & EPRI & $\begin{array}{l}\text { costs } \\
(1991)\end{array}$ & TECOGEN & $\begin{array}{l}\text { costs } \\
(1992)\end{array}$ & EBASCO & $\begin{array}{l}\text { costs } \\
(1993)\end{array}$ & NREL & $\begin{array}{l}\text { costs } \\
(1990)\end{array}$ \\
\hline $\begin{array}{l}\text { compressors for } \\
\text { gasifier air }\end{array}$ & & not specified & & $\$ 400,000 * *$ & & not specified & & $\$ 590,000 *$ \\
\hline air separation unit & $\begin{array}{l}\text { makes } \mathrm{N}_{2} \text { for } \\
\text { lockhoppers }\end{array}$ & not specified & not used & & not used & & not used & \\
\hline gasifier cyclones & & not specified & & $\$ 33,000 * *$ & & $\begin{array}{l}\text { included in } \\
\text { gasifier cost }\end{array}$ & & $\begin{array}{l}\text { included in } \\
\text { gasifier cost }\end{array}$ \\
\hline gasifier gas cooling & $\begin{array}{l}\text { produces saturated steam } \\
\text { at } 527^{\circ} \mathrm{F} \text { in waste heat } \\
\text { boiler }\end{array}$ & not specified & $\begin{array}{l}\text { preheats combustion air } \\
\text { in heat exchanger and } \\
\text { produces steam for } \\
\text { steam turbine in boiler }\end{array}$ & $\$ 378,000 * *$ & $\begin{array}{l}\text { produces steam for } \\
\text { gasification in heat } \\
\text { exchanger }\end{array}$ & not specified & $\begin{array}{l}\text { direct quench by water } \\
\text { injection }\end{array}$ & $\$ 15,000 *$ \\
\hline exit gas conditions & $500^{\circ} \mathrm{F}$ & & $600^{\circ} \mathrm{F}, 170 \mathrm{psia}$ & & $1000^{\circ} \mathrm{F}, 340 \mathrm{psia}$ & & $1000^{\circ} \mathrm{F}, 360 \mathrm{psia}$ & \\
\hline gas clean-up & $\begin{array}{l}\text { two scrubbing towers; } \\
\text { tars removed from water } \\
\text { in waste treatment } \\
\text { facility }\end{array}$ & not specified & $\begin{array}{l}\text { one scrubbing tower; } \\
\text { most tars separated out } \\
\text { and burned in gasifier } \\
\text { combustor }\end{array}$ & $\$ 103,000 * *$ & $\begin{array}{l}\text { ceramic candle filter } \\
\text { vessel }\end{array}$ & $\begin{array}{l}\text { cost included; } \\
\$ 2,200,000^{* *}\end{array}$ & ceramic candle filters & $\$ 2,700,000 *$ \\
\hline exit gas conditions & $120^{\circ} \mathrm{F}, 257 \mathrm{psia}$ & & $180^{\circ} \mathrm{F}, 170 \mathrm{psia}$ & & $1000^{\circ} \mathrm{F}, 340 \mathrm{psia}$ & & $1000^{\circ} \mathrm{F}, 360 \mathrm{psia}$ & \\
\hline tar usage & disposed of as waste & & $\begin{array}{l}\text { combusted to provide } \\
\text { heat to produce steam }\end{array}$ & & $\begin{array}{l}\text { allowed to remain in } \\
\text { gasification product gas; } \\
\text { combusted in gas turbine }\end{array}$ & & $\begin{array}{l}\text { cracked gasifier then } \\
\text { combusted in gas turbine }\end{array}$ & \\
\hline $\begin{array}{l}\text { gasification system } \\
\text { installed cost }\end{array}$ & & $\$ 31,900,000 *$ & & $\$ 4,592,000^{*}$ & & $\$ 16,582,000^{*}$ & & $\$ 23,687,000$ \\
\hline \multicolumn{9}{|l|}{ GAS TURBINE } \\
\hline type \& specifications & $\begin{array}{l}\text { generic model; } \\
32.2 \% \text { efficient, } \mathrm{PR}= \\
11.8 \text {; firing temp }= \\
2000^{\circ} \mathrm{F} \text {; produces } 39.7 \\
\mathrm{MW}\end{array}$ & $\$ 11,617,000^{*}$ & $\begin{array}{l}\text { General Electric } \\
\text { MS6101(B); } 31.1 \% \\
\text { efficient, } \\
\mathrm{PR}=11.8 \text {; firing temp = } \\
2020^{\circ} \mathrm{F}\end{array}$ & $\$ 13,670,000 *$ & $\begin{array}{l}\text { Westinghouse } 251 \mathrm{~B} 12 \mathrm{~A} \text {, } \\
32.5 \% \text { efficient, } \\
\mathrm{PR}=15.3 \text {; produces } 52.7 \\
\mathrm{MWe}\end{array}$ & $\begin{array}{l}\text { not specified in } \\
\text { report; } \\
\$ 12,250,000^{* *} \\
\text { ('92) from Gas } \\
\text { Turbine World } \\
\end{array}$ & $\begin{array}{l}\text { General Electric } \\
\text { LM-5000PC, 36.8\% } \\
\text { efficiency (LHV, natural } \\
\text { gas), PR=24.8 }\end{array}$ & $\$ 13,161,000^{*}$ \\
\hline gas flowrates & $\begin{array}{l}\text { fuel gas in }=54 \mathrm{lb} / \mathrm{s} \\
(51,067 \mathrm{scfm}) \text { air in }= \\
252 \mathrm{lb} / \mathrm{s}(200,000 \mathrm{scfm})\end{array}$ & & $\begin{array}{l}\text { fuel gas in=16 lb/s } \\
(16,195 \mathrm{scfm}) \text {, air } \\
\text { in=295 lb/s }(234,050 \\
\text { scfm })\end{array}$ & & $\begin{array}{l}\text { fuel gas in }=72.2 \mathrm{lb} / \mathrm{s} \mathrm{tpd} \\
(67,625 \mathrm{scfm}) \text {, air in } \\
=328 \mathrm{lb} / \mathrm{s}(259,700 \mathrm{scfm})\end{array}$ & & $\begin{array}{l}\text { fuel gas in }=51.2 \mathrm{lg} / \mathrm{s} \\
(49,912 \mathrm{scfm}), \text { air } \\
\text { in=265 lb/s }(209,819 \\
\mathrm{scfm})\end{array}$ & \\
\hline $\begin{array}{l}\text { inlet gas heat content } \\
\text { (HHV basis) }\end{array}$ & $154 \mathrm{Btu} / \mathrm{scf}$ & & $459 \mathrm{Btu} / \mathrm{scf}$ & & $132 \mathrm{Btu} / \mathrm{scf}$ & & $126 \mathrm{Btu} / \mathrm{scf}$ & \\
\hline \multicolumn{9}{|l|}{$\begin{array}{l}\text { STEAM } \\
\text { TURBINE/HRSG } \\
\end{array}$} \\
\hline steam turbine & & $\$ 3,571,000^{*}$ & includes HRSG & $\$ 7,620,000^{*}$ & & not specified & & $\$ 3,133,00^{*}$ \\
\hline
\end{tabular}




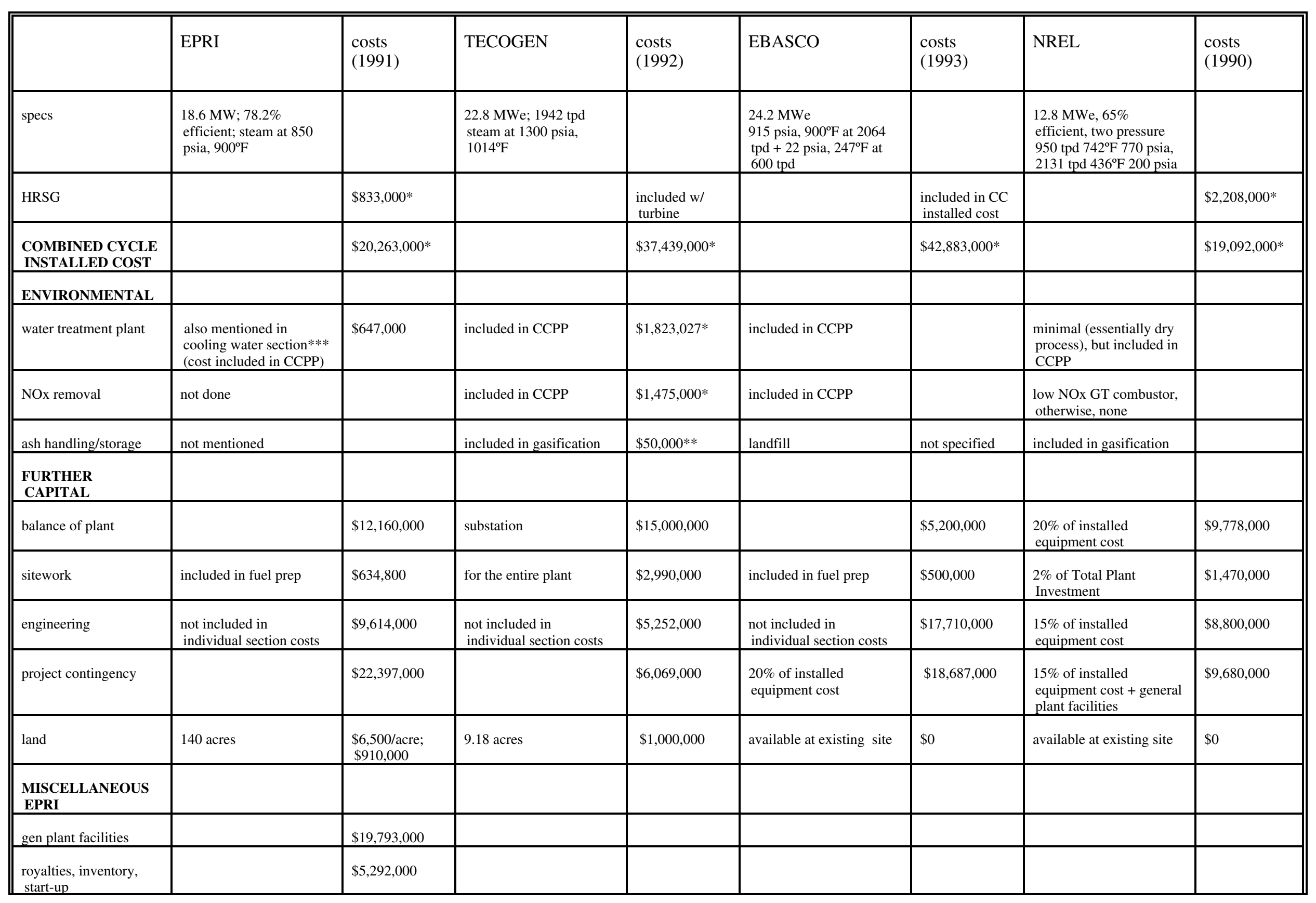




\begin{tabular}{|c|c|c|c|c|c|c|c|c|}
\hline & EPRI & $\begin{array}{l}\text { costs } \\
(1991)\end{array}$ & TECOGEN & $\begin{array}{l}\text { costs } \\
(1992)\end{array}$ & EBASCO & $\begin{array}{l}\text { costs } \\
(1993)\end{array}$ & NREL & $\begin{array}{l}\text { costs } \\
(1990)\end{array}$ \\
\hline \multicolumn{9}{|l|}{$\begin{array}{l}\text { MISCELLANEOUS } \\
\text { TECOGEN }\end{array}$} \\
\hline field expense & & & $\begin{array}{l}\text { only for gasification; } \\
\text { included in CCPP }\end{array}$ & $\$ 1,792,000$ & & & & \\
\hline $\begin{array}{l}\text { contractors fees, } \mathrm{OH} \text {, } \\
\text { profit }\end{array}$ & & & $\begin{array}{l}\text { only for gasification; } \\
\text { included in CCPP }\end{array}$ & $\$ 781,000$ & & & & \\
\hline \multicolumn{9}{|l|}{$\begin{array}{l}\text { MISCELLANEOUS } \\
\text { EBASCO }\end{array}$} \\
\hline concrete & & & & & $\begin{array}{l}\text { only for gasification; } \\
\text { included in CCPP }\end{array}$ & $\$ 1,010,000$ & & \\
\hline sales taxes on capital & & & & & $\begin{array}{l}\text { only for gasification; } \\
\text { included in CCPP }\end{array}$ & $\$ 1,260,000$ & & \\
\hline profit on construction & & & & & $\begin{array}{l}\text { only for gasification; } \\
\text { included in CCPP }\end{array}$ & $\$ 3,150,000$ & & \\
\hline $\begin{array}{l}\text { overhead and indirect } \\
\text { costs }\end{array}$ & & & & & $\begin{array}{l}\text { only for gasification; } \\
\text { included in CCPP }\end{array}$ & $\$ 5,040,000$ & & \\
\hline \multicolumn{9}{|l|}{$\begin{array}{l}\text { MISCELLANEOUS } \\
\text { NREL }\end{array}$} \\
\hline general plant facilities & & & & & & & $\begin{array}{l}\text { General Plant } \\
\text { Facilities }=10 \% \text { of } \\
\text { installed equipment cost }\end{array}$ & $\$ 5,867,000$ \\
\hline $\begin{array}{l}\text { royalties, inventory, } \\
\text { startup, spare parts, } \\
\text { working capital } \\
\end{array}$ & & & & & & & startup includes sitework & $\$ 4,936,000$ \\
\hline $\begin{array}{l}\text { TOTAL CAPITAL } \\
\text { (includes engineering } \\
\text { and contingencies) }\end{array}$ & & $\$ 141,663,000^{*}$ & & $\$ 81,939,000 *$ & & $\$ 125,440,000^{*}$ & & $\$ 88,152,000^{*}$ \\
\hline
\end{tabular}




\section{REFERENCES}

1. Mahrling, P.; Vierrath, H. (June 1989). Gasification of Lignite and Wood in the Lurgi Circulating Fluidized-Bed Gasifier. EPRI GS-6436. Frankfurt am Main, Germany. Lurgi GmbH. Available from Electric Power Research Institute, Palo Alto, CA.

2. Anderson, R. O. (1993). Ms6001FA - An Advanced Technology 70 MW-Class 50/60 Hertz Gas Turbine. Available from General Electric Company, Schenectady, NY.

3. Gas Turbine World 1992-93 Handbook (1993). Fairfield, CT: Pequot Publishing Inc.

4. Breault, R.; Morgan, D. (October 1992). Design and Economics or Electricity Production from an Indirectly Heated Biomass Gasifier. TR4533-049-92. Columbus, OH: Battelle Memorial Institute. Work performed by Tecogen Inc., Waltham, MA.

5. Wiltsee, G. A. (November 1993). Strategic Analysis of Biomass and Waste Fuels for Electric Power Generation. EPRI TR-102773. Sevenson Ranch, CA: Appel Consultants, Inc. Available from Electric Power Research Institute, Palo Alto, CA.

6. Ebasco Environmental. (October 1993). Wood Fuel Cofiring at TVA Power Plants. Contract 3407-1. Sacramento, CA: Ebasco Services Inc. Available from the Electric Power Research Institute, Palo Alto, CA.

7. Bain, R. (January, 1992). Material and Energy Balances for Methanol from Biomass Using Bioamss Gasifiers. Golden, Colorado: National Renewable Energy Laboratory.

8. Feldmann, J.; Paisley, M.A. (May 1988). Conversion of Forest Residues to a Methane-Rich Gas in a high-throughput Gasifier. Columbus, Ohio: Battelle Colubus Laboratory.

9. Weyerhauser et al. (June 1995). New Bern Biomass to Energy Project, Phase 1 Feasibility Study. NREL/TP-421-7942. Golden, CO: National Renewable Energy Laboratory. Work performed by Weyerhauser, Inc.

10. Mehrling, P. (June 1989)

11. Overend, R. P. (December 1995) Personal communication. National Renewable Energy Laboratory.

12. Anderson, R. O. (1993). MS6001FA - An Advanced Technology 70 MW-Class 50/60 Hertz Gas Turbine. Available from General Electric Company, Schenectady, NY.

13. 100-MW Nevada IGCC Operational Next Year. (July-August 1995). Gas Turbine World. pp. 30-32

14. Corman, J.C. (September 1986). System Analysis of Simplified IGCC Plants. DOE/ET14928-2233. Morgantown, WV; Morgantown Energy Technology Center. Work 
performed by General Electric Company Corporate Research and Development, Schenectady, NY.

15. Electric Power Research Institute. (June, 1993). TAG-Technical Assessment Guide. EPRI TR-102276-V1R7 Volume 1: Rev. 7. Palo Alto, CA.

16. Breault, R.; Morgan, D. (October 1992).

17. Simons Resource Consultants and B. H. Levelton and Assoc. Ltd. (December 1983). ENFOR Project C-258, A Comparative Assessment of Forest Biomass Conversion to Energy Forms. Report to Energy, Mines, \& Resources Canada. v. III pp.4-38

18. Perry, R. H.; Chilton, C.H. (1973). Chemical Engineer's Handbook. 5th Edition. New York: McGraw-Hill.

19. Gallaspy, D. T.; Johnson, T. W.; and Sears, R. E. (July 1990). Southern Company Services' Study of a KRW-Based GCC Power Plant. EPRI GS-6876. Palo Alto, CA: Electric Power Research Institute. Work performed by Southern Company Services Inc., Birmingham, AL.

20. Northern States Power et al. (May 1995). Economic Development Through Biomass Systems Integration - Sustainable Biomass Energy Production. NREL/TP-421-20517. Golden, CO. Work performed for the National Renwable Energy Laboratory and the Electric Power Research Institute by Northern States Power, Minneapolis, MN.

21. Craig, K.R., Bain, R.L., Overend, R.P., (October 1995). "Biomass Power: Where Are We, Where Are We Going, and How Do We Get There? The Role of Gasification." Proceedings of EPRI Conference on New Power Generation Technology. San Francisco, CA.

22. Craig, K.R., M.K. Mann, R.L. Bain. October 1994. "Cost and Performance Potential of Advanced Integrated Biomass Gasification Combined Cycle Power Systems." Published in ASME Cogen Turbo Power '94, 8th Congress \& Exposition on Gas Turbines in Cogeneration and Utility, Industrial and Independent Power Generation. Portland, OR. ISBN No. 0-7918-1213-8

23. Peters, M. S.; Timmerhaus, K. D. (1980). Plant Design and Economics for Chemical Engineers. 3rd Edition. New York: McGraw-Hill.

24. Peters, M.; Timmerhaus, K. (1991). Plant Design and Economics for Chemical Engineers. 4th Edition. New York: McGraw-Hill.

25. Garrett, D. (1989). Chemical Engineering Economics. New York: Reinhold. 
26. Pikulik, A.; Diaz, H. (October 10, 1977). "Cost Estimating for Major Process Equipment." Chemical Engineering; Vol. 84, [21], pp. 106-122.

27. Breault, R.; Morgan, D. (October 1992).

28. Double, J.M.; (1988) Design, Evaluation and Costing of Biomass Gasifiers. Doctoral Thesis

29. Dravo Engineering Companies. (1987). Gasification Capital Cost Estimation. Obtained from Mark Pailey in personal correspondance, August, 1994. Battelle Columbus Laboratory.

30. Weyerhauser. (1992) Gasification Capital Cost Estimation Obtained from Mark Paisley in personal correspondance, August, 1994. Battelle Columbus Laboratory.

31. Weyerhauser et al. (June 1995).

32. Battelle. (January 1993). Operation and Evaluation of an Indirectly Heated Biomass Gasifier Phase Completion Report. Contract YM-2-11110-1. Golden, CO. National Renewable Energy Laboratory

33. Perry, R. H.; Chilton, C.H. (1973).

34. Wiant, B. (September 28, 1993). Westinghouse Electric Corporation, Orlando, FL.

35. Simons Resource Consultants and B.H. Levelton and Assoc. Ltd. (December 1983). ENFOR Project C-258, A Comparative Assessment of Forest Biomass Conversion to Energy Forms. Report to Energy, Mines, \& Resources Canada. V. III p.4-38 Table 4-7.

36. Levelton, B.H., Sawmill and Small Scale Combustion Systems, Published in Proceeding of Energy Generation and Co-Generation from Wood. p. 80-26.

37. Ebasco Environmental. (October 1993).

38. Gas Turbine World 1992-93 Handbook (1993). Fairfield, CT: Pequot Publishing Inc.

39. Corman, J.C. (September 1986).

40. Esposito, N. T. (June 1990). A Comparison of Steam-Injected Gas Turbine and Combined Cycle Power Plants: Technology Assessment. EPRI GS-2387-4. Palo Alto, CA: Electric Power Research Institute. Work performed by Jersey CP\&L, Morristown, NJ.

41. Ibid.

42. Ibid. 
43. Wiltsee, G. A. (November 1993).

44. Corman, J.C. (September 1986).

45. Electric Power Research Institute. (September 1985). TAG - Technical Assessment Guide. EPRI P-6587-L Volume 1. Palo Alto, CA.

46. Ibid.

47. Turnure, J.T.; Winnet, S.; Shackleton, R.;Hohenstein, W.; (1995). "Biomass Electricity: Long-Run Economic Prospects and Climate Policy Implications". Second Biomass Conference of the Americas Proceedings; August 21-24, 1995, Portland, OR. NREL/CP-200-8098. Golden, CO: National Renewable Energy Laboratory; pp. 14181427.

48. P. Elliott, and R. Booth. (1993). “Brazilian Biomass Power Demonstration Project.” Special Project Brief. Shell International: London, U.K.

49. Northern States Power (May 1995).

50. Weyerhauser et al. (June 1995).

51. Marrison, C. I. and Larson, E. D., (August 1995). “Cost Versus Scale for Advanced Plantation-Based Biomass Energy Systems in the U.S.A. and Brazil." Second Biomass Conference of the Americas Proceedings; August 21-24, 1995, Portland, OR. . NREL/CP-200-8098. Golden, CO: National Renewable Energy Laboratory; pp.12721290.

52. Wiltsee, G. A. (November 1993).

53. Ebasco Environmental. (October 1993).

54. Gallaspy, D. T.; Johnson, T. W.; and Sears, R. E. (July 1990).

55. Gas Turbine World 1992-93 Handbook (1993).

56. Peters, M.; Timmerhaus, K. (1991).

57. Gmeindl, F. D.; Geisbrecht, R. A.; Craig, K. R.; Kasper, S.; Shah, V. B. (June 1989). "New Directions in MCFC Systems." Proceedings of the Ninth Annual Gasification and Gas Stream Cleanup Contractors Meeting. DOE/METC--89/6107. Morgantown, WV: Morgantown Energy Technology Center. 
43. Wiltsee, G. A. (November 1993).

44. Corman, J.C. (September 1986).

45. Electric Power Research Institute. (September 1985). TAG - Technical Assessment Guide. EPRI P-6587-L Volume 1. Palo Alto, CA.

46. Ibid.

47. Turnure, J.T.; Winnet, S.; Shackleton, R.;Hohenstein, W.; (1995). "Biomass Electricity: Long-Run Economic Prospects and Climate Policy Implications". Second Biomass Conference of the Americas Proceedings; August 21-24, 1995, Portland, OR. NREL/CP-200-8098. Golden, CO: National Renewable Energy Laboratory; pp. 14181427.

48. P. Elliott, and R. Booth. (1993). "Brazilian Biomass Power Demonstration Project." Special Project Brief. Shell International: London, U.K.

49. Northern States Power (May 1995).

50. Weyerhauser et al. (June 1995).

51. Marrison, C. I. and Larson, E. D., (August 1995)."Cost Versus Scale for Advanced Plantation-Based Biomass Energy Systems in the U.S.A. and Brazil." Second Biomass Conference of the Americas Proceedings; August 21-24, 1995, Portland, OR. . NREL/CP-200-8098. Golden, CO: National Renewable Energy Laboratory; pp.12721290.

52. Wiltsee, G. A. (November 1993).

53. Ebasco Environmental. (October 1993).

54. Gallaspy, D. T.; Johnson, T. W.; and Sears, R. E. (July 1990).

55. Gas Turbine.World 1992-93 Handbook (1993).

56. Peters, M.; Timmerhaus, K. (1991).

57. Gmeindl, F. D.; Geisbrecht, R. A.; Craig, K. R.; Kasper, S.; Shah, V. B. (June 1989). "New Directions in MCFC Systems." Proceedings of the Ninth Annual Gasification and Gas Stream Cleanup Contractors Meeting. DOE/METC--89/6107. Morgantown, WV: Morgantown Energy Technology Center. 
Public reporting burden for this collection of Informallon is estimaled to average 1 hour per response, including the time for reviewing instructlons, searching existing data sources, gathering and malntaling the data neoded, and comploting and roviowing the collection of informatlon. Send comments regarding this burdon ostimate or any other aspoct of this collection of Information, Including suggestions for reducing this burden, to Washington Headquarters Services, Directorate for Iniormation Operatlons and Reports, 1215 Jefferson Davis Hllghway, Sulte 1204, Arlington, VA 22202-4302, and to the Office of Management and Budget, Paperwork Reduction Project (0704-0188), Washington, DC 20503.
1. AGENCY USE ONLY (Leave blank)
2. REPORT DATE January 1996
4. TITLE AND SUBTITLE
Cost and performance analysis of biomass-based integrated gasification combined cycle (BIGCC) power systems

6. AUTHOR(S)

K.R. Craig and M.K. Mann

\author{
7. PERFORMING ORGANIZATION NAME(S) AND ADDRESS(ES) \\ National Renewable Energy Laboratory \\ 1617 Cole Boulevard \\ Golden, Colorado 80401
}

\section{REPORT TYPE AND DATES COVERED}

\section{FUNDING NUMBERS}

BP61.1717

\section{SPONSORING/MONITORING AGENCY NAME(S) AND ADDRESS(ES)}

National Renewable Energy Laboratory

1617 Cole Boulevard

Golden, Colorado' 80401

8. PERFORMING

ORGANIZATION REPORT

NUMBER

10.

SPONSORING/MONITORING AGENCY REPORT NUMBER

TP-430-21657

DE96013105

\section{SUPPLEMENTARY NOTES}

\section{2a. DISTRIBUTION/AVAILABILITY STATEMENT}

National Technical Information Service

U.S. Department of Commerce

5285 Port Royal Road

Springfield, VA 22161 12b. DISTRIBUTION CODE

UC. Category: 1311

13. ABSTRACT (Maximum 200 words) Electric power production from biomass can contribute to the power mix in the United States. This report describes the cost and performance potential of three biomass-based integrated gasification combined cycle (IGCC) systems--high-pressure air blown, low-pressure air blown, and high-pressure indirectly heated. Advanced technology and an " $n^{\text {thx }}$ plant basis for costing are assumed. Excess process heat from the gasification and gas turbine sections produced steam for a two-pressure steam cycle system. Gas was cleaned before the gas combustor by a tar cracker and either a direct quench and conventional particulate-removal operation (for the low-pressure systems) or by a hot ceramic candle filter unit (for the highpressure system). Detailed ASPEN process simulations of the systems were used to design, size, and cost the major plant equipment sections. Literature references and previous biomass and coal studies provided overall plant cost information. Standard economic analyses were performed to determine the levelized cost of electricity produced by each system. Alternative design and operating conditions were tested to optimize plant efficiency and reduce cost of electricity. In total, the economic viability and efficiency of biomass-based IGCC generation technology appear quite attractive.

14. SUBJECT TERMS

Biomass power; gasification; high-pressure air blown gasifier; low pressure air blown gasifier; low pressure indirectly heated gasifier; economics of biomass-based IGCC; efficciency of biomass-based IGCC
15. NUMBEA OF PAGES

16. PRICE CODE

\section{SECURITY \\ CLASSIFICATION OF REPORT}

\author{
18. SECURITY \\ CLASSIFICATION \\ OF THIS PAGE
}

\begin{tabular}{l|l}
\hline $\begin{array}{l}\text { 19. SECURITY } \\
\text { CLASSIFICATION } \\
\text { OF ABSTRACT }\end{array}$ & $\begin{array}{l}\text { 20. LIMITATION OF } \\
\text { ABSTRACT }\end{array}$ \\
\end{tabular}

